\title{
The Rise and Fall of Swiss Unemployment \\ Relative Demand Shocks, Wage Rigidities, and Temporary Immigrants
}

\author{
Patrick A. Puhani ${ }^{\#}$ \\ SIAW, University of St. Gallen; IZA, Bonn; CEPR, London \\ Swes ingtitute for International Economics \\ and Aopled Economic Resecroch \\ University of St.Gallen
}

January 2003

JEL classification: E24, J21, J31, J64

Keywords: earnings, non-employment, rigidity, identification, foreigners, work permits

Dr. Patrick A. Puhani

University of St. Gallen

SIAW, Room 129

Dufourstr. 48

CH-9000 St. Gallen

Switzerland

Phone: $\quad++41-71-2242341$

Fax: $\quad++41-71-2242298$

E-Mail: Patrick.Puhani@unisg.ch

URL: $\quad$ www.siaw.unisg.ch/puhani

\footnotetext{
\# The author is also a Research Fellow of the William Davidson Institute at the University of Michigan Business School, Ann Arbor, MI, U.S.A.
} 


\section{Non-Technical Summary}

Switzerland, traditionally a 'zero unemployment' economy, has seen an unprecedented rise in joblessness in the 1990s. However, unlike, for example, in western Germany during the same period Swiss unemployment fell again to a rather low level after 1997. This paper uses microdata to test whether Switzerland has experienced similar negative relative demand shocks for lowskilled workers as documented for other western countries during the end of the 20th century. Because the high unemployment period was rather short, I test whether the Swiss wage structure has reacted flexibly to potential shocks. Swiss labour market institutions are more similar to those of the US than to those of most continental European economies and one may thus expect an absence of wage rigidities for institutional reasons (e.g. trade unions). Another feature of the Swiss labour market is its high share of immigrants (around 20 per cent). Switzerland issues among others - temporary annual work permits which may be used to control labour supply. Therefore, this paper also tests whether the skill structure of temporary workers in Switzerland was adjusted to relative demand shocks.

My findings are the following: First, the Swiss labour market experienced a negative net demand shock against low-skilled workers in the 1990s. However, this applies only to those workers who do not have an apprenticeship certificate. The Swiss apprenticeship system is similar to the German one. Thus, the evidence in this paper supports evidence by Freeman and Schettkat (2000) that low-skilled US Americans (workers with a high school degree) have a lower level of skill than those holding a German-style apprenticeship certificate. The secular relative demand shock against the 'low skilled' in the US literature refers to workers with a high school certificate or less. Switzerland, however, provides a large group of workers with apprenticeship training, so that workers with an educational level below apprenticeship are a much smaller group in Switzerland than the 'low skilled' in the United States. This is one potential explanation why Switzerland was able to prevent wage inequality increases like in the US.

My second result is that relative wages for the least skilled (without even apprenticeship training) have not fallen in face of a negative relative net demand shock. Although trade unions are by far not as strong in Switzerland as in Germany, there is some evidence from the Swiss Federal Statistical Office (Bundesamt für Statistik, 2002) which shows that between 1999 and 2001 the average collectively bargained minimum wages (German: Gesamtarbeitsvertragliche Mindestlöhne) for unqualified workers rose by 7 percent whereas those of qualified and highly qualified workers rose by about 3 percent. In the light of my results, this gives credence to the view that these union policies generated an unemployment-causing wage rigidity for the very low skilled in Switzerland. Although this result may be surprising given the decentralised Swiss wage bargaining system, it might be explained by a public debate on minimum wages which became especially prominent towards the end of the 1990s. Public debate may co-ordinate wage demands even in a decentralised system.

Third, I find some evidence that the share of temporary immigrant workers was reduced among the low-skilled group when Swiss unemployment was at its peak. By the year 2001, the relative temporary immigrant worker share among the low skilled had increased again, though. Hence, adjustment of the skill mix of immigrants with an annual work permit to the relative demand shocks against this group seems to have been only temporary, whereas the wage rigidity and increase in relative unemployment incidence persisted for workers with education below apprenticeship. 


\begin{abstract}
Switzerland, traditionally a 'zero unemployment' economy, has seen an unprecedented rise in joblessness in the 1990s although unemployment fell again to a rather low level after 1997. This paper tests whether Switzerland experienced a negative relative net demand shock against the low skilled (like the US) during this period. It turns out that only workers with an educational level below apprenticeship were affected by such a shock. Furthermore, I test whether wages reacted flexibly to this shock and find that they were rigid, which can explain the relative unemployment increase for this group. Finally, I test whether the skill mix of temporary immigrants was adjusted to the relative demand shock. The evidence suggests that it was changed during the period around 1997 when unemployment peaked. By 2001, however, the educational mix of temporary immigrants was not significantly different from its 1991 level any more, although relative unemployment for the least skilled was still relatively high in face of the relative wage rigidity affecting this group.
\end{abstract}

Acknowledgement: This research was supported by the Volkswagen Foundation and the Swiss National Science Foundation (SNF) under the National Research Programme NFPNR 45 with proposal number 4045-059673. Many thanks also go to IZA, Bonn, for supporting this project. The work on this paper was done during my leave during the 2001/2 academic year in the Economics Department at MIT, whose hospitality and support are gratefully acknowledged.

I am grateful to Daron Acemoglu, Yves Ammann, Joshua Angrist, David Autor, Peter Balastair, Thomas Bauer, Daniel M. Bernhofen, Hielke Buddelmeyer, Donald Cox, Christopher Foote, Richard B. Freeman, Markus Frölich, Caroline M. Hoxby, Ira Gang, Michael Gerfin, Peter Gottschalk, Heinz Hauser, Wayne Gray, Lawrence F. Katz, Gebhard Kirchgässner, Winfried Koeniger, Michel Kolly, Astrid Kunze, Valérie Lässig, Michael Lechner, Stephen Machin, Hans Mangold, Blaise Melly, Ulrich Müller, Gerard Pfann, Steve Pischke, Hedwig Prey, Jeff Smith, Alfred Schmutz, Heidi Steiger, Bernhard A. Weber, Klaus F. Zimmermann, and seminar participants at Boston College, Clark University, Harvard University, the Institute for the Study of Labor (IZA), MIT, and the $10^{\text {th }}$ International Conference on Panel Data in Berlin 2002, for helpful comments. All remaining errors are my own. 


\section{Introduction}

Rising wage inequality or rising unemployment in many industrialised countries has attracted the attention of both professional economists and the general public. There is a consensus among labor economists that wage inequality increased significantly in the United States from the mid 1970s to the mid 1990s. The same is true for the United Kingdom in the 1980s (cf. Katz and Autor, 1999). Whereas both these countries have seen a trend decline in unemployment in the last two decades, the experience of many continental European countries has been rather different, with many experiencing an increase in the unemployment rate. As there is also a broad consensus among the labour economics profession that rising US wage inequality is related to rising returns to skill mostly due to skill-biased technological change (cf. Acemoglu, 2002b), Krugman (1994) has formulated the hypothesis that rising continental European unemployment and rising US wage inequality are 'two sides of the same coin' (p. 37), namely the fall in the relative demand for low-skilled labour. However, there is little empirical evidence on this hypothesis, as studies on the issue on non-Anglo-Saxon economies are rare (for exceptions see Blau and Kahn, 1996; Gottschalk and Joyce, 1998; Kahn, 2000; Acemoglu, 2002a).

This paper tests Krugman's hypothesis for Switzerland in the 1990s. Having had virtually zero unemployment for most of the post-war period, after 1991 unemployment rose to levels Switzerland has not experienced since the 1930s when the unemployment rate was first recorded ( $c f$. Figure 1, see also Flückiger, 1998). However, after 1997, the unemployment rate declined again. Figure 1 shows that the employment rate changed in a similar fashion as the unemployment rate (note that these two rates are based on different risk sets). The trend break and decline in the employment rate demonstrates that the rise in Swiss unemployment is 
not purely related to measurement issues. ${ }^{1}$ Macroeconomic factors like monetary policy may provide an explanation for the surge in joblessness ( $c f$. Section 2). Nevertheless, the Krugman hypothesis raises the question whether Switzerland's unemployment experience can be related to its wage structure. Given that around 19 percent of the population in Switzerland are immigrants, however, it is also necessary to ask whether the flexible system of temporary work permits was not used to accommodate demand shocks against the low skilled.

Although Switzerland is a small continental European economy, it has some interesting institutional features. Switzerland has taken a very conservative, indeed defensive, approach towards socialist labour market regulations which many European countries enacted in the 1970s. The Swiss labour market institutions are thus very flexible and in some sense resemble more those of the Anglo-Saxon countries than continental European systems like France or Germany (OECD, 1996a; b). Also, Switzerland is a very open economy with about 70 percent of GDP related to trade (Penn World Tables). Its GDP per capita is among the highest in Europe and slightly above the one of the United States (in US dollars in 1999, United Nations).

What distinguishes Switzerland from the United States and Britain, however, is that it operates an apprenticeship training system very similar to the one of Germany. One can hence expect that its skill structure at the lower end of the distribution resembles Germany more than the United States. Freeman and Schettkat (2000) show that low-skilled Germans with apprenticeship training have a higher level of human capital than low-skilled Americans. Hence, a finding of no relative negative demand shock against Swiss workers with only apprenticeship training would support the view that the Swiss/German-style vocational education system can achieve more wage equality in a flexible labour market.

\footnotetext{
${ }^{1}$ Since 1991, the official unemployment rate is based on International Labour Office (ILO) definitions. There was, however, no definition change concerning the employment rate in Figure 1.
} 
Microeconometric work on Swiss unemployment in the 1990s is fairly rare. There are papers trying to explain unemployment duration or incidence in relation to benefit entitlement, social norms or active labour market policies ( $c f$. Stutzer and Lalive, 2001; Gerfin and Lechner, 2002; Lalive, van Ours, and Zweimüller, 2002a; 2002b). Flückiger (1998) estimates that both the permanent and non-permanent resident workforce of Switzerland became less responsive to the economic cycle in the late 1980s and early 1990s and concludes that immigration policy as well as increased female labour supply account for this fact. A paper more related to my question is the one by Fehr and Goette (2000). Although these authors are mainly interested in nominal wage rigidity, they provide evidence that nominal wage rigidities are correlated with unemployment rates across Swiss regions and industries. To the best of my knowledge, Fehr and Goette (2000) provide the only study so far which addresses the issue of real wage rigidity in Switzerland using individual data. However, their empirical approach is based on a structural model that estimates the real effects of nominal wage rigidity. As Fehr and Goette (2000) have a rather different focus than this paper, they are also not addressing the question of relative demand shocks against the low skilled and do not test the Krugman hypothesis.

Section 2 provides a brief introduction to Swiss labour market institutions during the 1990s. The timing of institutional changes described there will be important for the identification strategy in the empirical part of the paper. Data sets used in this study are discussed in Section 3. Section 4 offers a macroeconomic picture of the Swiss labour market in the 1990s by focusing on the relative demand and supply of skills. Only high- and lowskilled groups are distinguished in this section. It is shown that both the relative demand and supply of high- versus low-skilled workers rose during the 1990s, but that the relative supply increase slightly accelerated after 1997, when unemployment started to decrease. Although there is some weak indication for relative wage rigidity, relative supply changes have played the key role in preventing sharp rises in the skill premium between 1991 and 2001. 
Simulations further suggest that the effect of low-skilled temporary work permit holders on the skill premium is small. However, the macro approach taken in this section relies on strong assumptions. Therefore, an alternative approach to investigating wage rigidities on the basis of micro data is provided in Section 5. Here I distinguish between various skill categories in the age and education dimensions and find a relative wage rigidity for workers with an education below apprenticeship level. It is also shown that the share of workers with an annual work permit in this education group was reduced temporarily when unemployment was at its peak in Switzerland. In sum, the results suggest that the German-style Swiss vocational education system shielded a large part of low-skill workers from the relative demand shocks experienced by high school graduates in the United States. However, despite the flexilibity of the Swiss labour market institutions in principle, relative net demand shocks combined with public debate on whether to install minimum wages seem to have affected union wage pressure ( $c f$. Section 2) which led to an increase in the relative unemployment likelihood of workers without any vocational education. Section 6 concludes.

\section{Institutional Background}

This section describes key institutional aspects potentially affecting the analysis of the paper. A lot of the following information is drawn from OECD (1996b). The Swiss labour market has the interesting institutional feature that it is very flexible in terms of employment regulations (more like the US than Germany) but operates a vocational training system very similar to the one of Germany. To illustrate how deregulated the Swiss labour market is, note that mandatory unemployment insurance was only introduced transitorily in 1977 , to be made permanent in 1983 (SECO, 2002). OECD (1993) employment protection indicators rank Switzerland among the least regulated labour markets, closer to the US than Germany or France. Also collective bargaining coverage is much lower than in Germany or France, which have coverage rates above 90 percent as opposed to 50 percent for Switzerland in 1994 
(OECD, 1997). Moreover, collective bargaining is very decentralised (much more than in Germany). Swiss collective bargaining agreements may bind a whole industry nationwide, but may also just cover an industry in a region or only a single company. The OECD (1996b) reports results from a survey suggesting that only 72 percent of workers covered by collective bargaining were also affected by wage agreements, which substantiates the view of flexible and decentralised wage bargaining in Switzerland. Initiatives for reductions of weekly working hours as implemented in Germany or France were rejected by the Swiss people in popular votes in 1988 and again in 2002 (www.admin.ch).

However, unions manage to fix minimum wage agreements in many sectors and a recent study by the federal statistical office suggests that minimum wages were pushed up on average by 7 percent for workers without even an apprenticeship qualification between 1999 and 2001 whereas the minimum wages of workers with qualifications increased by only 3 percent on average (Bundesamt für Statistik, 2002). This development occured at the same time when the public debate on the formal introduction of minimum wages was sparked off by union demands (Swiss Federation of Trade Unions, 2000). ${ }^{2}$ Hence, despite of the general flexibility of the decentralised Swiss labour market, it seems that unions are able to effect some wage compression and centralisation through public debate. Whether higher relative wages for the low skilled are related to higher relative unemployment for this group is an empirical question, however, which I will address on the basis of individual data in Section 5 of this paper.

Figure 2 substantiates the view that Swiss wages do on average exhibit some flexibility. It shows GDP growth per capita, wage growth (measured by the OECD as hourly manufacturing wages) and the unemployment rate during the 1990s. The Swiss recession lasted for more than half a decade, but real wage growth remained below GDP growth per capita in all years of the 1990s except one. Yet despite the decline in real wages at the 
beginning of the 1990s in Switzerland, unemployment and non-employment increased. In this period, Switzerland experienced a prolonged recession, which was associated with high real interest rates (the average overnight real interest rate was $-2.50,1.00,2.74$, and 0.79 percent in the early 1980s, late 1980s, early 1990s, and late 1990s, respectively, according to author's calculations from Swiss National Bank data available on www.snb.ch/d/index3.html). In addition, the Swiss labour market experienced a slightly higher rate of restructuring in the 1990s than in the late 1980s. Restructuring index calculations by the author based on the changes in employment shares of 16 sectors (as reported by the Federal Statistical Office's BESTA archive) reveal indices of $0.17,0.25$, and 0.21 for the late 1980 s, early 1990 s, and late 1990s, respectively. The index states how many percent of employees changed sector during one quarter (agriculture is not included in the BESTA archive). However, restructuring was higher in the early 1980s (at 0.37) due to the aftermath of the second oil shock.

The macroeconomic environment may give some explanation for why the (by Swiss standards) sharp rise in unemployment from virtually 0 to slightly over 5 percent (and the fall in the employment rate from 65.3 to 62.5 percent) in the early 1990s produced unemployment statistics last seen in the 1930s ( $c f$. Figure 1). ${ }^{3}$ After 1997, the unemployment rate decreased again to around 2 percent (during this period, real interest rates decreased, restructuring abated, and growth picked up again).

These unemployment changes started an active period of labour market policy reforms. It may be alleged that unemployment figures are affected by the generosity of unemployment benefits. Therefore, the timing of these reforms is important for judging the identification strategy in Section 5 of this paper, which is based on the measurement of unemployment incidence over time. Here, I outline some of the major changes that were

\footnotetext{
${ }^{2}$ Informal minimum wages exist through collective bargaining contracts.

${ }^{3}$ See also Weber, 2001, on the Swiss labour market in the 1990s; Flückiger, 1998, for a discussion of labour market developments in Switzerland since the mid 1970s; and Schmid, 1998, for a discussion of Swiss unemployment in the $20^{\text {th }}$ century.
} 
made. On the $1^{\text {st }}$ of April 1993, a significant increase in the maximum eligibility period was enacted from $85 / 170 / 250$ to $170 / 250 / 400$ days for people who had contributed 6/12/18 months to the insurance fund. But the reform also reduced the replacement ratio from 80 to 70 percent for most people (SECO, 2002, and communication with SECO per email). On the whole, the system was made more generous in face of the increasing unemployment problem. However, from 1995 onwards, the system became more stringent again. There were small reforms of the benefit system in every single year between 1995 and 2002 that are not important for the purposes of this paper, though. The interested reader can follow up the links on the internet web site www.seco-admin.ch/ or request the SECO (2002) mimeograph from the author.

One explanation put forward for why Swiss unemployment has been very low in the past is the flexible system of work permits that Switzerland operates ( $c f$. Liebig, 2002, on Swiss immigration policy). The main categories of immigrant workers are frontier persons (G-permit), who are nor allowed to stay overnight in Switzerland, seasonal workers (Apermit), who must not stay in Switzerland for longer than 9 months per year and have to get their permit renewed every year, annual (B-permit) workers, who have to get their permit renewed until they receive almost automatically a permanent $(\mathrm{C})$ residence permit after five or ten years in the country (depending on their nationality). The share of permanent $(\mathrm{C})$ residents among resident (B and C) immigrants increased from 28 percent in 1960 to 37, 77, 75, and 75 percent in 1970, 1980, 1990, and 2000, respectively (Bundesamt für Ausländerfragen, 2000). This has also been documented by the OECD (1996b) and Flückiger (1998), where evidence is provided that both the permanent and non-permanent workforce were less elastic to shocks in the late 1980s / early 1990s than in the 1970s / early 1980s. Since 1988, there have been 4 popular votes initiated by right-wing groups to limit the share of immigrants in the population, which is currently around 19 percent. All these initiatives have been rejected by the Swiss people (although the vote on limiting the number of asylum seekers in 2002 was very close), but so has been a government proposal for 'easier naturalisation of young immigrants' in 
1994. In the same year, the Swiss people also accepted a proposal for 'forceful measures in immigrant law' (details on all these popular votes can be found in French and German on the internet page www.admin.ch). These popular votes demonstrate that immigration is an important and topical issue in Switzerland. Therefore, the investigation of wage and unemployment structures in this paper will be complemented by an analysis of the potential labour supply effects generated by variations in the immigrant population. I will focus on the effect of aliens on the skill structure and test whether the relative share of temporary immigrants was adjusted to relative net demand shocks in the labour market. This question is interesting from a policy point of view, as temporary work permits exist also for the purpose of allowing some labour supply fine tuning.

\section{Data}

I mainly use the Swiss Labour Force Survey (SLFS, abbreviated SAKE in German, ESPA in French), which is a representative survey of permanent residents of Switzerland (see http://www.statistik.admin.ch/stat_ch/ber03/sake/etfr03.htm for more information on the SLFS). The SLFS is the only generally available micro data source for the 1990s which is representative for the population of residents of Switzerland (which includes immigrants with B and C permits). It was started in 1991 and has been continued annually since then. ${ }^{4}$ Only people aged 16 to 65 are included in the sample. Apprentices are excluded in the wage samples, because the hours worked in the firm information is not consistently available for the whole observation period. So are self-employed workers, because it is unclear how much of their income is attributable to human versus physical capital. The wage variable is earnings divided by normal hours worked. The labour force status is classified according to the definition of the International Labour Office, which demands a person not to be working,

\footnotetext{
${ }^{4}$ Table B1 in Appendix B reports sample sizes for the years 1991 to 2001.
} 
searching for work and to be ready to take up work in the very short term in order to be regarded as unemployed.

Furthermore, all analyses will be carried out using the cross-sectional weights provided in the SLFS by the Swiss authorities. Table A1 in Appendix A provides summary statistics (taking weights into account) for the labour force samples (as used in the unemployment regressions in Section 5). ${ }^{5}$ Wages are adjusted by the consumer price index to year 2000 Swiss francs. As to the labour market characteristics, dummy variables are used to define age, highest educational attainment, gender, and regional categories. Age is used as a proxy for experience. For readers familiar with the Swiss education system, higher education includes Universität and Hochschule; higher vocational education subsumes any type of Fachschule plus the Meister degree; advanced high school denotes Matura; apprenticeship consists of Diplommittelschule plus any type of Lehre (apprenticeship) except Anlehre (low profile apprenticeship). People with only Anlehre (low profile apprenticeship), any other form of education, mandatory school, or no formal degree at all are subsumed under the education category mandatory school or less. Note that from 1996 onwards, there was a slight coding change in that 'other form of education' was excluded as a possible answer to the education question. However, I will argue in Section 5 that my results are not driven by this fact.

Region is classified according to which language is spoken in the canton (Swiss political subunit). Although Switzerland is a rather small country (slightly less than twice the size of New Jersey in area with a population of slightly more than 7 million people; www.cia.gov/cia/publications/factbook/index.html), labour markets are still somewhat segregated between the three largest language groups (German, French, and Italian). In some cantons, more than one language is spoken, so for Fribourg, Valais, and Vaud, I allocate people to the French or German region according to their mother tongue. The same is true for

\footnotetext{
${ }^{5}$ Table B2 and Table B4 in Appendix B display summary statistics for the samples used in the wage and nonemployment regressions in Section 5, respectively. The same samples are used in Section 4.
} 
Grigione, where people are allocated to the German or Italian part of Switzerland according to their native language (Rumantsch people are allocated to the German part). The French and Italian parts are subsumed under the category 'Latin', as sometimes done in Switzerland (there are not that many observations - especially on immigrants - for the rather small Italian part of Switzerland in the sample). Shares of temporary work permit holders (B immigrants) by subgroup are shown in Table A2 in Appendix A. ${ }^{6}$

In addition to the Swiss Labour Force Survey, I make use of the so-called Swiss Wage Structure Survey (WSS), which is a survey of employers (for information in German, French, or Italian, see the internet page http://www.statistik.admin.ch/stat_ch/ber03/lohn/dtfr03.htm). Although the WSS is very large with around 500,000 observations, it also has some drawbacks. First, I received data only from the private sector. Second, about 17 percent of the observations have no information on education, which is a key variable for my purposes. Third, the survey refers only to wage earners and thus is neither representative for the labour force nor the population (no non-employed persons are included). Fourth, workers who may appear in two different waves are not identifiable due to lack of a person identifier. Fifth, the survey started only in 1994 and is bi-annual. Nevertheless, data from this survey may serve as a useful sensitivity check for changes in the Swiss wage structure since $1994 .^{7}$

\footnotetext{
${ }^{6}$ Table B5 and Table B6 in Appendix B provide unemployment and non-employment rates for various socioeconomic subgroups.

${ }^{7}$ Table B3 in Appendix B reports means for the WSS samples. Comparing these with the ones of the SLFS in Table B2 reveals a similar age and regional structure, but differences in the education and gender shares. The latter probably stems from the fact that the public sector is excluded from the data set available to me (it is not possible to form a private sector sample from the SLFS that corresponds to the WSS sample selection). The former may also be related to this issue, but the just mentioned high number of missing answers in the education variable may also play a role. Note that the wage variable in the WSS is full-time equivalent gross monthly earnings (a variable that has already been created by the statistical office).
} 


\section{The Macro Picture: Relative Supply and Demand Changes and Immigrant Workers}

This section provides a first overview of changes in the relative supply and demand for skills in the Swiss labour market in the 1990s using data from the SLFS. Katz and Murphy (1992) have among others documented the secular increase in the relative demand for high- versus low-skilled labour in the United States. Although the relative supply of high-skilled labour increased, relative demand outpaced the supply increase, which can explain the rising skill premium in the US in the 1980s and mid 1990s (for a survey, see Acemoglu, 2002b). In this section, I apply the framework used in Katz and Murphy (1992) and Autor, Katz, and Krueger (1998) in order to describe relative demand and supply changes in the Swiss labour market. Furthermore, in an extension to this framework, I simulate the degree of relative wage rigidity and the contribution of immigrants to the skill premium. Although what follows relies on strong assumptions, this analysis within a model frequently applied in the literature is useful to provide a rough picture of relative supply and demand for skill changes during an exceptional period for the Swiss labour market.

Following Katz and Murphy (1992), Autor, Katz and Krueger (1998) and Acemoglu (2002a), I take the constant elasticity of substitution (CES) production function as a modeling framework

$$
Y_{t}=\left[\left(A_{l t} L_{t}\right)^{\rho}+\left(A_{h t} H_{t}\right)^{\rho}\right]^{(1 / \rho)},
$$

where $A_{h}$ and $A_{l}$ indicate high- $(H)$ and low skill $(L)$ augmenting technology, respectively, and $t$ is a time indicator. Assuming firms are on their relative demand curve, the following relationship must hold (which is the implicit relative demand function):

$$
\ln \left(\frac{w_{h t}}{w_{l t}}\right)=\left(\frac{1}{\sigma}\right)\left[\ln \left(\frac{A_{h t}}{A_{l t}}\right)^{\sigma-1}-\ln \left(\frac{D_{h t}}{D_{l t}}\right)\right],
$$


where I will assume the elasticity of substitution $\sigma$ to be either $1,1.4$, or 2 (cf. Katz and Murphy, 1992; Autor, Katz and Krueger, 1998; or Acemoglu, 2002a). $D_{h}$ and $D_{l}$ are demanded quantities of labour types $H$ and $L$, respectively. Under these assumptions, one can estimate the relative demand index $\ln \widehat{\left(\frac{A_{h t}}{A_{l t}}\right)^{\sigma-1}}$ by observing relative wages $\ln \left(\frac{w_{h t}}{w_{l t}}\right)$ and relative employment $\ln \left(\frac{D_{h t}}{D_{l t}}\right)$. In order to create a benchmark for the simulation of wage rigidities, I invoke the assumption that relative supply is inelastic and changes in relative supply equal changes in the relative population of the two skill groups, $\ln \left(\frac{S_{h t}}{S_{l t}}\right) \cdot{ }^{8}$ Although this assumption may seem strong, it is plausible for a simulation exercise, as it only refers to changes instead of absolute ratios. ${ }^{9}$ Effectively, I impose in this section that if the relative number of people with high skills increases by 10 percent in the population, the relative labour supply of high-skilled labour will also increase by 10 percent. This assumption is used to simulate the degree of relative wage compression, i.e. relative wage rigidity, that occurred since the beginning of the observation period, $t_{0}=1991$. To this end, the 'market relative wage', i.e. the relative wage that equates changes in relative demand to changes in relative supply, has to be calculated:

$$
\ln \left(\frac{w_{h t}}{w_{l t}}\right)=\left(\frac{1}{\sigma}\right)\left[\ln \left(\overline{\left.\frac{A_{h t}}{A_{l t}}\right)^{\sigma-1}}-\ln \left(\frac{S_{h t}}{S_{l t}}\right)\right]+\left\{\ln \left(\frac{w_{h t_{0}}}{w_{l t_{0}}}\right)-\left(\frac{1}{\sigma}\right)\left[\ln \widehat{\left(\frac{A_{h t_{0}}}{A_{l_{0}}}\right)^{\sigma-1}}-\ln \left(\frac{S_{h t_{0}}}{S_{l t_{0}}}\right)\right]\right\}\right.
$$

The first term of the sum on the right hand side of equation (2) is the relative wage which equates relative demand to relative supply. The second term \{in curly brackets $\}$ guarantees

\footnotetext{
${ }^{8}$ This is an adaptation of the framework by Katz and Murphy (1992), Autor, Katz and Krueger (1998), and Acemoglu, (2002a), in order to gauge the extent of relative wage rigidity.

${ }^{9}$ The microeconometric methodogy of the following section does not make this strong assumption.
} 
that in the base year, $t_{0}=1991$, the observed and the simulated relative wages are equal. For the following years, equation (2) states the wage that equates changes in relative demand to changes in relative supply, which is why I refer to it as the 'market relative wage'.

I take the difference between the observed relative wage and the simulated 'market relative wage' to be a quantitative indicator for relative wage rigidity in period $t, R W R_{t}$, where I set this rigidity indicator

$$
R W R_{t} \equiv \ln \left(\frac{w_{h t}}{w_{l t}}\right)-\ln \overline{\left(\frac{w_{h t}}{w_{l t}}\right)}
$$

equal to zero in the base period $t_{0}$ by definition. It can be shown by straightforward algebraic reformulation that

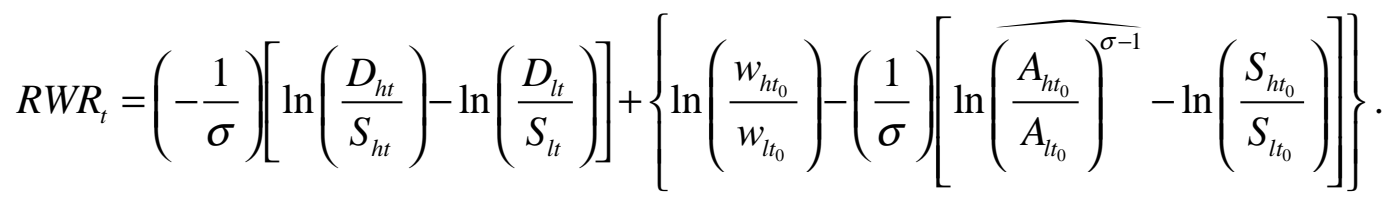

Hence, within this framework, the relative wage rigidity indicator is simply a function of the observed relative employment-population ratios of high- versus low-skilled labour plus the constant term in curly brackets (which sets $R W R$ equal to zero in the base period, $t_{0}=1991$ ).

In addition, this framework allows simulation of the relative supply effect on relative wages by holding the relative demand index fixed (e.g. equal to the level at some base period $t_{0}, 1991$ in my case):

$$
\ln \left(\overline{\frac{w_{h t}}{w_{l t}}}\right)=\left(\frac{1}{\sigma}\right)\left[\overline{\ln \left(\frac{A_{h t_{0}}}{A_{l t_{0}}}\right)^{\sigma-1}}-\ln \left(\frac{S_{h t}}{S_{l t}}\right)\right] .
$$

The series simulated in equation (5) will be called 'constant demand market relative wage' below. 
This simple macroeconomic framework is set up as a two skill model. Using data from the SLFS, I define high-skilled workers to be college or university degree holders, whereas low-skilled workers are defined to be persons with an apprenticeship certificate. The reason why I choose this group rather than workers with high school education (as in the US literature) to be the low skilled is that, in Switzerland, the apprenticeship certificate is the major low-skill degree (as is apparent from the sample means in Table A1). On the basis of the socio-economic characteristics described in the previous section, I define 100 ageeducation-gender-region cells. For each cell, I calculate the median (or the mean, the sensitivity of the results will be discussed later) wage and the size of the cell in terms of number of persons (using the SLFS sample weights). In order to calculate a wage series for university/college graduates, for example, I average the wage over all cells referring to university/college graduates using the average size of each cell in the sample period as a weight. Similarly, in order to obtain a supply series for e.g. university/college graduates, I average the size of all corresponding cells using the average wage of each cell as a weight (as in Katz and Murphy, 1992). The relative supply of high (university/college) over low (apprenticeship) skills is then calculated as the ratio of university/college over apprenticeship ‘equivalents' as in Autor, Katz, and Krueger (1998) and Acemoglu (2002a): I simulate higher vocational and advanced high school degree holders to entail 0.6 and 0.2 times the human capital of university/college degree holders and add them with these shares to this group in order to obtain a 'high-skill equivalent' series. To get a 'low-skill equivalent' series, I add 0.4 and 0.8 times the number of higher vocational and advanced high school degree holders to the apprenticeship certificate holders plus 0.5 times the number of workers with mandatory education or less. Relative wage and supply series are then obtained by taking the ratio of high- over low-skill wages or 'equivalent workers', respectively.

Table 1 displays the relative demand and supply indices for Switzerland between 1991 and 2001. The relative demand estimates are based on the assumption that the elasticity of 
substitution is 1.4. The first thing to observe is that both the relative demand and the relative supply of high-skilled over low-skilled labour increased considerably during the observation period. The 1991 to 2001 changes are 0.26 and $0.32 \log$ points for relative demand and supply, respectively (if one were to take cell mean instead of median wages as a measure, the corresponding figures are identical; results are available from the author upon request). There is some coincidence of unemployment changes with relative supply and demand changes. It turns out that relative demand increases were more in line with relative supply increases when unemployment was rising up to 1997 (the respective increases were 0.14 and 0.12 log points), but the relative supply of the high skilled increased somewhat faster when unemployment fell between 1997 and 2001: the increase in the relative supply and demand for skills during this period was 0.18 and $0.14 \log$ points, respectively (this holds no matter whether cell mean or median wages are used).

In order for these demand and supply developments over time to provide an explanation for the changes in the unemployment rate, there has to be some form of wage rigidity. Figure 3 simulates the 'market' relative wage by assuming that changes in relative population numbers equal changes in relative supplies and simulates the relative wage rigidity indicator $R W R_{t}$ as in equation (4) above ( $\sigma$ is assumed to be 1.4). A further simulation in Figure 3 holds the demand index constant at its 1991 level and shows what the 'market' relative wage would have been, had there only been supply, but no demand changes ( $c f$. equation (5)). As can be seen by comparing the observed and the 'market' relative wage, a small gap between these two lines emerges during the 1990s. This gap can be interpreted as an estimate of wage rigidity. The magnitude of the gap suggests that the ratio of high-skilled over low-skilled wages should have been around 1 percent higher in the late 1990s to have kept relative employment in line with relative supply changes ( $c f$. Table 1). This number albeit small and only statistically significant at the 10 percent level in 1995 - is robust across alternative specifications including self-employed workers and using cell mean instead of 
median wages. Using 1 and 2 instead of 1.4 as the elasticity of substitution renders a relative rigidity estimate of around 1.5 and 0.7 percent, respectively. Hence, the relative wage rigidity seems to be small according to these simulations. Therefore, relative wage rigidity (which corresponds to changes in the relative employment-population ratios as shown in equation (4)) does not seem to be the sole driving force behind the rise and fall of aggregate Swiss unemployment (see Section 2 for a short discussion of other factors). Nevertheless, the results presented here are still tentatively indicative of wage rigidities playing some role in the Swiss unemployment experience, an issue which will be investigated further in Section 5.

Table 1 and Figure 3 also demonstrate that increases in the relative supply of skilled labour contributed to a compression of the skill premium of $0.23 \log$ points between 1991 and 2001 (from the observed $0.51 \log$ points down to the simulated value of 0.28 ). As can be seen from the figure, the supply effect accelerated after 1997 when unemployment started to decrease again..$^{10}$ This increase in relative supply is very high if compared to Acemoglu's (2002a) results for the US between 1987 and 1997: Table 1, Panel B, in Acemoglu (2002a) suggests a relative skill supply increase of only $0.09 \log$ points $[=\log (0.743)-\log (0.609)]$. As the skill premium in Switzerland stayed constant or even fell during the observation period, my result is consistent with the claim by Gottschalk and Joyce (1998) that supply changes do matter more in explaining different developments in skill premia between countries than generally acknowledged in the literature.

As indicated above, Switzerland is due to its high living standard a very attractive country for immigrants. Because immigration policy is a hotly debated issue in Switzerland with popular votes on the limitation of immigration being held regularly (see Section 2 above), I simulate in Table 2 and Figure 4 the 'market' relative wage had there been no B (temporary) or no B nor C (permament) immigrants in the Swiss labour market, respectively.

\footnotetext{
${ }^{10}$ Table B4 in Appendix B shows that these supply changes are both related to an increase in higher education and a decrease in the share of workers with apprenticeship training or only mandatory schooling or less.
} 
Figure 4 clearly demonstrates that the exclusion of all (or just temporary) resident immigrants from the Swiss labour market would have increased the Swiss skill premium, because immigrants are on average higher qualified than Swiss workers. Moreover, there are no large changes in the gap between the 'market' wages with and without immigrants, except during the period 1991-1996, when this gap temporarily slightly increased. As unemployment reached its peak in 1997, this implies that the Swiss immigration regime successfully decreased the relative share of low-skilled immigrants during this period of relative demand shocks against this group. In Section 5, I present microeconometric evidence on this issue.

Table 2 also simulates the 'market' skill premium had only the low-skilled (apprenticeship or below) (temporary) immigrants left the country. If this policy had been imposed on all low-skilled temporary (B) work permit holders, the skill premium would have fallen by about $0.02 \log$ points, a rather small effect for an extreme policy. Only if all lowskilled immigrants (temporary and permanent) work permit holders had left the country, the skill premium would have fallen by around $0.12 \log$ points, a more sizeable amount. ${ }^{11}$ I thus conclude that the only viable immigration policy - decreasing further the number of temporary immigrants, would not have had very large effects even if taken to the extreme. Sheldon (2000) - using a very different conceptual approach - also concludes that the effects of immigrants on wages in Switzerland are rather small.

To sum up this section based on macroecomomic simulations, the fact that the skill premium in Switzerland during the 1990s stayed constant or even fell can primarily be attributed to a large increase in the relative supply of skilled workers, much larger than the one in the US during one decade. There is also some evidence for relative wage rigidity of the order of about 1 percent. This only weakly supports Krugman's (1994) hypothesis, as supply effects and not rigidities seem to be the most important driving force for the development of 
the skill premium over time. Furthermore, Swiss work permit policy somewhat accommodated the relative demand shock against the low skilled in the mid 1990s by temporarily changing the skill mix of the immigrant work force. However, even an extreme policy of sending all low-skilled temporary work permit holders to their home countries would not have changed the skill premium massively.

Because these macro simulations - despite their appeal - rest on strong assumptions and only distinguish between two skill groups, I will present some microeconometric evidence (with arguably less strong assumptions) on changes in the Swiss wage, unemployment, and non-employment structures in the following section.

\section{The Micro Picture: Changes in the Wage, Unemployment, Non- Employment, and Immigrant Share Structures}

\subsection{Empirical Aproach: Classification of Labour Market Characteristics}

The methodological approach used here to identify relative net demand shocks and wage rigidities concurs with Nickell and Bell (1996) and Gottschalk and Joyce (1997), where unemployment is used as a measure of quantity rationing in the presence of wage rigidities. However, unlike these authors, I consider several classes of skill in both the age (as a proxy for experience) and education dimensions and control for these as well as other labour supply factors (gender, region) in a regression framework in both the wage and unemployment models.

To describe ceteris paribus changes in the wage, unemployment and non-employment structures, I estimate standard log-linear wage and probit unemployment (or nonemployment) regressions on the samples described in Section 3 and used in the previous

\footnotetext{
${ }^{11}$ The implementation of such a policy would have meant the end of the rule of law in Switzerland, though, with permanent residence permit holders being deprived of their legal rights. This might have caused a massive credibility loss for Switzerland with severe economic as well as political effects.
} 
section. The theoretical justification for and identifying assumptions of the empirical approach introduced here is given in Appendix A. The models I estimate are:

$$
\begin{aligned}
& E\left[\ln W_{t} \mid \mathbf{x}\right]=\mathbf{x} \boldsymbol{\beta}_{t} \\
& E\left[U_{t} \mid \mathbf{x}\right]=\Phi\left(\mathbf{x} \boldsymbol{\gamma}_{t}\right)
\end{aligned}
$$

where $W$ is the hourly wage rate, $U$ an unemployment or non-employment indicator, $\mathbf{x}$ is a vector of dummy variables containing different categories of age, education, gender, and region. In comparison to the macro approach of the previous section, I thus explicitly consider two dimensions of skill (age and education). Furthermore, I distinguish between 5 different categories in both the age and education dimensions, rather than just allowing for 2 skill types as in the previous section. $\Phi(\cdot)$ is the cumulative distribution function of the standard normal distribution. Cross-sectional regressions are estimated separately for each year $t$ of the Swiss Labour Force Survey. Tests on the changes in the $\boldsymbol{\beta}$ and $\boldsymbol{\gamma}$ coefficients over time are then carried out to describe ceteris paribus changes in the wage and unemployment (or nonemployment) structures. By a change in the wage structure I mean, for example, a decrease in ceteris paribus youth wages in relation to some average wage. The 'average wage' or 'average unemployment (or non-employment) likelihood' is defined here as the estimated wage or unemployment likelihood for the 1991 sample mean of the labour force (or the population in the non-employment regressions). It can be shown that due to the non-linearities of these regression models, a transformation of the coefficients as in Haisken-New and Schmidt (1997) is required before differences across time in the coefficients can be interpreted as the contribution of the respective labour market characteristic to changes in wage or unemployment structures ( $c f$. Appendix A). The transformations are carried out such that dummy variable coefficients do not state the difference in the outcome variable with respect to a base category, but instead with respect to the 1991 sample mean. Therefore, my reported 
regression results below do not state a base category but show the transformed coefficients for all dummy variables.

Table 3 summarises the classification of labour market characteristics $x_{k}$ (e.g. young age, low level of education), based on the changes of its transformed coefficients (indicated by an asterisk), $\left(\beta_{1991+\tau, k}^{*}-\beta_{1991, k}^{*}\right)$ and $\left(\gamma_{1991+\tau, k}^{*}-\gamma_{1991, k}^{*}\right)$. Depending on the change of its regression coefficients over time, each labour market characteristic is contributing to a decreasing, constant, or increasing wage (or unemployment likelihood) relative to the reference market (here the 1991 sample mean). By observing wage and unemployment (or non-employment) changes jointly, each labour market characteristic can be classified into one of nine different cases. These are distinguished by increasing or decreasing relative demand (net of supply) and by whether the relative wage reacted to this relative net demand shock (see Appendix A for a further discussion of this methodology). The classifications (4) and (6) in Table 3 refer to flexible labour markets, where relative demand shocks cause relative price changes. Classifications (1), (2), and (3), however, refer to labour markets where potential relative demand shocks (not identified in case (1)) lead to quantity rationing in terms of higher relative unemployment. If Krugman's (1994) hypothesis applies to Switzerland, one should observe one of these classifications for a low-skilled group during the period from 1991 to 1997, when unemployment rose on average. Empirical results are presented in the following section.

\subsection{Relative Net Demand Shocks and Wage Rigidity}

The estimated coefficients of the age and education categories using SLFS data in the wage and unemployment regressions are displayed in in Figure 5 and Figure $6 .^{12}$ As outlined in

\footnotetext{
${ }^{12}$ The regression results are reported in Table B7 and Table B9 in Appendix B. Note that the coefficients are transformed as briefly explained in the previous subsection, so that the 'base' for the dummy variables is the 1991 sample mean of the unemployment regression sample (i.e. the average characteristics of the 1991 labour
} 
subsection 5.1 the purpose of this exercise is to identify relative net demand shocks and the existence of wage rigidities. Table A3 and Table A4 in Appendix A present the changes in the wage and unemployment coefficients over time, respectively. Each column reports the change in the coefficients between 1991 and the reported year as indicated above the respective column. Thus, the column headed 1997 exhibits the change in the coefficients between 1991 and 1997, whereas the 2001 column reports the coefficient changes between 1991 and 2001. The purpose of these tables is to show how the wage and unemployment structures changed between a low (1991) and a high (1997) unemployment year as well as between the two low unemployment years (1991 and 2001) which mark the beginning and the end of a special decade for the Swiss labour market. Note that due to the rotating panel nature of the Swiss Labour Force Survey, some persons are interviewed in several waves. Therefore, the number of persons is not equal to the number of observations up to the comparison year 1995. The standard errors used to obtain the $t$-values in parentheses are adjusted for this fact. In order to formally classify labour market characteristics as in Table 3, I apply a two-sided $t$-test at the 5 percent level to each category's coefficient in both the wage and unemployment regressions. ${ }^{13}$ On the basis of these tests, I classify each labour market characteristic into one of the nine categories of Table 3.

The result is reported in Table 4a. Each column of this table reports the classification for the indicated year with 1991 as the base year. As the table shows, there have been some changes in the Swiss wage and unemployment structures between 1991 and 2001. However, not many changes are persistent. Consider first the period 1991 to 1997 when average unemployment reached its peak. Perhaps surprisingly, there seem to have been no significant relative net demand shocks for any age group (together with the large fall in the share of

force). Accordingly, the transformed constant equals the estimated log wage for this reference market (hence the constant is called 1991 sample mean here).

${ }^{13}$ This is equivalent to a 10-percent-level Bonferroni test of the joint null hypothesis that there was neither a change in the wage nor the unemployment structure with respect to the tested category (e.g. mandatory school or less) (cf. Mittelhammer, Judge, and Miller, 2000, p.73 f.). 
young workers as demonstrated in Table A1 in Appendix A this suggests counteracting relative supply and demand shocks for this group). However, workers with an apprenticeship training have experienced a positive relative net demand shock (classification (8): weakly rigid in increasing market) whereas those with mandatory school or less have faced a negative relative net demand shock as the results for the years 1995 and 1996 indicate (classification (2): weakly rigid in a decreasing market) (see also Figure 6b). Given that the relative supply of workers with an apprenticeship training had not decreased (much) up to 1997 ( $c f$. Table A1), this result suggests that this group was not only unaffected by negative relative net demand shocks (where 'net' refers to demand net of supply), but also unaffected by pure negative relative demand shocks. ${ }^{14}$ This is an interesting result, as it means that the major low-skill group in Switzerland did not experience the same shocks as the major lowskill group in the United States (namely high school graduates, $c f$. Acemoglu, 2002a; b).

Concerning the increase in the unemployment likelihood for the least skilled group (with mandatory schooling or less), note that it occurred between 1994 and 1995. Hence, this result is unlikely to be distorted by frictional unemployment components as the major change in the unemployment benefit regime occurred already in early 1993 (cf. Section 2 and the theoretical discussion in the Appendix). Furthermore, the slight coding change of the education variable in the SLFS took place between 1995 and 1996 ( $c f$. Section 3). Therefore the timing of events suggests that the finding of an increased relative unemployment probability for the least skilled is not driven by measurement issues.

As the test results show, the wage structure did not respond to this negative net demand shock against the least skilled, pointing to an unemployment generating wage rigidity. Looking at the column for the year 2001 in Table $4 a$ - when the average unemployment rate had decreased again - reveals that this relative wage rigidity for the very

\footnotetext{
${ }^{14}$ Table B4 in Appendix B shows that the share of persons with apprenticeship training in the population did not decrease at all between 1991 and 1997.
} 
low skilled persisted until the end of the observation period (although it does not show up significantly between 1997 and 2000 in this specification). This finding is consistent with a recent study by the Swiss Federal Statistical Office (Bundesamt für Statistik, 2002) which shows that between 1999 and 2001 the average collectively bargained minimum wages (German: Gesamtarbeitsvertragliche Mindestlöhne) for unqualified workers (without apprenticeship) rose by 7 percent whereas those of qualified and highly qualified workers rose only by about 3 percent.

Before concluding that the Swiss wage structure is rigid with respect to the least skilled workers, I carry out some sensitivity checks. First, Switzerland is known for its flexible working time regime ( $c f$. Sousa-Poza and Henneberger, 2001). For example, instead of 50 percent (part-time) and 100 percent (full-time) working time contracts, 80 percent regimes are also not uncommon. Therefore, I also estimate the unemployment regressions with the degree of unemployment as the dependent variable. For example, if a person works 50 (80) percent but says he or she is currently looking for a full-time job, the dependent variable will indicate 50 (20) percent unemployment. Similarly, unemployed people looking only for part-time employment are also coded as 50 percent unemployed as opposed to those searching for full-time work, who are 100 percent unemployed. These degree of unemployment regressions are then estimated by OLS (with robust standard errors). Otherwise, the same testing procedure as in the previous analysis is applied (there are small changes in sample size due to some missings in the degree of unemployment questions). (Alternative estimation results based on a Tobit model with double censoring revealed almost the same classification results, which make no difference to the interpretation for the purposes of this paper).

Another sensitivity check I carry out is to run non-employment instead of unemployment regressions, as some non-employed people may be discouraged workers ( $c f$. 
Flinn and Heckman, 1983; Tano, 1991; or Gonul, 1992; and the references therein for the debate on whether 'unemployment' and 'out of the labour force' are behaviourally distinct states). Many North American labour economists therefore prefer non-employment rates to unemployment rates as a statistical measure for labour market flexibility. Note that by considering non-employment as a measure for unemployment, the sample size increases significantly as all 'non-participants' in the labour market are now included in the regressions. This also changes the 'reference' labour market somewhat (it is now the 1991 sample mean of the whole working age population, not just the labour force), which may also alter the transformed wage coefficients and affect the inference results when classifying labour market characteristics.

In order to check whether the relative wage rigidity for workers with mandatory school or less is robust to these alternative specifications, the reader is referred to the classification results exhibited in Table $4 \mathrm{~b}$ and Table $4 \mathrm{c}$ (based on the $t$-tests provided in Table A5 and Table A6). ${ }^{15}$ As can be seen from these tables, this finding is indeed robust across all three measures of 'unemployment'. So is the lack of a relative negative net demand shock against workers with apprenticeship training. In the degree of unemployment specifications, the rigidity for workers with mandatory school or less shows up in more years than in the binary unemployment model. This is probably because the degree of unemployment regressions use especially for women a more accurate measure of quantity rationing. Indeed, separate regressions for men and women (available from the author by request) show that women are more affected by the relative wage rigidity for the least skilled than men. In the non-employment specification, this rigidity appears first in 1999 and persists thereafter. However, the point estimates exhibited in Figure $6 c$ show that the increase in the non-employment likelihood is fairly steady from 1993 to 2001.

\footnotetext{
${ }^{15}$ Regression results for the degree of unemployment equations are presented in Table B10 of Appendix B. Sample means and estimation results for the non-employment regressions can be found in Table B4 and Table
} 
Another robust result across all specifications is the increase in the relative wage of the most experienced workers (aged 56-65), a phenomenon which has also been documented for the United States ( $c f$. Katz and Autor, 1999). In addition, the increasing demand for female relative to male workers is a robust finding. There seem to have been no clear net demand shocks in the regional dimension, although there is some indication of a temporary relative wage rigidity in the Latin part of Switzerland up to 1996 in the degree of unemployment specifications.

As a final robustness check, I use wage data from 1994 to 2000 from the Swiss Wage Structure Survey (WSS) as described in Section 3. The changes of the (transformed) coefficients with corresponding $t$-statistics are presented in Table $5 .{ }^{16}$ Testing for changes in the wage structures in Table 5 reveals that there has been a significant rise in the relative wage position of least skilled workers between 1994 and 2000 (a small rise for those with mandatory schooling or less, a larger rise for those with other education). ${ }^{17}$ Hence, the evidence from the WSS also substantiates the robust finding from the SLFS that the relative wage of the least skilled was not allowed to fall in Switzerland even in the face of rising relative unemployment and non-employment for this group. This is consistent with the Krugman (1994) hypothesis. An alternative explanation like efficiency wages is not plausible, as it is unclear why the least skilled should be more affected by them than high-skilled workers. Indeed, the least skilled should be the easiest to monitor, monitoring costs being a major ingredient to the efficiency wage hypothesis (Shapiro and Stiglitz, 1984). Furthermore, the timing of the relative wage increase in the WSS is consistent with the study by the Swiss

B11, respectively. Graphical illustrations of the development of the skill (age and education) coefficients over time are displayed in Figure 5 and Figure 6.

16 The cross-sectional regression coefficients are shown in Table B8 in Appendix B. Comparing the wage regressions from the SLFS in Table B7 with those from the WSS in Table B8 reveals almost identical coefficients with respect to the age, gender, and regional wage structures. However, there are some differences in the sizes of the education coefficients which may be related to the missing data problem or the sample population (private sector only) as discussed in Section 3.

${ }^{17}$ Although persons with other education have higher human capital than workers with mandatory schooling or less, they earn less than workers with apprenticeship training, as Table B8 in Appendix B demonstrates. 
Federal Statistical Office on union wage contracts between 1999 and 2001 (Bundesamt für Statistik, 2002, cf. Section 2).

Having established the negative relative net demand shock and relative wage rigidity for workers with mandatory education or less, I test in the following section whether the issuance of temporary work permits to immigrants responded to this shock.

\subsection{Changes in the Temporary Immigrant Structure}

Tests whether there have been changes in the temporary immigrant structure since the base year of 1991 are provided in Table 6 (the temporary (B) immigrant shares by subgroup are reported in Table A2 in the Appendix). Table 6 is based on probit regressions that estimate the probability of being a temporary work permit holder in the Swiss labour force depending on the same socio-economic characteristics as in the previous wage and unemployment regressions. ${ }^{18}$ The displayed changes in the coefficients can thus be interpreted as ceteris paribus changes in the temporary immigrant shares for the respective categories (relative to changes in the reference market, as in the wage and unemployment regressions above). Note that the dependent variable in these regressions equals 1 for temporary immigrants and 0 for Swiss persons and permanent immigrants. This specification reflects the fact that state treaties with many countries as well as legal issues restrict labour supply fine tuning essentially to temporary work permit holders ( $c f$. Section 2).

Table 6 shows that around 1997, when unemployment peaked in Switzerland, the relative temporary work permit share of persons with mandatory schooling or less was reduced. Although this result is only significant at the 10 percent level, it substantiates my macro simulation results of Section 4, which also suggests that work permit fine tuning worked effectively to change the skill mix of immigrant labour during the period of high

\footnotetext{
${ }^{18}$ The cross-sectional estimation results are shown in Table B12 of Appendix B. It demonstrates that workers with a very high or with a very low level of education are more likely to be temporary immigrants than those
} 
unemployment. However, it should be noted that the share of temporary immigrants on average increased together with unemployment. ${ }^{19}$

One may wonder whether this is a reflection of the fact that Swiss authorities were more reluctant to turn B (temporary) into $\mathrm{C}$ (permanent) permits when unemployment was high. However, when running the same model for the probability of being either a $\mathrm{B}$ or $\mathrm{C}$ immigrant, I find the same result: the share of immigrants increased on average. The point estimates still suggest a temporary change in the skill mix against the low-skilled, but this is not significant any more. My evidence is thus congruent with Flückiger's (1998) conclusion that the temporary work force was on average not responsive to shocks in the 1990s. However, my microeconometric results at least point to some fine tuning in the skill structure of temporary immigrants. Yet by the year 2001, this fine tuning had already been reversed, although the wage rigidity for the least skilled persisted as shown in Section 5.2 above.

\section{Conclusions}

This paper has investigated relative wage rigidities as well as the supply and demand for skills when unemployment rose and fell again in Switzerland during the 1990s. A macroeconomic simulation in the spirit of Katz and Murphy (1992) shows that the Swiss labour market - just like the one of the US - experienced a relative demand shock against the low skilled in the 1990s. The fact that the relative supply of skilled workers increased by a larger amount than in the US in a similar period partly explains why the Swiss skill premium has stayed fairly constant. However, simulation results also tentatively suggest that wage rigidities may account for another part of the relatively stable skill premium.

The microeconometric part of the paper substantiates the stylised picture drawn by the macro simulations. On the supply side, the Swiss labour force has experienced a decrease in 
the share of low-skilled workers with only apprenticeship training since around 1997. What is remarkable, though, is that the rise in Swiss unemployment in the first half the 1990s was not accompanied by a relative demand shock against workers with apprenticeship training. This indicates that the Swiss-/German-style apprenticeship system has shielded the largest part of low-skilled workers in Switzerland from the negative demand shocks affecting high school graduates in the US. By jointly observing changes in the wage and unemployment structures, only the skill group of workers with mandatory school or less could be identified to have experienced a negative relative net demand shock during the 1990s. However, the relative wage for this group did not respond to this relative demand shock, thus indicating a relative wage rigidity. Although the average level of unemployment had come down by the year 2001, this relative wage rigidity persisted until the end of the observation period. Whether one measures unemployment by non-employment or allows for part-time unemployment, this result is robust in all specifications. It is also robust in an alternative data set, the Swiss Wage Structure Survey. In sum, the finding of a relative wage rigidity for the least skilled is consistent with the Krugman (1994) hypothesis, but the Swiss experience also points to the importance of supply-side effects in explaining the relatively stable skill premium when compared to the US.

Being one of Europe's most prosperous countries with almost 20 percent of the population foreign, immigration policy is always a contentious issue in Switzerland, as regular popular votes on whether to restrict immigration policy demonstrate. Both the macro simulations and the microeconometric analysis show that some fine-tuning in the skill mix of immigrants with a temporary work permit took place when unemployment in Switzerland reached its peak. However, the macro simulations have demonstrated that even if all lowskilled temporary work permit holders had left the country, the effect on relative 'market' wages of high- versus low-skilled workers would have been rather small.

${ }^{19} C f$. Table B9 and Table B12 in Appendix B. 


\section{References}

Acemoglu, D. (2002a): Cross-Country Inequality Trends, NBER Working Paper No. 8832, Cambridge, MA, forthcoming in: Economic Journal.

Acemoglu, D. (2002b): Technical Change, Inequality, and the Labor Market, forthcoming in: Journal of Economic Literature.

Autor, D.H., L.F. Katz, and A.B. Krueger (1998): Computing Inequality: Have Computers Changed the Labor Market?, Quarterly Journal of Economics 113: 1169-1213.

Blau, F.D. and L.M. Kahn (1996): International Differences in Male Wage Inequality: Institutions versus Market Forces, Journal of Political Economy 104: 791-837.

Bundesamt für Ausländerfragen (2000): Die Ausländer in der Schweiz, Statistischer Bericht $2 A$ [The Immigrants of Switzerland, Statistical Report 2A], Bern-Wabern, December 2000 .

Bundesamt für Statistik (2002): Mindestlöhne in der Schweiz, Analyse der Mindestlohn- und Arbeitszeitregelungen in den Gesamtarbeitsverträgen von 1999 - 2001 [Minimum Wages in Switzerland, An Analysis of Minimum Wage and Working Time Regulations in General Collective Bargaining Contracts 1999-2000], Neuchâtel 2002, ordering number 497-0100.

Card, D., F. Kramarz, and T. Lemieux (1999): Changes in the Relative Structure of Wages and Employment: A Comparison of the United States, Canada, and France, Canadian Journal of Economics 32: 843-877.

Fehr, E. and L. Goette (2000): Robustness and Real Consequences of Nominal Wage Rigidity, Institute for Empirical Research in Economics, University of Zürich, Working Paper No. 44.

Flinn, C. and J.J. Heckman (1983): Are Unemployment and Out of the Labor Force Behaviorally Distinct Labor Force States?, Journal of Labor Economics 1: 28-42.

Flückiger, Y. (1998): The Labour Market in Switzerland: The End of a Special Case?, International Journal of Manpower 19: 369-395.

Freeman, R. and R. Schettkat (2000): Skill Compression, Wage Differentials and Employment: Germany vs. the US, NBER Working Paper No. 7610, Cambridge, MA.

Gerfin, M. and M. Lechner (2002): A Microeconomic Evaluation of the Active Labour Market Policy in Switzerland, Economic Journal 112: 854-893. 
Gonul, F. (1992): New Evidence on Whether Unemployment and Out of the Labor Force are Distinct States, Journal of Human Resources 27: 329-361.

Gottschalk, P. and M. Joyce (1998): Cross-National Differences in the Rise of Earnings Inequality: Market and Institutional Factors, Review of Economics and Statistics 80: 489-502.

Haisken-DeNew, J.P. and C.M. Schmidt (1997): Interindustry and Interregion Differentials: Mechanics and Interpretation, Review of Economics and Statistics 79: 516-521.

Kahn, L.M. (2000): Wage Inequality, Collective Bargaining, and Relative Employment from 1985 to 1994: Evidence from Fifteen OECD Countries, Review of Economics and Statistics 82: 564-579.

Katz, L. and K. Murphy (1992): Changes in Relative Wages 1963-1987: Supply and Demand Factors, Quarterly Journal of Economics 107: 35-78.

Katz, L.F. and D.H. Autor (1999): Changes in Wage Structure and Earnings Inequality in: O.C. Ashenfelter and D. Card (eds.): Handbook of Labor Economics. Handbooks in Economics, Vol. 3A., Amsterdam: Elsevier, 1463-1555.

Krueger, A.B. and J-S. Pischke (1997): Observations and Conjectures on the U.S. Employment Miracle, NBER Working Paper No. 6146, Cambridge MA.

Krugman, P. (1994): Past and Prospective Causes of High Unemployment, Economic Review, Federal Reserve Bank of Kansas City, 23-43.

Lalive, R., J.C. van Ours, and J. Zweimüller (2002a): The Impact of Active Labor Market Programs on the Duration of Unemployment, Institute for Empirical Research in Economics Working Paper No. 41, University of Zürich.

Lalive, R., J.C. van Ours, and J. Zweimüller (2002b): The Effect of Benefit Sanctions on the Duration of Unemployment, IZA Discussion Paper No. 469, Bonn.

Liebig, T. (2002): Switzerland's Immigration Policy: Lessons for Germany?, Discussion Paper No. 76, Forschungsinstitut für Arbeit und Arbeitsrecht an der Universität St. Gallen, http://www.faa.unisg.ch/Publikationen/publikationen_site.htm.

Mittelhammer, R.C., G.G. Judge, and D.J. Miller (2000): Econometric Foundations, Cambridge: Cambridge University Press.

Nickell, S. and B. Bell (1996): Changes in the Distribution of Wages and Unemployment in OECD Countries, American Economic Review Papers and Proceedings 86: 302-321.

OECD (1993): Employment Outlook, Paris: OECD.

OECD (1996a): Employment Outlook, Paris: OECD. 
OECD (1996b): Labour Market Policies in Switzerland, Paris: OECD.

OECD (1997): Employment Outlook, July 1997, Paris: OECD.

Puhani, P.A. (2001): Wage Rigidities in Western Germany? Microeconometric Evidence from the 1990s, CEPR Discussion Paper No. 3009, London.

Schmid, H. (1998): Arbeitslosigkeit in der Schweiz des 20. Jahrhunderts [Unemployment in $20^{\text {th }}$ Century Switzerland], in: T. Geiser, H. Schmid, and E. Walter-Busch (eds.): Arbeit in der Schweiz des 20. Jahrhunderts [Labour in $20^{\text {th }}$ Century Switzerland], Bern: Verlag Paul Haupt.

SECO (State Secretariat for Economic Affairs) (2002): Chronologie der Ereignisse bzgl. AVIG Revisionen [Chronology of Events Concerning Revisions of the Mandatory Unemployment Insurance and Insolvency Compensation], SECO, mimeo, Bern: SECO.

Shapiro, C. and J.E. Stiglitz (1984): Equilibrium Unemployment as a Worker Discipline Device, American Economic Review 74: 433-444.

Sheldon, G. (2000): The Impact of Foreign Labor on Relative Wages and Growth in Switzerland, Working Paper, University of Basle.

Sousa-Poza, A. and F. Henneberger (2001): Working-Time Policies in Switzerland: An Analysis of Desired Working Time, Overtime, and Hours Constraints of Swiss Salaried Employees, Discussion Paper No. 69, Forschungsinstitut für Arbeit und $\begin{array}{llll}\text { Arbeitsrecht an } \quad \text { Universität St. Gallen, } & \text { Ser }\end{array}$ http://www.faa.unisg.ch/Publikationen/publikationen_site.htm.

Stutzer, A. and R. Lalive (2001): The Role of Social Work Norms in Job Searching and Subjective Well-Being, Institute for Empirical Research in Economics Working Paper No. 51, University of Zürich.

Swiss Federation of Trade Unions (1998): Expertenbericht Mindestlöhne [Experts' Report on Minimum Wages], downloadable from: http://www.sgb.ch/ddownload/mindestlohn.pdf.

Tano, D.K. (1991): Are Unemployment and Out of the Labor Force Behaviorally Distinct Labor Force States? New Evidence from the Gross Change Data, Economics Letters 36: 113-117.

Weber, B.A. (2001): Arbeitslosigkeit in der Schweiz: Was passierte in den Neunzigerjahren? [Unemployment in Switzerland: What Happened in the Nineties?], Die Volkswirtschaft 6-2001: 4-9. 
Table 1: Macro Simulations: Demand Supply, and Wage Rigidity

\begin{tabular}{ccccccc}
\hline \hline Year & $\begin{array}{c}\text { Observed } \\
\text { Relative } \\
\text { Wage }\end{array}$ & $\begin{array}{c}\text { Relative } \\
\text { Demand }\end{array}$ & $\begin{array}{c}\text { Relative } \\
\text { Supply }\end{array}$ & $\begin{array}{c}\text { 'Market' } \\
\text { Relative } \\
\text { Wage }\end{array}$ & $\begin{array}{c}\text { 'Constant } \\
\text { Demand } \\
\text { Market } \\
\text { Relative } \\
\text { Wage' }\end{array}$ & $\begin{array}{c}\text { Relative } \\
\text { Wage } \\
\text { Rigidity } \\
\text { (RWR })\end{array}$ \\
\hline 1991 & 0.51 & -0.78 & -1.58 & 0.51 & 0.51 & 0.00 \\
1992 & 0.46 & -0.79 & -1.53 & 0.46 & 0.47 & 0.00 \\
1993 & 0.46 & -0.75 & -1.50 & 0.47 & 0.45 & -0.01 \\
1994 & 0.48 & -0.71 & -1.48 & 0.48 & 0.44 & 0.00 \\
1995 & 0.46 & -0.73 & -1.48 & 0.47 & 0.44 & $-0.01 *$ \\
1996 & 0.46 & -0.69 & -1.44 & 0.47 & 0.41 & -0.01 \\
1997 & 0.49 & -0.66 & -1.45 & 0.50 & 0.41 & -0.01 \\
1998 & 0.45 & -0.66 & -1.40 & 0.46 & 0.38 & -0.01 \\
1999 & 0.47 & -0.59 & -1.36 & 0.49 & 0.35 & -0.01 \\
2000 & 0.45 & -0.59 & -1.32 & 0.46 & 0.32 & -0.01 \\
2001 & 0.46 & -0.52 & -1.27 & 0.47 & 0.28 & -0.01 \\
\hline \hline
\end{tabular}

Note: All numbers are given in logarithms of the ratio of the high-skilled over the low-skilled figure, as described in the text. For example, the relative wage is the logarithm of the ratio of the high-skilled over the low-skilled wage. These simulations assume $\sigma=1.4$. Bootstrap 90 percent confidence intervals for the estimated relative wage rigidity suggest that only the figure for 1995 is significantly different from zero. The confidence intervals are based on 500 bootstrap replications.

Source: Swiss Labor Force Survey; own calculations.

Table 2: Macro Simulations with Alternative Immigrant Regimes

\begin{tabular}{|c|c|c|c|c|c|c|c|c|c|}
\hline \multirow[t]{2}{*}{ Year } & \multirow[t]{2}{*}{$\begin{array}{l}\text { 'Market' } \\
\text { Relative } \\
\text { Wage }\end{array}$} & \multicolumn{2}{|c|}{$\begin{array}{l}\text { 'Market Relative } \\
\text { Wage' No B } \\
\text { Immigrants }\end{array}$} & \multicolumn{2}{|c|}{$\begin{array}{l}\text { 'Market Relative } \\
\text { Wage' No B \& C } \\
\text { Immigrants }\end{array}$} & \multicolumn{2}{|c|}{$\begin{array}{c}\text { 'Market Relative } \\
\text { Wage' No Low- } \\
\text { Skilled B Immigrants }\end{array}$} & \multicolumn{2}{|c|}{$\begin{array}{l}\text { 'Market Relative } \\
\text { Wage' No Low- } \\
\text { Skilled B \& C } \\
\text { Immigrants }\end{array}$} \\
\hline & & $\begin{array}{l}\text { Simu- } \\
\text { lation }\end{array}$ & $\begin{array}{l}\text { Difference } \\
\text { to Market }\end{array}$ & $\begin{array}{l}\text { Simu- } \\
\text { lation }\end{array}$ & $\begin{array}{l}\text { Difference } \\
\text { to Market }\end{array}$ & $\begin{array}{l}\text { Simu- } \\
\text { lation }\end{array}$ & $\begin{array}{l}\text { Difference } \\
\text { to Market }\end{array}$ & $\begin{array}{l}\text { Simu- } \\
\text { lation }\end{array}$ & $\begin{array}{l}\text { Difference } \\
\text { to Market }\end{array}$ \\
\hline 1991 & 0.51 & 0.54 & 0.03 & 0.54 & 0.03 & 0.50 & -0.01 & 0.40 & -0.11 \\
\hline 1992 & 0.46 & 0.50 & 0.04 & 0.50 & 0.04 & 0.45 & -0.01 & 0.35 & -0.11 \\
\hline 1993 & 0.47 & 0.49 & 0.03 & 0.49 & 0.02 & 0.45 & -0.02 & 0.35 & -0.11 \\
\hline 1994 & 0.48 & 0.51 & 0.02 & 0.51 & 0.02 & 0.47 & -0.02 & 0.37 & -0.12 \\
\hline 1995 & 0.47 & 0.51 & 0.04 & 0.51 & 0.04 & 0.45 & -0.02 & 0.36 & -0.12 \\
\hline 1996 & 0.47 & 0.53 & 0.06 & 0.52 & 0.05 & 0.45 & -0.03 & 0.35 & -0.12 \\
\hline 1997 & 0.50 & 0.54 & 0.05 & 0.54 & 0.04 & 0.48 & -0.02 & 0.38 & -0.12 \\
\hline 1998 & 0.46 & 0.51 & 0.05 & 0.50 & 0.04 & 0.44 & -0.02 & 0.34 & -0.12 \\
\hline 1999 & 0.49 & 0.54 & 0.05 & 0.52 & 0.04 & 0.47 & -0.02 & 0.37 & -0.12 \\
\hline 2000 & 0.46 & 0.50 & 0.04 & 0.49 & 0.04 & 0.43 & -0.02 & 0.33 & -0.12 \\
\hline 2001 & 0.47 & 0.50 & 0.03 & 0.50 & 0.03 & 0.45 & -0.02 & 0.35 & -0.12 \\
\hline
\end{tabular}

Note: All numbers are given in logarithms of the ratio of the high-skilled over the low-skilled figure, as described in the text. For example, the relative wage is the logarithm of the ratio of the high-skilled over the low-skilled wage. The 'Difference to Market' columns state the difference between the respective simulation and the 'Market Relative Wage' displayed in the second column of the table. These simulations assume $\sigma=1.4$.

Source: Swiss Labor Force Survey; own calculations. 
Table 3: Relative Wage and Unemployment Behaviour and Labour Market Classification

\begin{tabular}{|c|c|c|c|}
\hline & $\begin{array}{c}\text { Contributing to a } \\
\text { relative } \\
\text { unemployment } \\
\text { decrease } \\
\left(\gamma_{t+\tau, k}^{*}-\gamma_{t, k}^{*}\right)<0\end{array}$ & $\begin{array}{c}\text { Contributing to a } \\
\text { constant relative } \\
\text { unemployment } \\
\left(\gamma_{t+\tau, k}^{*}-\gamma_{t, k}^{*}\right)=0\end{array}$ & $\begin{array}{c}\text { Contributing to a } \\
\text { relative } \\
\text { unemployment } \\
\text { increase } \\
\left(\gamma_{t+\tau, k}^{*}-\gamma_{t, k}^{*}\right)>0\end{array}$ \\
\hline $\begin{array}{c}\begin{array}{c}\text { Contributing to a } \\
\text { relative wage } \\
\text { increase }\end{array} \\
\left(\beta_{t+\tau, k}^{*}-\beta_{t, k}^{*}\right)>0\end{array}$ & $\begin{array}{l}\text { (7): } \\
\text { weakly adjusting in } \\
\text { increasing market } \\
\text { relative to the } \\
\text { reference market }\end{array}$ & $\begin{array}{c}(6) \text { : } \\
\text { strongly adjusting in } \\
\text { increasing market } \\
\text { relative to the } \\
\text { reference market }\end{array}$ & $\begin{array}{c}\text { (1): } \\
\text { strongly rigid } \\
\text { (wage push) } \\
\text { relative to the } \\
\text { reference market }\end{array}$ \\
\hline $\begin{array}{c}\begin{array}{c}\text { Contributing to a } \\
\text { constant relative }\end{array} \\
\text { wage } \\
\left(\beta_{t+\tau, k}^{*}-\beta_{t, k}^{*}\right)=0\end{array}$ & $\begin{array}{l}(8): \\
\text { weakly rigid in } \\
\text { increasing market } \\
\text { relative to the } \\
\text { reference market }\end{array}$ & $\begin{array}{c}(5): \\
\text { stable in stable } \\
\text { market relative to } \\
\text { the reference market }\end{array}$ & $\begin{array}{c}(2): \\
\text { weakly rigid in } \\
\text { decreasing market } \\
\text { relative to the } \\
\text { reference market }\end{array}$ \\
\hline $\begin{array}{l}\begin{array}{c}\text { Contributing to a } \\
\text { relative wage } \\
\text { decrease }\end{array} \\
\left(\beta_{t+\tau, k}^{*}-\beta_{t, k}^{*}\right)<0\end{array}$ & $\begin{array}{c}\text { (9): } \\
\text { converging } \\
\text { (wage pull) relative } \\
\text { to the reference } \\
\text { market }\end{array}$ & $\begin{array}{c}\text { (4): } \\
\text { strongly adjusting in } \\
\text { decreasing market } \\
\text { relative to the } \\
\text { reference market }\end{array}$ & $\begin{array}{l}\text { (3): } \\
\text { weakly adjusting in } \\
\text { decreasing market } \\
\text { relative to the } \\
\text { reference market }\end{array}$ \\
\hline
\end{tabular}

Note: The terminology 'increasing market' refers to a positive net demand shock (which is the same as a negative net supply shock, as defined in the model in the Appendix). Increasing markets relative to the reference market are identified in cases (6), (7), and (8). Analogously, a 'decreasing market' is equivalent to a negative net demand shock. Decreasing markets relative to the reference market are identified in cases (2), (3), and (4). In cases (1) and (9), the sign of the net demand shock cannot be identified. In case (5), there is no such shock. 
Table 4a: Classification Summary with Unemployment Regressions

\begin{tabular}{|c|c|c|c|c|c|c|c|c|c|c|}
\hline Variable & 1992 & 1993 & 1994 & 1995 & 1996 & 1997 & 1998 & 1999 & 2000 & 2001 \\
\hline 1991 sample mean & 1 & 1 & 1 & 1 & 2 & 2 & 2 & 2 & 2 & 2 \\
\hline \multicolumn{11}{|l|}{ Age } \\
\hline $16-25$ & $\circ$ & ○ & ○ & ० & ○ & O & O & 6 & ○ & ० \\
\hline $26-35$ & O & 4 & 4 & 4 & ○ & ○ & ○ & 4 & 4 & ○ \\
\hline $36-45$ & ○ & ○ & ○ & ○ & ○ & ○ & ○ & 4 & ○ & ○ \\
\hline $46-55$ & O & ○ & ○ & ○ & ○ & ○ & O & ○ & ○ & ○ \\
\hline $56-65$ & O & O & 6 & 6 & O & O & 6 & 6 & 6 & 6 \\
\hline
\end{tabular}

Education

Higher

Higher vocational

Advanced high school

Apprenticeship

Mandatory school or less

Gender

Female

Male

Region of Residence

German part

Latin part

$\begin{array}{lllll}0 & 8 & 0 & 0 & 0 \\ 0 & 0 & 0 & 0 & 0 \\ 2 & 0 & 0 & 0 & 0 \\ 0 & 0 & 0 & 0 & 0 \\ 0 & 0 & 0 & 2 & 2\end{array}$

Note: The classifications in this table are based on the tests reported in Table A3 and Table A4 in Appendix A. See also notes and sources to Table 4c.

Table 4b: Classification Summary with Degree of Unemployment Regressions

\begin{tabular}{|c|c|c|c|c|c|c|c|c|c|c|}
\hline Variable & 1992 & 1993 & 1994 & 1995 & 1996 & 1997 & 1998 & 1999 & 2000 & 2001 \\
\hline 1991 sample mean & 1 & 1 & 1 & 1 & 2 & 2 & 2 & 2 & 2 & 2 \\
\hline \multicolumn{11}{|l|}{ Age } \\
\hline $16-25$ & ○ & ○ & O & ○ & O & ○ & O & 0 & O & $\circ$ \\
\hline $26-35$ & o & 4 & 4 & 4 & ○ & ० & o & 4 & 4 & ○ \\
\hline $36-45$ & ○ & o & 8 & ○ & ○ & ○ & ○ & 4 & ○ & ○ \\
\hline $46-55$ & ○ & ○ & ○ & ○ & ○ & ○ & O & O & ○ & $\circ$ \\
\hline $56-65$ & ○ & ○ & 6 & 6 & O & ○ & 6 & 6 & 6 & 6 \\
\hline \multicolumn{11}{|l|}{ Education } \\
\hline Higher & o & 8 & o & o & o & o & o & o & o & ○ \\
\hline Higher vocational & O & o & o & 8 & 8 & o & o & 8 & 8 & ○ \\
\hline Advanced high school & 2 & o & o & o & O & o & o & o & o & ○ \\
\hline Apprenticeship & o & o & o & o & O & 8 & o & o & o & 8 \\
\hline Mandatory school or less & ○ & ○ & o & 2 & 2 & 2 & o & 2 & 2 & 2 \\
\hline \multicolumn{11}{|l|}{ Gender } \\
\hline Female & ○ & 6 & ○ & 6 & 6 & 7 & $\circ$ & 6 & 6 & 6 \\
\hline Male & ○ & 4 & $\circ$ & 4 & 4 & 3 & ○ & 4 & 4 & 4 \\
\hline \multicolumn{11}{|l|}{ Region of Residence } \\
\hline German part & 8 & O & 8 & 8 & 8 & O & o & ○ & o & $\circ$ \\
\hline Latin part & 2 & O & 2 & 2 & 2 & O & O & ○ & ○ & ○ \\
\hline
\end{tabular}

Note: The classifications in this table are based on the tests (almost identical - available on request - to the ones reported) in Table A3 and the tests in Table A5 in Appendix A. See also notes and sources to Table 4c. 
Table 4c: Classification Summary with Non-Employment Regressions

\begin{tabular}{|c|c|c|c|c|c|c|c|c|c|c|}
\hline Variable & 1992 & 1993 & 1994 & 1995 & 1996 & 1997 & 1998 & 1999 & 2000 & 2001 \\
\hline 1991 sample mean & 6 & 1 & 1 & 1 & 2 & 2 & 2 & 2 & 2 & 6 \\
\hline \multicolumn{11}{|l|}{ Age } \\
\hline $16-25$ & o & O & 0 & 0 & 0 & 0 & ○ & ○ & O & 0 \\
\hline $26-35$ & ○ & 3 & 4 & 4 & 4 & ० & ○ & 9 & 4 & ○ \\
\hline $36-45$ & o & O & 0 & 0 & 0 & 0 & $\circ$ & 4 & O & 4 \\
\hline $46-55$ & ○ & ○ & O & ○ & O & 0 & ○ & ○ & ○ & ○ \\
\hline $56-65$ & ० & ○ & 7 & 6 & ० & ○ & 6 & 6 & ○ & 6 \\
\hline \multicolumn{11}{|l|}{ Education } \\
\hline Higher & O & ○ & O & O & O & O & O & O & O & O \\
\hline Higher vocational & ○ & O & ○ & ० & 8 & ० & ० & 8 & ○ & ० \\
\hline Advanced high school & ○ & ○ & 8 & ० & ० & ० & ○ & ० & ○ & ० \\
\hline Apprenticeship & O & ○ & O & O & O & O & ○ & O & O & O \\
\hline Mandatory school or less & ○ & ○ & ○ & ○ & o & ○ & ○ & 2 & 2 & 2 \\
\hline \multicolumn{11}{|l|}{ Gender } \\
\hline Female & ० & 7 & 8 & 7 & 7 & 7 & 8 & 7 & 7 & 7 \\
\hline Male & ० & 3 & 2 & 3 & 3 & 3 & 2 & 3 & 3 & 3 \\
\hline \multicolumn{11}{|l|}{ Region of Residence } \\
\hline German part & ○ & O & O & O & O & O & O & O & ○ & O \\
\hline Latin part & O & O & O & O & O & O & O & O & O & O \\
\hline
\end{tabular}

Note: The classifications in this table are based on the tests (almost identical - available on request - to the ones reported) in Table A3 and the tests in Table A6 in Appendix A. The classification codes are as follows: (1): strongly rigid (rising relative wage and rising relative unemployment); (2): weakly rigid in a decreasing market (constant relative wage and rising relative unemployment); (3): weakly adjusting in a decreasing market (falling relative wage and rising relative unemployment); (4): strongly adjusting in a decreasing market (falling relative wage and constant relative unemployment); $(O=5)$ : stable in a stable market (constant relative wage and constant relative unemployment); (6): strongly adjusting in an increasing market (rising relative wage and constant relative unemployment); (7): weakly adjusting in an increasing market (rising relative wage and falling relative unemployment); (8): weakly rigid in an increasing market (constant relative wage and falling relative unemployment); (9): converging (falling relative wage and falling relative unemployment);

note that for the 1991 sample mean, the classification refers to absolute, not relative wage and unemployment changes, for the other characteristics, the relative wage and unemployment changes refer to the 1991 sample mean.

Source: Swiss Labor Force Survey; own calculations. 
Table 5: WSS Wage Regressions (Changes in Transformed Coefficients with Respect to 1994 - Corresponding t-values in Parentheses)

\begin{tabular}{|c|c|c|c|}
\hline Variable & 1996 & 1998 & 2000 \\
\hline \multirow[t]{2}{*}{1991 sample mean } & -0.013 & -0.004 & 0.001 \\
\hline & $-(9.0)$ & $-(2.5)$ & $(1.0)$ \\
\hline \multicolumn{4}{|l|}{ Age } \\
\hline \multirow[t]{2}{*}{$16-25$} & -0.004 & -0.010 & 0.004 \\
\hline & $-(1.4)$ & $-(3.3)$ & $(1.3)$ \\
\hline \multirow[t]{2}{*}{$26-35$} & 0.006 & 0.005 & 0.008 \\
\hline & $(2.9)$ & $(2.2)$ & $(4.1)$ \\
\hline \multirow[t]{2}{*}{$36-45$} & -0.008 & -0.006 & -0.011 \\
\hline & $-(3.0)$ & $-(2.3)$ & $-(4.5)$ \\
\hline \multirow[t]{2}{*}{$46-55$} & 0.001 & 0.001 & -0.004 \\
\hline & $(0.4)$ & $(0.3)$ & $-(1.4)$ \\
\hline \multirow[t]{2}{*}{$56-65$} & 0.005 & 0.014 & 0.005 \\
\hline & $(1.0)$ & $(2.8)$ & $(1.0)$ \\
\hline \multicolumn{4}{|l|}{ Education } \\
\hline \multirow[t]{2}{*}{ Higher } & -0.035 & 0.002 & 0.015 \\
\hline & $-(3.6)$ & $(0.3)$ & $(1.6)$ \\
\hline \multirow[t]{2}{*}{ Higher vocational } & -0.031 & 0.009 & 0.025 \\
\hline & $-(6.2)$ & $(1.9)$ & $(5.3)$ \\
\hline \multirow[t]{2}{*}{ Advanced high school } & 0.045 & 0.032 & 0.069 \\
\hline & $(3.5)$ & $(2.4)$ & $(5.1)$ \\
\hline \multirow[t]{2}{*}{ Apprenticeship } & 0.000 & -0.003 & -0.013 \\
\hline & $(0.1)$ & $-(2.0)$ & $-(9.3)$ \\
\hline \multirow{2}{*}{ Mandatory or less } & 0.015 & 0.000 & 0.005 \\
\hline & $(6.7)$ & $(0.2)$ & $(2.3)$ \\
\hline \multirow[t]{2}{*}{ Other } & -0.025 & -0.016 & 0.035 \\
\hline & $-(2.2)$ & $-(1.5)$ & $(3.4)$ \\
\hline \multicolumn{4}{|l|}{ Gender } \\
\hline \multirow[t]{2}{*}{ Female } & 0.001 & 0.005 & 0.008 \\
\hline & $(0.7)$ & $(3.0)$ & $(4.5)$ \\
\hline \multirow[t]{2}{*}{ Male } & -0.001 & -0.003 & -0.005 \\
\hline & $-(0.7)$ & $-(3.0)$ & $-(4.5)$ \\
\hline \multicolumn{4}{|l|}{ Region of Residence } \\
\hline \multirow[t]{2}{*}{ German part } & -0.001 & 0.001 & 0.002 \\
\hline & $-(0.9)$ & $(1.2)$ & $(2.4)$ \\
\hline \multirow[t]{2}{*}{ Latin part } & 0.002 & -0.003 & -0.006 \\
\hline & $(0.9)$ & $-(1.2)$ & $-(2.4)$ \\
\hline \# observations & 754,293 & 734,092 & 813,794 \\
\hline
\end{tabular}

Source: Swiss Wage Structure Survey (WSS) (BFS, Lohnstrukturerhebung); own calculations. 
Table 6: Temporary Immigrant Regressions (Changes in Transformed Coefficients with Respect to 1991 - Corresponding t-values in Parentheses)

\begin{tabular}{|c|c|c|c|c|c|c|c|c|c|c|}
\hline Variable & 1992 & 1993 & 1994 & 1995 & 1996 & 1997 & 1998 & 1999 & 2000 & 2001 \\
\hline 1991 sample mean & $\begin{array}{l}0.04 \\
(0.8)\end{array}$ & $\begin{array}{l}0.05 \\
(0.8)\end{array}$ & $\begin{array}{l}0.06 \\
(0.9)\end{array}$ & $\begin{array}{l}0.14 \\
(2.3)\end{array}$ & $\begin{array}{l}0.33 \\
(4.7)\end{array}$ & $\begin{array}{l}0.17 \\
(2.4)\end{array}$ & $\begin{array}{l}0.27 \\
(4.0)\end{array}$ & $\begin{array}{l}0.21 \\
(3.3)\end{array}$ & $\begin{array}{l}0.15 \\
(2.0)\end{array}$ & $\begin{array}{l}0.22 \\
(3.2)\end{array}$ \\
\hline \multicolumn{11}{|l|}{ Age } \\
\hline $16-25$ & $\begin{array}{l}-0.10 \\
-(1.2)\end{array}$ & $\begin{array}{l}-0.14 \\
-(1.2)\end{array}$ & $\begin{array}{l}0.06 \\
(0.5)\end{array}$ & $\begin{array}{l}-0.01 \\
-(0.1)\end{array}$ & $\begin{array}{l}-0.02 \\
-(0.1)\end{array}$ & $\begin{array}{l}0.03 \\
(0.2)\end{array}$ & $\begin{array}{l}0.07 \\
(0.5)\end{array}$ & $\begin{array}{l}0.01 \\
(0.1)\end{array}$ & $\begin{array}{l}-0.21 \\
-(1.4)\end{array}$ & $\begin{array}{l}-0.07 \\
-(0.5)\end{array}$ \\
\hline $26-35$ & $\begin{array}{l}0.00 \\
(0.0)\end{array}$ & $\begin{array}{l}0.07 \\
(0.9)\end{array}$ & $\begin{array}{l}0.03 \\
(0.3)\end{array}$ & $\begin{array}{l}-0.04 \\
-(0.6)\end{array}$ & $\begin{array}{l}-0.09 \\
-(1.1)\end{array}$ & $\begin{array}{l}0.08 \\
(1.0)\end{array}$ & $\begin{array}{l}-0.08 \\
-(1.0)\end{array}$ & $\begin{array}{l}-0.04 \\
-(0.4)\end{array}$ & $\begin{array}{l}-0.04 \\
-(0.4)\end{array}$ & $\begin{array}{l}-0.12 \\
-(1.4)\end{array}$ \\
\hline $36-45$ & $\begin{array}{l}0.04 \\
(0.5)\end{array}$ & $\begin{array}{l}0.07 \\
(0.8)\end{array}$ & $\begin{array}{l}0.05 \\
(0.5)\end{array}$ & $\begin{array}{l}0.02 \\
(0.2)\end{array}$ & $\begin{array}{l}0.00 \\
(0.0)\end{array}$ & $\begin{array}{l}0.00 \\
(0.0)\end{array}$ & $\begin{array}{l}0.00 \\
(0.0)\end{array}$ & $\begin{array}{l}-0.02 \\
-(0.2)\end{array}$ & $\begin{array}{l}0.27 \\
(2.7)\end{array}$ & $\begin{array}{c}0.18 \\
(1.9)\end{array}$ \\
\hline $46-55$ & $\begin{array}{l}0.10 \\
(1.0)\end{array}$ & $\begin{array}{l}0.12 \\
(0.9)\end{array}$ & $\begin{array}{l}0.10 \\
(0.7)\end{array}$ & $\begin{array}{l}-0.04 \\
-(0.3)\end{array}$ & $\begin{array}{l}0.05 \\
(0.4)\end{array}$ & $\begin{array}{l}-0.21 \\
-(1.3)\end{array}$ & $\begin{array}{l}-0.12 \\
-(0.8)\end{array}$ & $\begin{array}{l}-0.11 \\
-(0.8)\end{array}$ & $\begin{array}{l}-0.04 \\
-(0.2)\end{array}$ & $\begin{array}{l}0.03 \\
(0.2)\end{array}$ \\
\hline $56-65$ & $\begin{array}{l}-0.07 \\
-(0.5)\end{array}$ & $\begin{array}{l}-0.28 \\
-(1.0)\end{array}$ & $\begin{array}{l}-0.44 \\
-(1.4)\end{array}$ & $\begin{array}{l}0.14 \\
(0.6)\end{array}$ & $\begin{array}{l}0.16 \\
(0.5)\end{array}$ & $\begin{array}{l}0.13 \\
(0.4)\end{array}$ & $\begin{array}{l}0.29 \\
(1.1)\end{array}$ & $\begin{array}{l}0.29 \\
(1.2)\end{array}$ & $\begin{array}{l}-0.05 \\
-(0.2)\end{array}$ & $\begin{array}{l}-0.02 \\
-(0.1)\end{array}$ \\
\hline \multicolumn{11}{|l|}{ Education } \\
\hline Higher & $\begin{array}{l}0.05 \\
(0.5)\end{array}$ & $\begin{array}{l}-0.21 \\
-(2.0)\end{array}$ & $\begin{array}{l}-0.25 \\
-(2.0)\end{array}$ & $\begin{array}{l}-0.03 \\
-(0.2)\end{array}$ & $\begin{array}{l}0.02 \\
(0.2)\end{array}$ & $\begin{array}{l}0.02 \\
(0.2)\end{array}$ & $\begin{array}{c}0.03 \\
(0.2)\end{array}$ & $\begin{array}{l}0.03 \\
(0.2)\end{array}$ & $\begin{array}{c}0.04 \\
(0.3)\end{array}$ & $\begin{array}{l}-0.08 \\
-(0.6)\end{array}$ \\
\hline Higher vocational & $\begin{array}{l}-0.16 \\
-(1.4)\end{array}$ & $\begin{array}{l}-0.04 \\
-(0.3)\end{array}$ & $\begin{array}{l}0.08 \\
(0.6)\end{array}$ & $\begin{array}{l}-0.04 \\
-(0.3)\end{array}$ & $\begin{array}{c}0.01 \\
(0.0)\end{array}$ & $\begin{array}{l}0.13 \\
(0.8)\end{array}$ & $\begin{array}{l}0.10 \\
(0.6)\end{array}$ & $\begin{array}{l}0.03 \\
(0.2)\end{array}$ & $\begin{array}{l}-0.44 \\
-(2.5)\end{array}$ & $\begin{array}{l}-0.25 \\
-(1.5)\end{array}$ \\
\hline Advanced high school & $\begin{array}{l}0.37 \\
(2.9)\end{array}$ & $\begin{array}{l}0.27 \\
(1.8)\end{array}$ & $\begin{array}{c}0.24 \\
(1.5)\end{array}$ & $\begin{array}{l}0.16 \\
(1.1)\end{array}$ & $\begin{array}{l}-0.08 \\
-(0.5)\end{array}$ & $\begin{array}{l}0.17 \\
(1.0)\end{array}$ & $\begin{array}{l}0.14 \\
(0.9)\end{array}$ & $\begin{array}{l}0.09 \\
(0.5)\end{array}$ & $\begin{array}{l}-0.19 \\
-(1.1)\end{array}$ & $\begin{array}{l}0.19 \\
(1.2)\end{array}$ \\
\hline Apprenticeship & $\begin{array}{l}-0.03 \\
-(0.7)\end{array}$ & $\begin{array}{l}0.01 \\
(0.2)\end{array}$ & $\begin{array}{l}0.01 \\
(0.1)\end{array}$ & $\begin{array}{l}-0.01 \\
-(0.3)\end{array}$ & $\begin{array}{l}0.07 \\
(1.2)\end{array}$ & $\begin{array}{l}0.03 \\
(0.6)\end{array}$ & $\begin{array}{l}0.03 \\
(0.6)\end{array}$ & $\begin{array}{l}0.00 \\
(0.0)\end{array}$ & $\begin{array}{l}0.09 \\
(1.6)\end{array}$ & $\begin{array}{l}0.01 \\
(0.1)\end{array}$ \\
\hline Mandatory or less & $\begin{array}{l}0.04 \\
(0.6)\end{array}$ & $\begin{array}{l}-0.01 \\
-(0.1)\end{array}$ & $\begin{array}{l}-0.05 \\
-(0.5)\end{array}$ & $\begin{array}{l}0.02 \\
(0.3)\end{array}$ & $\begin{array}{l}-0.16 \\
-(1.4)\end{array}$ & $\begin{array}{l}-0.21 \\
-(1.9)\end{array}$ & $\begin{array}{l}-0.19 \\
-(1.7)\end{array}$ & $\begin{array}{l}-0.05 \\
-(0.4)\end{array}$ & $\begin{array}{l}0.08 \\
(0.7)\end{array}$ & $\begin{array}{l}0.10 \\
(1.0)\end{array}$ \\
\hline Gender & & & & & & & & & & \\
\hline Female & $\begin{array}{l}-0.06 \\
-(1.3)\end{array}$ & $\begin{array}{l}-0.11 \\
-(2.0)\end{array}$ & $\begin{array}{l}0.01 \\
(0.2)\end{array}$ & $\begin{array}{l}0.04 \\
(0.7)\end{array}$ & $\begin{array}{l}0.12 \\
(1.8)\end{array}$ & $\begin{array}{l}0.17 \\
(2.8)\end{array}$ & $\begin{array}{l}0.15 \\
(2.4)\end{array}$ & $\begin{array}{l}0.05 \\
(0.9)\end{array}$ & $\begin{array}{l}0.07 \\
(1.1)\end{array}$ & $\begin{array}{l}0.10 \\
(1.5)\end{array}$ \\
\hline Male & $\begin{array}{l}0.05 \\
(1.3)\end{array}$ & $\begin{array}{c}0.08 \\
(2.0)\end{array}$ & $\begin{array}{l}-0.01 \\
-(0.2)\end{array}$ & $\begin{array}{l}-0.03 \\
-(0.7)\end{array}$ & $\begin{array}{l}-0.09 \\
-(1.8)\end{array}$ & $\begin{array}{l}-0.13 \\
-(2.8)\end{array}$ & $\begin{array}{l}-0.11 \\
-(2.4)\end{array}$ & $\begin{array}{l}-0.04 \\
-(0.9)\end{array}$ & $\begin{array}{l}-0.05 \\
-(1.1)\end{array}$ & $\begin{array}{l}-0.07 \\
-(1.5)\end{array}$ \\
\hline Region of Residence & & & & & & & & & & \\
\hline German part & $\begin{array}{l}0.03 \\
(1.6)\end{array}$ & $\begin{array}{l}-0.02 \\
-(0.9)\end{array}$ & $\begin{array}{l}-0.01 \\
-(0.3)\end{array}$ & $\begin{array}{l}-0.04 \\
-(1.6)\end{array}$ & $\begin{array}{l}-0.04 \\
-(1.2)\end{array}$ & $\begin{array}{l}-0.03 \\
-(1.1)\end{array}$ & $\begin{array}{l}-0.05 \\
-(1.6)\end{array}$ & $\begin{array}{l}-0.05 \\
-(1.7)\end{array}$ & $\begin{array}{l}-0.02 \\
-(0.7)\end{array}$ & $\begin{array}{l}-0.01 \\
-(0.5)\end{array}$ \\
\hline Latin part & $\begin{array}{r}-0.09 \\
-(1.6) \\
\end{array}$ & $\begin{array}{r}0.06 \\
(0.9)\end{array}$ & $\begin{array}{l}0.02 \\
(0.3)\end{array}$ & $\begin{array}{l}0.11 \\
(1.6)\end{array}$ & $\begin{array}{r}0.10 \\
(1.2)\end{array}$ & $\begin{array}{l}0.09 \\
(1.1)\end{array}$ & $\begin{array}{l}0.13 \\
(1.6)\end{array}$ & $\begin{array}{l}0.14 \\
(1.7)\end{array}$ & $\begin{array}{l}0.06 \\
(0.7)\end{array}$ & $\begin{array}{c}0.04 \\
(0.5)\end{array}$ \\
\hline \# persons & 14,144 & 17,034 & 18,609 & 28,742 & 20,517 & 20,585 & 20,764 & 21,616 & 21,526 & 22,079 \\
\hline \# observations & 21,156 & 21,786 & 21,656 & 30,174 & 20,517 & 20,585 & 20,764 & 21,616 & 21,526 & 22,079 \\
\hline
\end{tabular}

Source: Swiss Labor Force Survey; own calculations. 


\section{Figure 1: Unemployment and Employment Rates}

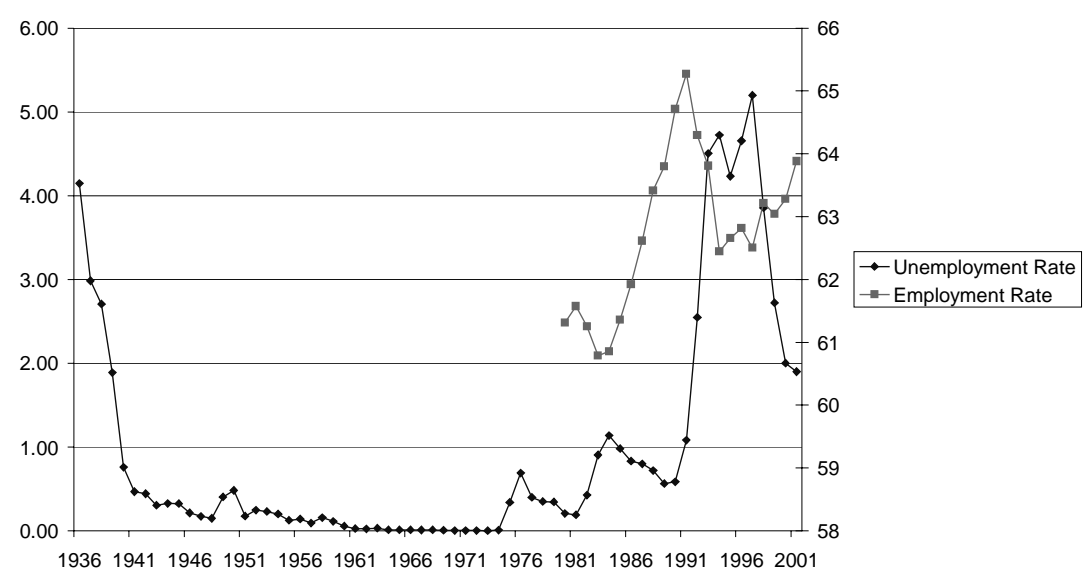

Year

Source: Bundesamt für Statistik (Swiss Federal Statistical Office).

\section{Figure 2: $\quad$ OECD Macroeconomic Time Series}

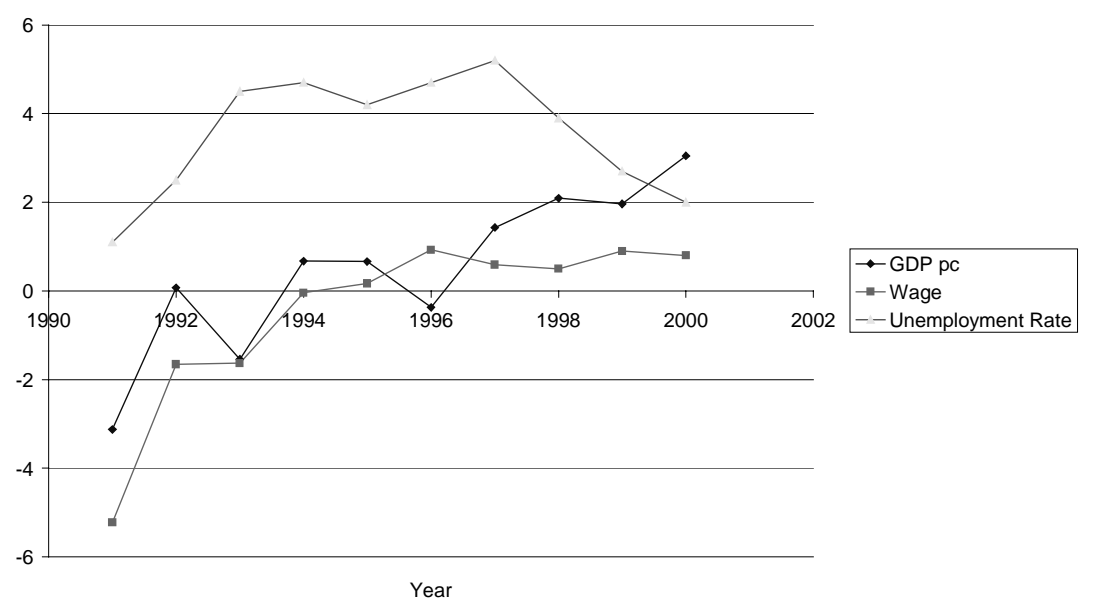

Note: GDP per capita growth rates are deflated by the OECD's GDP implicit price level; so are the wage series which refer to hourly earnings in manufacturing; the unemployment rate is the OECD standardised unemployment rate.
Figure 3: Constant Demand and 'Market' Relative Wage Simulations

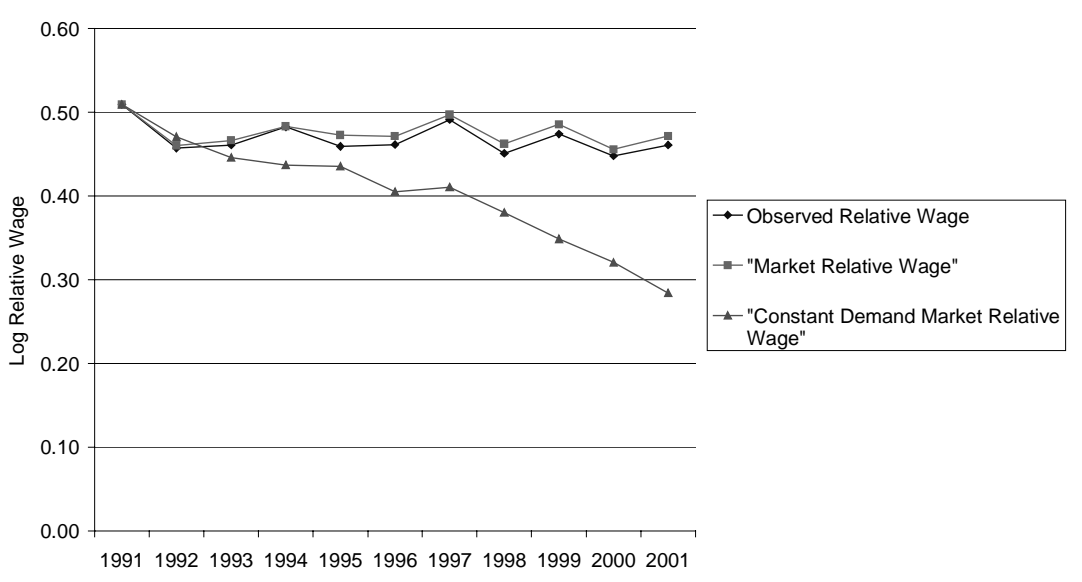

Year / Quarter

Figure 4: $\quad$ Relative Wage Simulations under Alternative Immigrant Regimes

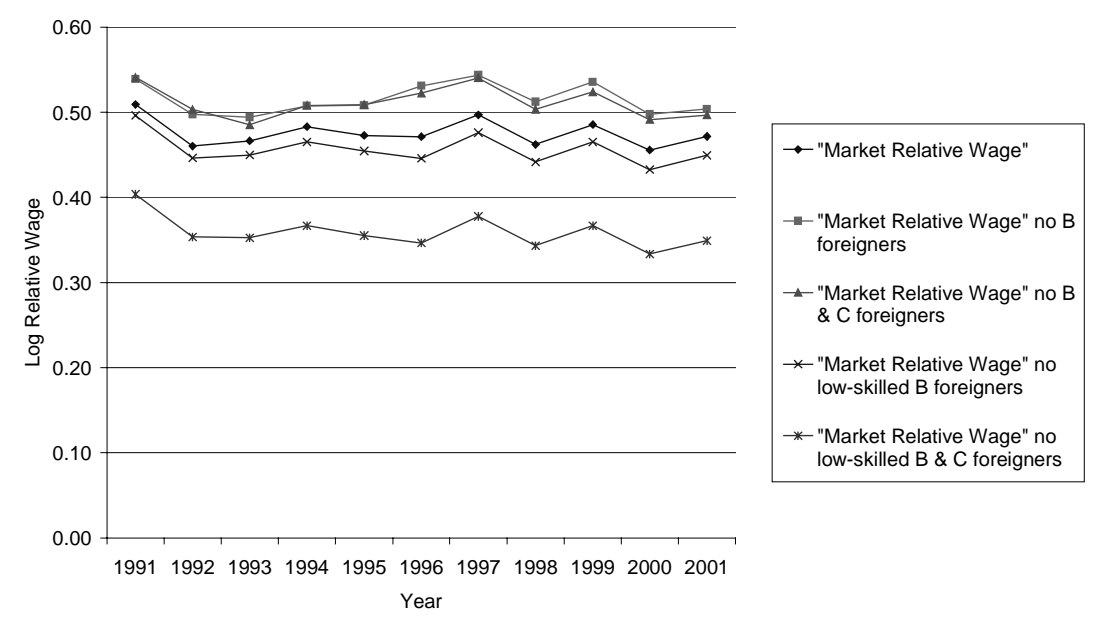


Figure 5a: Wage Regression - Age Coefficients over Time

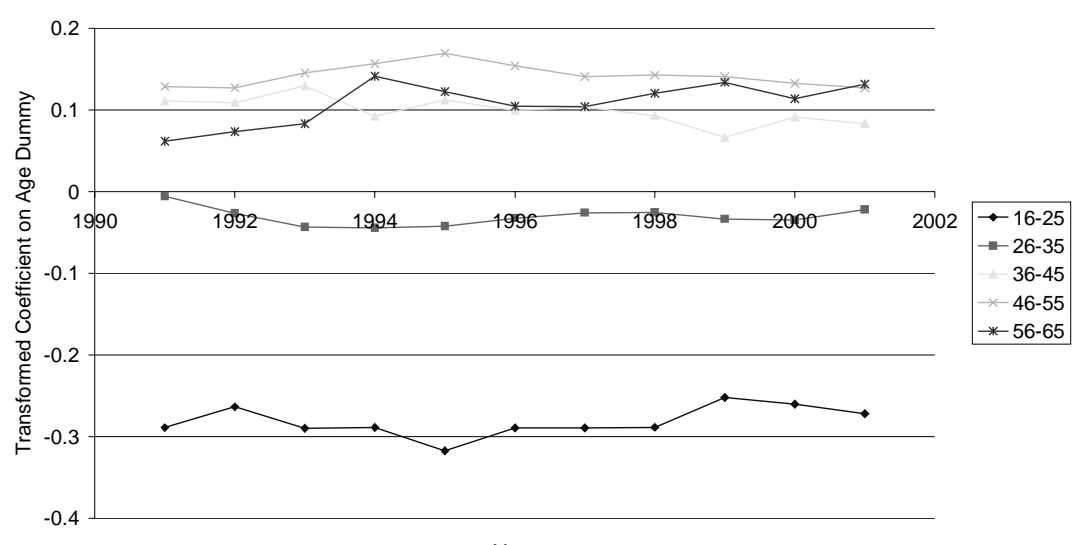

Figure 5b: Unemployment Regression - Age Coefficients over Time

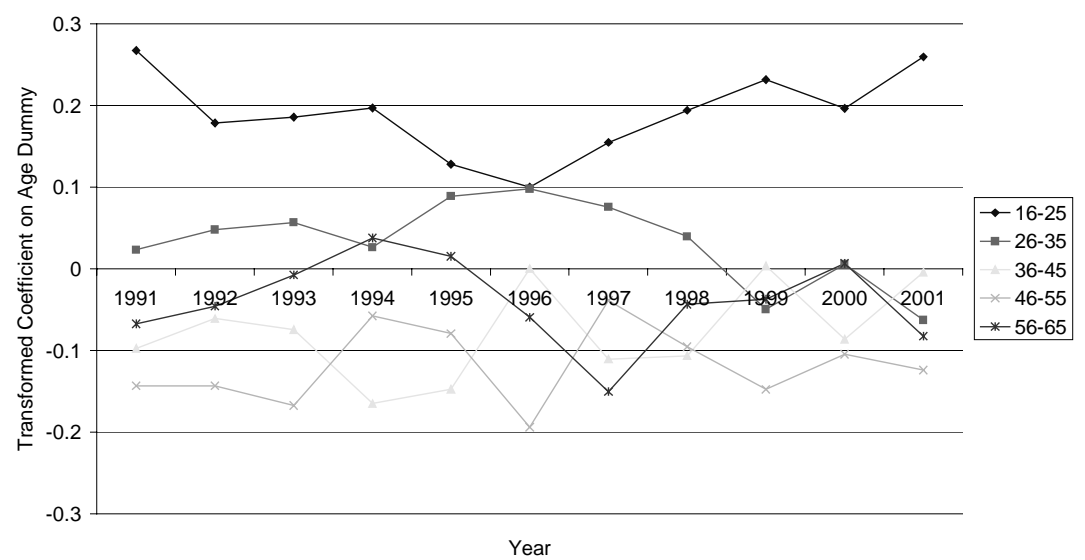

Figure 5c: Non-Employment Regression - Age Coefficients over Time

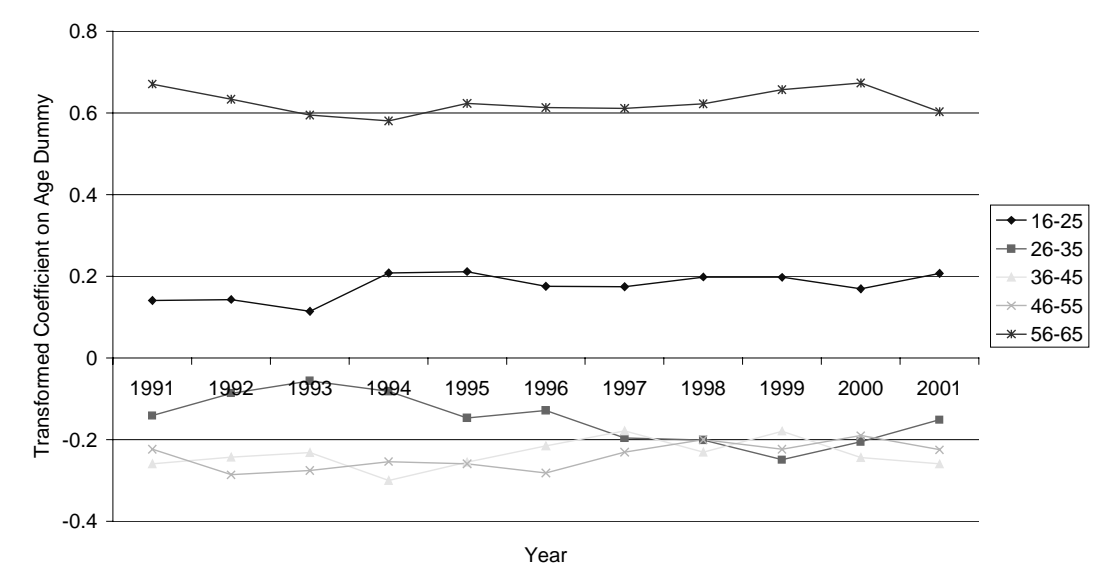

Figure 5d: Temporary Immigrant Regression - Age Coefficients over Time

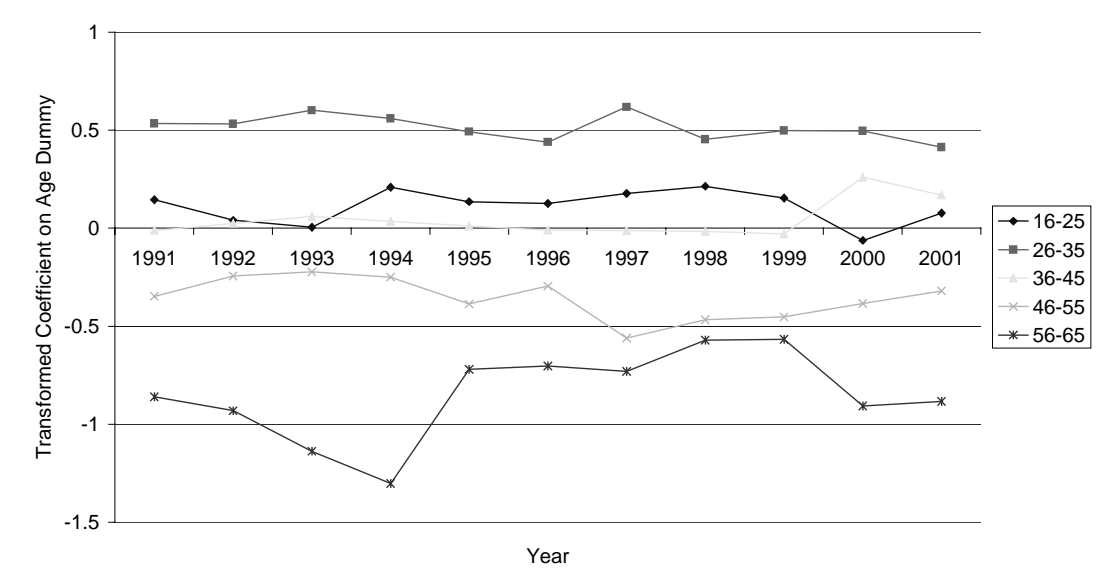


Figure 6a: Wage Regression - Education Coefficients over Time

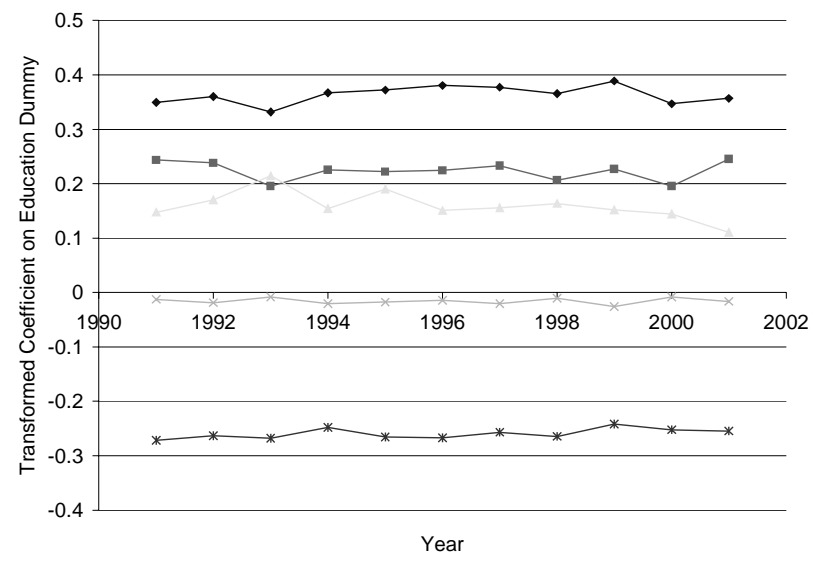

Figure 6b: Unemployment Regression Coefficients over Time

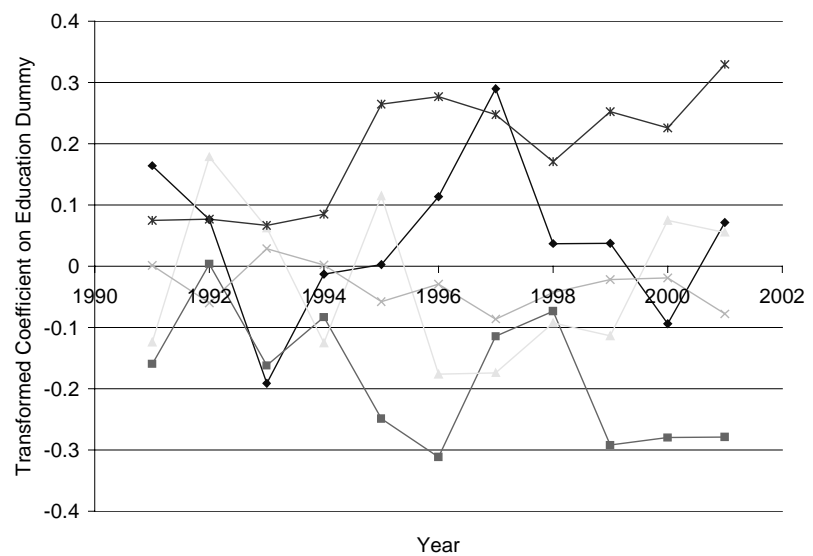

Figure 6c: Non-Employment Regression Coefficients over Time

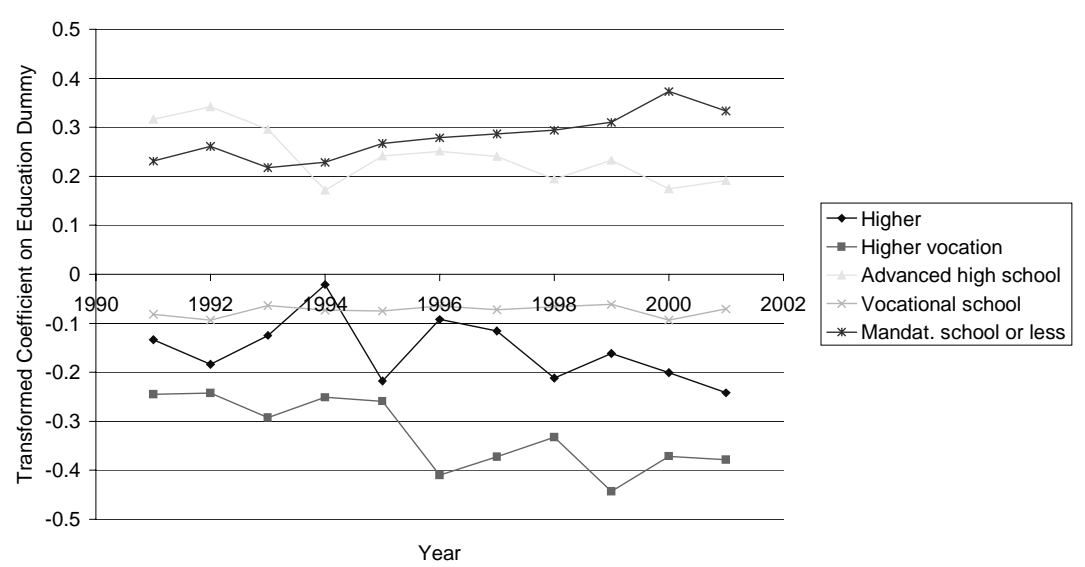

Figure 6d: Temporary Immigrant Regression - Education Coefficients over Time

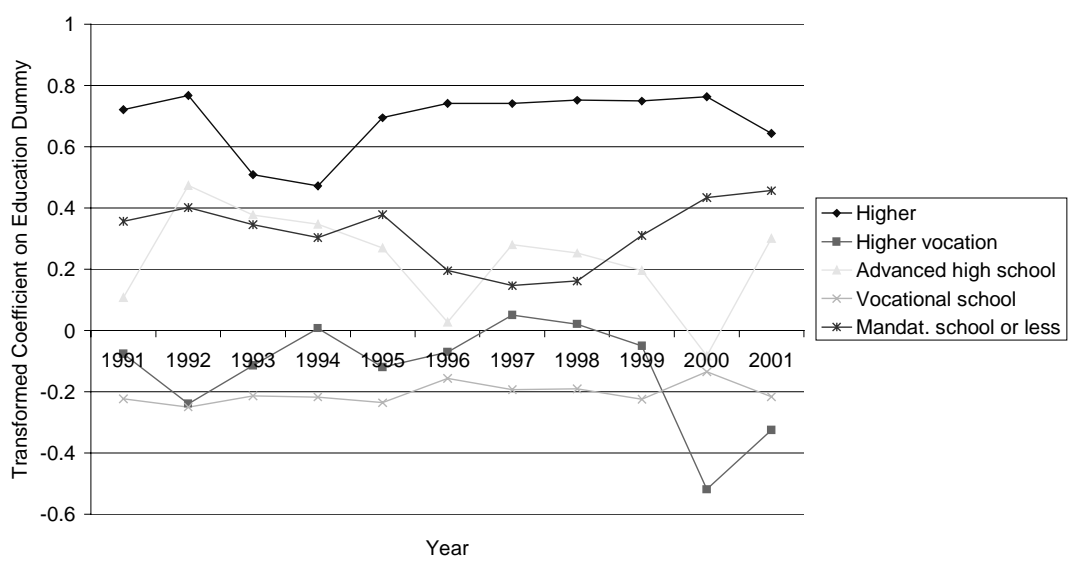




\section{Appendix A}

\section{Theoretical justification for the empirical approach in Section 5}

In order to identify relative net demand shocks, I adapt Katz and Autor's (1999) supply-demandinstitutions framework. The framework rests on a neoclassical model of the labour market:

$$
\begin{array}{ll}
S_{t}=S_{t}\left(\mathcal{W}_{t}, \mathcal{Z}_{t}\right) & (L \times 1 \text { vector of labour supplies }) \\
D_{t}=D_{t}\left(\mathcal{W}_{t}, \mathcal{Z}_{t},\right) & (L \times 1 \text { vector of labour demands })
\end{array}
$$

where $D_{t}$ and $S_{t}$ denote vectors of labour demand and supply for $L$ different labour markets, respectively. $\mathcal{W}_{t}$ is a vector of wage rates and $\mathcal{Z}_{t}$ is a vector of demand and/or supply 'shift factors', which subsumes a wide range of aspects such as the permanently resident labour force, the share of temporary work permit holders in the labour force, technological change, foreign demand for Swiss goods, or the preference structure of the population.

In the face of a negative relative demand shock (formally defined below), a real wage rigidity will cause quantity rationing in the form of unemployment (or non-employment). This is the same conceptual set up as in the studies by Nickell and Bell (1996) and Gottschalk and Joyce (1997). Formally, unemployment due to rigid wages can be expressed as a function of the vector of wage rates and supply/demand shift factors as

$$
\mathcal{U}_{\text {rigid }, t}=\frac{\left(S_{t}-D_{t}\right)}{S_{t}}=1-\frac{D_{t}\left(\mathcal{W}_{t}, \mathcal{Z}_{t}\right)}{S_{t}\left(\mathcal{W}_{t}, \mathcal{Z}_{t}\right)}=\mathcal{U}_{\text {rigid }, t}\left(\mathcal{W}_{t}, \mathcal{Z}_{t}\right)
$$

( $L \times 1$ vector of latent unemployment rates).

Because transaction costs or incomplete information may induce market frictions, the observed unemployment rate may be higher than the unemployment rate component due to rigid 
wages. This issue has not been addressed in related papers by Card, Kramarz, and Lemieux (1999) or Krueger and Pischke (1997), probably because an empirically tractable model of unemployment with wage rigidities in a search context has not been developed yet. Here, I will at least state the condition for the frictional unemployment component to be ignorable. Formally, one can write the observed unemployment rate as

$$
\mathcal{U}_{\text {observed }, t}=\varphi_{t}\left(\mathcal{U}_{\text {rigid }, t}, \delta_{t}\right)
$$

( $L \times 1$ vector of observed unemployment rates)

where $\delta_{t}$ is the frictional component of unemployment, which may be affected by changes in the unemployment benefit regime ( $c f$. Section 2). This frictional component can be ignored for the analysis of this paper if between any two points in time $t$ and $t+\tau$

$$
\operatorname{sgn}\left(\Delta_{t}^{t+\tau} \mathcal{U}_{\text {observed }}^{l}\right)=\operatorname{sgn}\left(\Delta_{t}^{t+\tau} \mathcal{U}_{\text {rigid }}^{l}\right) \quad \forall l
$$

holds, which means that the frictional component is not exogenously changing the observed unemployment rate. Imposing this restriction and using a Taylor expansion one obtains

$$
\operatorname{sgn}\left(\Delta_{t}^{t+\tau} \mathcal{U}_{\text {observed }}^{l}\right) \approx \operatorname{sgn}(\underbrace{\mathcal{U}_{\mathcal{W}}^{l, l} \cdot \Delta_{t}^{t+\tau} \mathcal{W}^{l}}_{\text {own wage effect }}+\underbrace{\sum_{j \neq l}^{\sum_{\mathcal{W}}^{l, j} \cdot \Delta_{t}^{t+\tau} \mathcal{W}^{j}}}_{\text {cross wage effects }}+\underbrace{\sum_{j} \mathcal{U}_{\mathcal{Z}}^{l, j} \cdot \Delta_{t}^{t+\tau} \mathcal{Z}^{j}}_{\text {pure net supply shift effects }})
$$

where $\mathcal{U}_{\mathcal{W}}^{l, l}, \mathcal{U}_{\mathcal{W}}^{l, j}$, and $\mathcal{U}_{\mathcal{Z}}^{l, j}$ are elements of the Jacobian derivative of $\mathcal{U}_{\text {rigid }}$ referring to the own wage (the wage in the same labour market), the wages in other labour markets, and the demand/supply shift factors, respectively.

Economic theory allows to impose a light restriction, which is helpful for identification in the econometric analysis: if labour supply and demand schedules are 'upward' and 'downward 
sloping', respectively, then $\mathcal{U}_{\mathcal{W}}^{l, l}$ will be positive, because a ceteris paribus increase of the ownwage will increase unemployment in the corresponding labour market. $\mathcal{U}_{\mathcal{W}}^{l, l}$ will also be positive in other cases, one of them being 'backward-bending' labour supply behaviour in case the slope of the demand curve is less steep than the one of the supply curve and there is no excess demand for labour. It therefore seems innocuous to impose the restriction that $\mathcal{U}_{\mathcal{W}}^{l, l}$ is positive.

As to the sign of the cross-wage effects $\mathcal{U}_{\mathcal{W}}^{l, j}$, economic theory has little to say. This is also true for the sign of the derivative of unemployment with respect to the supply/demand shift variables, $\mathcal{U}_{\mathcal{Z}}^{l, j}$, as these variables subsume a wide range of unspecified factors. Note that - unlike in the macro approach of Section 4 - no assumption is made on the size of substitution or any other demand or supply elasticities. These weak assumptions come at the price of not being able to measure demand or supply shocks and wage rigidity quantitatively. However, as can be deduced from equation (A3), observations on the signs of the changes in wage and unemployment rates between two points in time identify the sign of the change in the net supply shift effect (i.e. the net supply shock)

$$
\xi=\underbrace{\sum_{j \neq l} \mathcal{U}_{\mathcal{W}}^{l, j} \cdot \Delta_{t}^{t+\tau} \mathcal{W}^{j}+\sum_{j} \mathcal{U}_{\mathcal{Z}}^{l, j} \cdot \Delta_{t}^{t+\tau} \mathcal{Z}^{j}}_{\text {net supply shift effects }}
$$

in 7 out of 9 cases (distinguished by the sign of wage and unemployment changes, similarly as in Table 3 in the text) ( $c f$. Puhani, 2001). Note that a negative net demand shock is equivalent to a positive net supply shock, i.e. $\xi>0$. I argue that such a qualitative empirical approach with comparatively few assumptions provides a valuable and robust tool for gaining insights into the existence of wage rigidities. 
However, the question posed by the Krugman hypothesis (1994) is not whether lowskilled workers experienced a negative net demand shock, but whether they faced a relative negative net demand shock. A relative negative net demand shock for a labour market $l$ means that the net demand shock experienced by this market is more negative than the one affecting the reference market $r$ (the latter refers to an 'average' market and is defined to be the 1991 sample mean of the labour force in this paper). Identification of relative net demand (or supply) shocks is based on observing relative wage and unemployment changes: $\Delta_{t}^{t+\tau} \mathcal{W}^{l}-\Delta_{t}^{t+\tau} \mathcal{W}^{r}$ and $\Delta_{t}^{t+\tau} \mathcal{U}_{\text {observed }}^{l}-\Delta_{t}^{t+\tau} \mathcal{U}_{\text {observed }}^{r}$

In order to identify relative negative net demand shocks note that

$$
\begin{aligned}
& \Delta_{t}^{t+\tau} \mathcal{U}_{\text {observed }}^{l}-\Delta_{t}^{t+\tau} \mathcal{U}_{\text {observed }}^{r}= \\
& \varphi_{t+\tau}^{l}\left(\mathcal{U}_{\text {rigid }, t+\tau}^{l}, \delta_{t+\tau}^{l}\right)-\varphi_{t}^{l}\left(\mathcal{U}_{\text {rigid }, t}^{l}, \delta_{t}^{l}\right)-\varphi_{t+\tau}^{r}\left(\mathcal{U}_{\text {rigid }, t+\tau}^{r}, \delta_{t+\tau}^{r}\right)+\varphi_{t}^{r}\left(\mathcal{U}_{\text {rigid }, t}^{r}, \delta_{t}^{r}\right)
\end{aligned}
$$

where $r$ denotes the reference market with respect to which the wage and unemployment structure is defined. For the frictional components $\delta$ of unemployment to be ignorable for identification, it has to be the case that

$$
\operatorname{sgn}\left(\Delta_{t}^{t+\tau} \mathcal{U}_{\text {observed }}^{l}-\Delta_{t}^{t+\tau} \mathcal{U}_{\text {observed }}^{r}\right)=\operatorname{sgn}\left(\Delta_{t}^{t+\tau} \mathcal{U}_{\text {rigid }}^{l}-\Delta_{t}^{t+\tau} \mathcal{U}_{\text {rigid }}^{r}\right)
$$

Take the following example to gain some intuition for this condition: let the function $\varphi(\bullet)$ be additive for all labour markets at all time periods. Then the change in the observed unemployment structure can be written as

$$
\Delta_{t}^{t+\tau} \mathcal{U}_{\text {observed }}^{l}-\Delta_{t}^{t+\tau} \mathcal{U}_{\text {observed }}^{r}=\Delta_{t}^{t+\tau} \mathcal{U}_{\text {rigid }}^{r}-\Delta_{t}^{t+\tau} \mathcal{U}_{\text {rigid }}^{r}+\Delta_{t}^{t+\tau} \delta^{l}-\Delta_{t}^{t+\tau} \delta^{r}
$$

The condition for frictional unemployment to be ignorable then becomes

$$
\operatorname{sgn}\left(\Delta_{t}^{t+\tau} \mathcal{U}_{\text {rigid }}^{r}-\Delta_{t}^{t+\tau} \mathcal{U}_{\text {rigid }}^{r}+\Delta_{t}^{t+\tau} \delta^{l}-\Delta_{t}^{t+\tau} \delta^{r}\right)=\operatorname{sgn}\left(\Delta_{t}^{t+\tau} \mathcal{U}_{\text {rigid }}^{l}-\Delta_{t}^{t+\tau} \mathcal{U}_{\text {rigid }}^{r}\right)
$$


In words, this means that relative changes in the frictional components of unemployment must not dominate relative changes in unemployment due to wage rigidities. Fulfilment of this condition is plausible if there are no institutional or technological shocks to the labour market which have a major impact on the search process of unemployed people or firms trying to fill vacancies. I argue in the text of the paper that the timing of the unemployment benefit reforms makes it implausible that the results of Section 5.2 are driven by changes in frictional unemployment.

Note also that the condition for the identification of absolute net demand shocks, $\operatorname{sgn}\left(\Delta_{t}^{t+\tau} \mathcal{U}_{\text {observed }}^{l}\right)=\operatorname{sgn}\left(\Delta_{t}^{t+\tau} \mathcal{U}_{\text {rigid }}^{l}\right)$, and the one for the identification of relative net demand shocks $\operatorname{sgn}\left(\Delta_{t}^{t+\tau} \mathcal{U}_{\text {observed }}^{l}-\Delta_{t}^{t+\tau} \mathcal{U}_{\text {observed }}^{r}\right)=\operatorname{sgn}\left(\Delta_{t}^{t+\tau} \mathcal{U}_{\text {rigid }}^{l}-\Delta_{t}^{t+\tau} \mathcal{U}_{\text {rigid }}^{r}\right), \quad$ are not nested. The identification of relative net demand shocks also requires an additional assumption, namely $\mathcal{U}_{\mathcal{W}}^{l, l} \approx \mathcal{U}_{\mathcal{W}}^{r, r}$. Using a Taylor approximation as for the derivation of (A3) one can write:

$$
\begin{aligned}
& \Delta_{t}^{t+\tau} \mathcal{U}_{\text {rigid }}^{l}-\Delta_{t}^{t+\tau} \mathcal{U}_{\text {rigid }}^{r} \approx \\
& \mathcal{U}_{\mathcal{W}}^{l, l} \cdot \Delta_{t}^{t+\tau} \mathcal{W}^{l}-\mathcal{U}_{\mathcal{W}}^{r, r} \cdot \Delta_{t}^{t+\tau} \mathcal{W}^{r}+\sum_{j \neq l} \mathcal{U}_{\mathcal{W}}^{l, j} \cdot \Delta_{t}^{t+\tau} \mathcal{W}^{j}-\sum_{j \neq r} \mathcal{U}_{\mathcal{W}}^{r, j} \cdot \Delta_{t}^{t+\tau} \mathcal{W}^{j}+ \\
& \sum_{j} \mathcal{U}_{\mathcal{Z}}^{l, j} \cdot \Delta_{t}^{t+\tau} \mathcal{Z}^{j}-\sum_{j} \mathcal{U}_{\mathcal{Z}}^{r, j} \cdot \Delta_{t}^{t+\tau} \mathcal{Z}^{j}
\end{aligned}
$$

Imposing $\mathcal{U}_{\mathcal{W}}^{l, l} \approx \mathcal{U}_{\mathcal{W}}^{r, r}$, which means that the own-wage effects on unemployment are similar in labour market $l$ and reference market $r$, yields:

$$
\operatorname{sgn}\left(\Delta_{t}^{t+\tau} \mathcal{U}_{\text {observed }}^{l}-\Delta_{t}^{t+\tau} \mathcal{U}_{\text {observed }}^{r}\right)=\operatorname{sgn}\left(\begin{array}{l}
\mathcal{U}_{\mathcal{W}}^{l, l}\left[\Delta_{t}^{t+\tau} \mathcal{W}^{l}-\Delta_{t}^{t+\tau} \mathcal{W}^{r}\right]+ \\
\sum_{j \neq l} \mathcal{U}_{\mathcal{W}}^{l, j} \cdot \Delta_{t}^{t+\tau} \mathcal{W}^{j}-\sum_{j \neq r} \mathcal{U}_{\mathcal{W}}^{r, j} \cdot \Delta_{t}^{t+\tau} \mathcal{W}^{j}+ \\
\sum_{j} \mathcal{U}_{\mathcal{Z}}^{l, j} \cdot \Delta_{t}^{t+\tau} \mathcal{Z}^{j}-\sum_{j} \mathcal{U}_{\mathcal{Z}}^{r, j} \cdot \Delta_{t}^{t+\tau} \mathcal{Z}^{j}
\end{array}\right)
$$


Hence, by observing relative wage and unemployment changes, $\Delta_{t}^{t+\tau} \mathcal{W}^{l}-\Delta_{t}^{t+\tau} \mathcal{W}^{r}$ and $\Delta_{t}^{t+\tau} \mathcal{U}_{\text {observed }}^{l}-\Delta_{t}^{t+\tau} \mathcal{U}_{\text {observed }}^{r}$, and noting that equation (A5) holds, the sign of the relative net supply shock

$$
\xi^{l, r}=\sum_{j \neq l} \mathcal{U}_{\mathcal{W}}^{l, j} \cdot \Delta_{t}^{t+\tau} \mathcal{W}^{j}-\sum_{j \neq r} \mathcal{U}_{\mathcal{W}}^{r, j} \cdot \Delta_{t}^{t+\tau} \mathcal{W}^{j}+\sum_{j} \mathcal{U}_{\mathcal{Z}}^{l, j} \cdot \Delta_{t}^{t+\tau} \mathcal{Z}^{j}-\sum_{j} \mathcal{U}_{\mathcal{Z}}^{r, j} \cdot \Delta_{t}^{t+\tau} \mathcal{Z}^{j}
$$

(which is the negative of the relative net demand shock) can be identified.

\section{Empirical Implementation}

In order to take the concepts described above to the data, I define a labour market $l$ by its characteristics $\mathbf{x}_{l}$ (see Section 3 for a variable description; the subscript $l$ shall be dropped henceforth), and denote the reference labour market $r$ by $\overline{\mathbf{x}} . \mathcal{W}$ and $\mathcal{U}$ are defined as expected values of the wage rate $W$ and the unemployment indicator $U=1$ (unemployed), respectively. $1(\bullet)$ is the indicator function which takes on value 1 if the argument is true and 0 otherwise.

Hence I define

$$
\begin{aligned}
& {\left[\Delta_{t}^{t+\tau} \mathcal{W}^{l}-\Delta_{t}^{t+\tau} \mathcal{W}^{r}\right] \equiv E\left[W_{t+\tau}-W_{t} \mid \mathbf{x}\right]-E\left[W_{t+\tau}-W_{t} \mid \overline{\mathbf{x}}\right]} \\
& {\left[\Delta_{t}^{t+\tau} \mathcal{U}_{\text {observed }}^{l}-\Delta_{t}^{t+\tau} \mathcal{U}_{\text {observed }}^{r}\right] \equiv E\left[U_{t+\tau}-U_{t} \mid \mathbf{x}\right]-E\left[U_{t+\tau}-U_{t} \mid \overline{\mathbf{x}}\right] .}
\end{aligned}
$$

In order to identify labour market characteristics associated with relative wage or unemployment changes, I parameterise the distributions of $W$ and $U$ in the following way:

$$
\begin{aligned}
& E\left[\ln W_{t} \mid \mathbf{x}\right]=\mathbf{x} \boldsymbol{\beta}_{t} \\
& E\left[U_{t} \mid \mathbf{x}\right]=\Phi\left(\mathbf{x} \boldsymbol{\gamma}_{t}\right)
\end{aligned}
$$


where $\Phi(\bullet)$ denotes the cumulative distribution function of the standard normal distribution. A transformed version of the (dummy variable) coefficients of these non-linear parametric regression models can form the basis for the classification of each labour market characteristic $x_{k}$ (e.g. low level of education) to its contribution to relative wage and unemployment changes. This contribution is measured by the changes in the transformed coefficients (denoted by an asterisk) over time: $\left(\beta_{t+\tau, k}^{*}-\beta_{t, k}^{*}\right)$ and $\left(\gamma_{t+\tau, k}^{*}-\gamma_{t, k}^{*}\right)$, respectively. The transformed coefficients (as well as their standard errors) are calculated as in Haisken-De New and Schmidt (1997): $\boldsymbol{\beta}_{t}^{*}=(\mathbf{I}-\mathbf{W}) \boldsymbol{\beta}_{t}$, $\boldsymbol{\gamma}_{t}^{*}=(\mathbf{I}-\mathbf{W}) \boldsymbol{\gamma}_{t}$, where $\mathbf{I}$ is the identity matrix and $\mathbf{W}$ is a matrix containing weights, which in my case will be 1991 sample means. This transformation sets the 'base category' for the dummy variables equal to the 1991 sample mean. It can be shown that due to the non-linearity of the loglinear wage regression and the probit model, this transformation is necessary to interpret changes in the coefficients over time as contributions to rising relative wages or unemployment likelihoods ( $c f$. Puhani, 2001). Hence, instead of classifying each conceivable labour market defined by all dummy variable groups, one can just classify each labour market characteristic $x_{k}$ into each of the nine cells defined in Table 3 in the text, depending on whether it contributed to a rising, constant, or falling relative wage or unemployment likelihood. This is the approach taken in Section 5 of the paper. 
Table A1: Weighted Sample Means for Unemployment Regressions (Percent)

\begin{tabular}{|c|c|c|c|c|c|c|c|c|c|c|c|}
\hline Variable & 1991 & 1992 & 1993 & 1994 & 1995 & 1996 & 1997 & 1998 & 1999 & 2000 & 2001 \\
\hline Unemployed & 1.7 & 2.5 & 3.5 & 3.6 & 3.0 & 3.7 & 4.1 & 3.6 & 3.0 & 2.6 & 2.5 \\
\hline \multicolumn{12}{|l|}{ Age } \\
\hline $16-25$ & 20 & 19 & 19 & 17 & 17 & 16 & 17 & 16 & 16 & 16 & 15 \\
\hline $26-35$ & 26 & 26 & 25 & 26 & 27 & 26 & 27 & 26 & 26 & 24 & 23 \\
\hline $36-45$ & 23 & 24 & 24 & 25 & 25 & 25 & 24 & 25 & 26 & 27 & 28 \\
\hline $46-55$ & 20 & 20 & 21 & 21 & 21 & 21 & 22 & 21 & 21 & 21 & 21 \\
\hline $56-65$ & 11 & 11 & 11 & 11 & 11 & 11 & 11 & 11 & 11 & 11 & 12 \\
\hline \multicolumn{12}{|l|}{ Education } \\
\hline Higher & 7 & 8 & 8 & 8 & 9 & 9 & 9 & 9 & 10 & 10 & 10 \\
\hline Higher vocational & 12 & 12 & 13 & 13 & 12 & 12 & 13 & 13 & 13 & 14 & 14 \\
\hline Advanced high school & 6 & 6 & 6 & 6 & 6 & 6 & 7 & 7 & 7 & 8 & 8 \\
\hline Apprenticeship & 54 & 54 & 53 & 53 & 53 & 54 & 53 & 52 & 51 & 51 & 50 \\
\hline Mandat. school or less & 21 & 20 & 21 & 21 & 20 & 19 & 19 & 19 & 19 & 18 & 18 \\
\hline \multicolumn{12}{|l|}{ Gender } \\
\hline Female & 43 & 43 & 43 & 43 & 43 & 44 & 44 & 44 & 44 & 44 & 45 \\
\hline Male & 57 & 57 & 57 & 57 & 57 & 56 & 56 & 56 & 56 & 56 & 55 \\
\hline \multicolumn{12}{|l|}{ Region of Residence } \\
\hline German part & 74 & 73 & 74 & 74 & 74 & 74 & 74 & 74 & 74 & 74 & 74 \\
\hline Latin part & 26 & 27 & 26 & 26 & 26 & 26 & 26 & 26 & 26 & 26 & 26 \\
\hline \# observations & 10,312 & 10,948 & 11,574 & 11,451 & 19,979 & 10,275 & 10,347 & 10,524 & 11,370 & 11,278 & 11,829 \\
\hline
\end{tabular}

Table A2: Weighted Temporary Immigrant Shares by Subgroup (Percent)

\begin{tabular}{|c|c|c|c|c|c|c|c|c|c|c|c|}
\hline Variable & 1991 & 1992 & 1993 & 1994 & 1995 & 1996 & 1997 & 1998 & 1999 & 2000 & 2001 \\
\hline Total sample & 3.4 & 4.0 & 4.1 & 4.0 & 4.6 & 6.0 & 5.3 & 5.6 & 5.2 & 4.9 & 5.2 \\
\hline \multicolumn{12}{|l|}{ Age } \\
\hline $16-25$ & 3.1 & 3.1 & 3.0 & 4.4 & 4.9 & 5.9 & 5.0 & 6.4 & 6.0 & 3.6 & 6.2 \\
\hline $26-35$ & 7.4 & 8.4 & 9.1 & 8.2 & 9.1 & 11.5 & 12.5 & 11.1 & 10.5 & 9.3 & 8.7 \\
\hline $36-45$ & 2.5 & 3.4 & 3.4 & 3.2 & 4.0 & 5.1 & 3.7 & 4.5 & 4.1 & 6.3 & 6.0 \\
\hline $46-55$ & 1.2 & 1.7 & 1.7 & 1.5 & 1.6 & 3.0 & 1.0 & 1.9 & 1.7 & 1.6 & 2.2 \\
\hline $56-65$ & 0.3 & 0.3 & 0.2 & 0.1 & 0.7 & 0.9 & 0.6 & 1.2 & 1.2 & 0.5 & 0.6 \\
\hline \multicolumn{12}{|l|}{ Education } \\
\hline Higher & 12.2 & 14.6 & 11.0 & 9.4 & 14.2 & 18.5 & 17.5 & 17.7 & 16.6 & 17.2 & 13.8 \\
\hline Higher vocational & 2.5 & 2.0 & 3.2 & 3.6 & 2.8 & 4.2 & 4.2 & 4.4 & 3.7 & 1.4 & 2.2 \\
\hline Advanced high school & 3.8 & 8.0 & 8.0 & 7.5 & 6.9 & 6.1 & 8.6 & 8.2 & 6.4 & 3.6 & 7.6 \\
\hline Apprenticeship & 1.8 & 1.8 & 2.3 & 2.2 & 2.3 & 3.8 & 3.0 & 3.2 & 2.7 & 2.9 & 2.6 \\
\hline Mandat. school or less & 5.2 & 5.8 & 5.6 & 5.6 & 7.3 & 7.3 & 5.7 & 6.4 & 7.1 & 7.2 & 8.6 \\
\hline \multicolumn{12}{|l|}{ Gender } \\
\hline Female & 2.7 & 2.8 & 2.7 & 3.4 & 4.1 & 6.1 & 6.0 & 6.1 & 4.8 & 4.6 & 5.2 \\
\hline Male & 3.9 & 4.9 & 5.1 & 4.4 & 5.0 & 6.0 & 4.8 & 5.3 & 5.6 & 5.2 & 5.1 \\
\hline \multicolumn{12}{|l|}{ Region of Residence } \\
\hline German part & 3.0 & 3.8 & 3.4 & 3.5 & 3.7 & 5.0 & 4.6 & 4.7 & 4.2 & 4.2 & 4.4 \\
\hline Latin part & 4.5 & 4.5 & 6.0 & 5.4 & 7.4 & 9.0 & 7.5 & 8.5 & 8.1 & 7.1 & 7.2 \\
\hline \# observations & 10,261 & 10,895 & 11,525 & 11,395 & 19,913 & 10,256 & 10,324 & 10,503 & 11,355 & 11,265 & 11,818 \\
\hline
\end{tabular}

Note: In 1995, the sample size of the SLFS was roughly doubled.

Source: Swiss Labour Force Survey; own calculations. 
Table A3: SLFS Wage Regressions (Changes in Transformed Coefficients with Respect to 1991 - Corresponding t-values in Parentheses)

\begin{tabular}{|c|c|c|c|c|c|c|c|c|c|c|}
\hline Variable & 1992 & 1993 & 1994 & 1995 & 1996 & 1997 & 1998 & 1999 & 2000 & 2001 \\
\hline \multirow[t]{2}{*}{1991 sample mean } & 0.03 & 0.03 & 0.04 & 0.02 & -0.01 & -0.01 & -0.01 & 0.01 & 0.00 & 0.02 \\
\hline & $(3.3)$ & (2.7) & $(3.9)$ & $(2.7)$ & $-(1.0)$ & $-(1.1)$ & $-(1.0)$ & $(0.7)$ & $(0.3)$ & $(1.7)$ \\
\hline \multicolumn{11}{|l|}{ Age } \\
\hline \multirow[t]{2}{*}{$16-25$} & 0.03 & 0.00 & 0.00 & -0.03 & 0.00 & 0.00 & 0.00 & 0.04 & 0.03 & 0.02 \\
\hline & $(1.2)$ & $(0.0)$ & $(0.0)$ & $-(1.3)$ & $(0.0)$ & $(0.0)$ & $(0.0)$ & $(1.6)$ & $(1.2)$ & $(0.8)$ \\
\hline \multirow[t]{2}{*}{$26-35$} & -0.02 & -0.04 & -0.04 & -0.04 & -0.03 & -0.02 & -0.02 & -0.03 & -0.03 & -0.02 \\
\hline & $-(1.7)$ & $-(2.8)$ & $-(3.1)$ & $-(2.9)$ & $-(1.9)$ & $-(1.5)$ & $-(1.5)$ & $-(2.0)$ & $-(2.2)$ & $-(1.3)$ \\
\hline \multirow[t]{2}{*}{$36-45$} & 0.00 & 0.02 & -0.02 & 0.00 & -0.01 & -0.01 & -0.02 & -0.04 & -0.02 & -0.03 \\
\hline & $-(0.2)$ & $(1.2)$ & $-(1.3)$ & $(0.1)$ & $-(0.7)$ & $-(0.5)$ & $-(1.2)$ & $-(3.0)$ & $-(1.3)$ & $-(1.9)$ \\
\hline \multirow[t]{2}{*}{$46-55$} & 0.00 & 0.02 & 0.03 & 0.04 & 0.03 & 0.01 & 0.01 & 0.01 & 0.00 & 0.00 \\
\hline & $-(0.1)$ & $(0.8)$ & (1.3) & $(1.9)$ & $(1.2)$ & $(0.6)$ & $(0.7)$ & (0.6) & $(0.2)$ & $-(0.1)$ \\
\hline \multirow[t]{2}{*}{$56-65$} & 0.01 & 0.02 & 0.08 & 0.06 & 0.04 & 0.04 & 0.06 & 0.07 & 0.05 & 0.07 \\
\hline & $(0.4)$ & $(0.7)$ & $(3.0)$ & $(2.4)$ & $(1.5)$ & (1.4) & (2.2) & (2.7) & (2.0) & $(2.8)$ \\
\hline \multicolumn{11}{|l|}{ Education } \\
\hline \multirow[t]{2}{*}{ Higher } & 0.01 & -0.02 & 0.02 & 0.02 & 0.03 & 0.03 & 0.02 & 0.04 & 0.00 & 0.01 \\
\hline & $(0.3)$ & $-(0.5)$ & $(0.6)$ & $(0.7)$ & $(0.9)$ & $(0.9)$ & $(0.5)$ & $(1.2)$ & $-(0.1)$ & $(0.2)$ \\
\hline \multirow[t]{2}{*}{ Higher vocational } & -0.01 & -0.05 & -0.02 & -0.02 & -0.02 & -0.01 & -0.04 & -0.02 & -0.05 & 0.00 \\
\hline & $-(0.2)$ & $-(1.7)$ & $-(0.7)$ & $-(0.8)$ & $-(0.7)$ & $-(0.4)$ & $-(1.4)$ & $-(0.6)$ & $-(1.8)$ & $(0.1)$ \\
\hline \multirow[t]{2}{*}{ Advanced high school } & 0.02 & 0.07 & 0.01 & 0.04 & 0.00 & 0.01 & 0.02 & 0.00 & 0.00 & -0.04 \\
\hline & $(0.6)$ & (1.6) & $(0.2)$ & $(1.2)$ & $(0.1)$ & $(0.2)$ & $(0.5)$ & $(0.1)$ & $-(0.1)$ & $-(1.1)$ \\
\hline \multirow[t]{2}{*}{ Apprenticeship } & -0.01 & 0.00 & -0.01 & -0.01 & 0.00 & -0.01 & 0.00 & -0.01 & 0.00 & 0.00 \\
\hline & $-(0.7)$ & $(0.5)$ & $-(0.9)$ & $-(0.6)$ & $-(0.2)$ & $-(0.9)$ & $(0.2)$ & $-(1.5)$ & $(0.5)$ & $-(0.4)$ \\
\hline \multirow[t]{2}{*}{ Mandatory or less } & 0.01 & 0.00 & 0.02 & 0.01 & 0.00 & 0.01 & 0.01 & 0.03 & 0.02 & 0.02 \\
\hline & $(0.4)$ & $(0.2)$ & (1.1) & $(0.3)$ & $(0.2)$ & $(0.7)$ & $(0.3)$ & (1.3) & $(0.9)$ & $(0.9)$ \\
\hline \multicolumn{11}{|l|}{ Gender } \\
\hline \multirow[t]{2}{*}{ Female } & 0.01 & 0.02 & 0.02 & 0.02 & 0.02 & 0.03 & 0.02 & 0.03 & 0.03 & 0.02 \\
\hline & $(0.9)$ & $(2.2)$ & $(1.6)$ & $(2.0)$ & $(2.0)$ & (2.4) & $(1.7)$ & $(3.0)$ & $(2.5)$ & $(2.3)$ \\
\hline \multirow[t]{2}{*}{ Male } & -0.01 & -0.02 & -0.01 & -0.02 & -0.02 & -0.02 & -0.01 & -0.02 & -0.02 & -0.02 \\
\hline & $-(0.9)$ & $-(2.2)$ & $-(1.6)$ & $-(2.0)$ & $-(2.0)$ & $-(2.4)$ & $-(1.7)$ & $-(3.0)$ & $-(2.5)$ & $-(2.3)$ \\
\hline \multicolumn{11}{|l|}{ Region of Residence } \\
\hline \multirow[t]{2}{*}{ German part } & 0.01 & 0.00 & 0.00 & 0.00 & 0.00 & 0.00 & 0.01 & 0.00 & 0.00 & 0.00 \\
\hline & $(1.0)$ & $(0.6)$ & $(0.3)$ & $-(0.1)$ & $(0.5)$ & $-(0.4)$ & $(0.9)$ & $-(0.7)$ & $(0.5)$ & $(0.3)$ \\
\hline \multirow[t]{2}{*}{ Latin part } & -0.01 & -0.01 & 0.00 & 0.00 & -0.01 & 0.01 & -0.01 & 0.01 & -0.01 & 0.00 \\
\hline & $-(1.0)$ & $-(0.6)$ & $-(0.3)$ & $(0.1)$ & $-(0.5)$ & $(0.4)$ & $-(0.9)$ & $(0.7)$ & $-(0.5)$ & $-(0.3)$ \\
\hline \# per & 9,883 & 11,641 & 12,715 & 18,969 & 13,863 & 13,889 & 14,022 & 14,750 & 14,592 & 15,104 \\
\hline \# observations & 14,215 & 14,528 & 14,580 & 19,834 & 13,863 & 13,889 & 14,022 & 14,750 & 14,592 & 15,104 \\
\hline
\end{tabular}

Note: Due to the rotating panel nature of the SLFS, the number of observations is not equal to the number of persons when comparing wave 1991 with waves until 1995. The t-values are based on standard errors that account for clustering.

Source: Swiss Labour Force Survey; own calculations. 
Table A4: Unemployment Regressions (Changes in Transformed Coefficients with Respect to 1991 - Corresponding t-values in Parentheses)

\begin{tabular}{|c|c|c|c|c|c|c|c|c|c|c|}
\hline Variable & 1992 & 1993 & 1994 & 1995 & 1996 & 1997 & 1998 & 1999 & 2000 & 2001 \\
\hline 1991 sample mean & $\begin{array}{l}0.18 \\
(3.9)\end{array}$ & $\begin{array}{l}0.35 \\
(7.0)\end{array}$ & $\begin{array}{l}0.36 \\
(7.1)\end{array}$ & $\begin{array}{l}0.25 \\
(5.0)\end{array}$ & $\begin{array}{l}0.35 \\
(6.8)\end{array}$ & $\begin{array}{l}0.41 \\
(8.1)\end{array}$ & $\begin{array}{l}0.37 \\
(6.8)\end{array}$ & $\begin{array}{l}0.26 \\
(4.9)\end{array}$ & $\begin{array}{l}0.21 \\
(4.0)\end{array}$ & $\begin{array}{l}0.15 \\
(2.7)\end{array}$ \\
\hline \multicolumn{11}{|l|}{ Age } \\
\hline $16-25$ & $\begin{array}{l}-0.09 \\
-(1.0)\end{array}$ & $\begin{array}{l}-0.08 \\
-(0.9)\end{array}$ & $\begin{array}{l}-0.07 \\
-(0.8)\end{array}$ & $\begin{array}{l}-0.14 \\
-(1.6)\end{array}$ & $\begin{array}{l}-0.17 \\
-(1.7)\end{array}$ & $\begin{array}{l}-0.11 \\
-(1.2)\end{array}$ & $\begin{array}{l}-0.07 \\
-(0.7)\end{array}$ & $\begin{array}{l}-0.04 \\
-(0.4)\end{array}$ & $\begin{array}{l}-0.07 \\
-(0.7)\end{array}$ & $\begin{array}{l}-0.01 \\
-(0.1)\end{array}$ \\
\hline $26-35$ & $\begin{array}{l}0.02 \\
(0.3)\end{array}$ & $\begin{array}{l}0.03 \\
(0.5)\end{array}$ & $\begin{array}{l}0.00 \\
(0.0)\end{array}$ & $\begin{array}{l}0.07 \\
(0.9)\end{array}$ & $\begin{array}{l}0.07 \\
(0.9)\end{array}$ & $\begin{array}{l}0.05 \\
(0.7)\end{array}$ & $\begin{array}{l}0.02 \\
(0.2)\end{array}$ & $\begin{array}{l}-0.07 \\
-(0.9)\end{array}$ & $\begin{array}{l}-0.02 \\
-(0.2)\end{array}$ & $\begin{array}{l}-0.09 \\
-(1.0)\end{array}$ \\
\hline $36-45$ & $\begin{array}{l}0.04 \\
(0.4)\end{array}$ & $\begin{array}{l}0.02 \\
(0.3)\end{array}$ & $\begin{array}{l}-0.07 \\
-(0.8)\end{array}$ & $\begin{array}{l}-0.05 \\
-(0.6)\end{array}$ & $\begin{array}{l}0.10 \\
(1.1)\end{array}$ & $\begin{array}{l}-0.01 \\
-(0.1)\end{array}$ & $\begin{array}{l}-0.01 \\
-(0.1)\end{array}$ & $\begin{array}{l}0.10 \\
(1.2)\end{array}$ & $\begin{array}{l}0.01 \\
(0.1)\end{array}$ & $\begin{array}{l}0.09 \\
(1.0)\end{array}$ \\
\hline $46-55$ & $\begin{array}{l}0.00 \\
(0.0)\end{array}$ & $\begin{array}{l}-0.02 \\
-(0.2)\end{array}$ & $\begin{array}{l}0.09 \\
(0.8)\end{array}$ & $\begin{array}{l}0.06 \\
(0.6)\end{array}$ & $\begin{array}{l}-0.05 \\
-(0.5)\end{array}$ & $\begin{array}{l}0.10 \\
(1.0)\end{array}$ & $\begin{array}{l}0.05 \\
(0.5)\end{array}$ & $\begin{array}{l}0.00 \\
(0.0)\end{array}$ & $\begin{array}{l}0.04 \\
(0.3)\end{array}$ & $\begin{array}{l}0.02 \\
(0.2)\end{array}$ \\
\hline $56-65$ & $\begin{array}{l}0.02 \\
(0.2)\end{array}$ & $\begin{array}{l}0.06 \\
(0.4)\end{array}$ & $\begin{array}{l}0.11 \\
(0.8)\end{array}$ & $\begin{array}{l}0.08 \\
(0.6)\end{array}$ & $\begin{array}{l}0.01 \\
(0.1)\end{array}$ & $\begin{array}{l}-0.08 \\
-(0.6)\end{array}$ & $\begin{array}{l}0.02 \\
(0.2)\end{array}$ & $\begin{array}{l}0.03 \\
(0.2)\end{array}$ & $\begin{array}{l}0.07 \\
(0.5)\end{array}$ & $\begin{array}{l}-0.02 \\
-(0.1)\end{array}$ \\
\hline Educ & & & & & & & & & & \\
\hline High & $\begin{array}{l}-0.09 \\
-(0.5)\end{array}$ & $\begin{array}{l}-0.36 \\
-(2.5)\end{array}$ & $\begin{array}{l}-0.18 \\
-(1.1)\end{array}$ & $\begin{array}{l}-0.16 \\
-(1.1)\end{array}$ & $\begin{array}{l}-0.05 \\
-(0.3)\end{array}$ & & & & $\begin{array}{l}-0.26 \\
-(1.4)\end{array}$ & $\begin{array}{l}-0.09 \\
-(0.6)\end{array}$ \\
\hline Higher vocational & $\begin{array}{l}0.16 \\
(1.3)\end{array}$ & $\begin{array}{l}0.00 \\
(0.0)\end{array}$ & $\begin{array}{l}0.08 \\
(0.5)\end{array}$ & $\begin{array}{l}-0.09 \\
-(0.6)\end{array}$ & $\begin{array}{l}-0.15 \\
-(1.0)\end{array}$ & $\begin{array}{l}0.05 \\
(0.3)\end{array}$ & $\begin{array}{l}0.09 \\
(0.5)\end{array}$ & $\begin{array}{l}-0.13 \\
-(0.7)\end{array}$ & $\begin{array}{l}-0.12 \\
-(0.8)\end{array}$ & $\begin{array}{l}-0.12 \\
-(0.8)\end{array}$ \\
\hline high school & $\begin{array}{l}0.30 \\
(2.0)\end{array}$ & $\begin{array}{l}0.19 \\
(1.2)\end{array}$ & $\begin{array}{l}0.00 \\
(0.0)\end{array}$ & & & & & & $\begin{array}{l}0.20 \\
(1.3)\end{array}$ & $\begin{array}{l}0.18 \\
(1.1)\end{array}$ \\
\hline Appr & $\begin{array}{l}-0.06 \\
-(1.5)\end{array}$ & $\begin{array}{l}0.03 \\
(0.7)\end{array}$ & $\begin{array}{l}0.00 \\
(0.0)\end{array}$ & $\begin{array}{l}-0.06 \\
-(1.4)\end{array}$ & $\begin{array}{l}-0.03 \\
-(0.7)\end{array}$ & & & & & $\begin{array}{l}-0.08 \\
-(1.7)\end{array}$ \\
\hline Mandator & $\begin{array}{l}0.00 \\
(0.0)\end{array}$ & $\begin{array}{l}-0.01 \\
-(0.1)\end{array}$ & $\begin{array}{l}0.01 \\
(0.1)\end{array}$ & $\begin{array}{l}0.19 \\
(2.2)\end{array}$ & $\begin{array}{l}0.20 \\
(2.0)\end{array}$ & $\begin{array}{l}0.17 \\
(1.9)\end{array}$ & $\begin{array}{l}0.10 \\
(1.0)\end{array}$ & $\begin{array}{l}0.18 \\
(1.9)\end{array}$ & $\begin{array}{l}0.15 \\
(1.5)\end{array}$ & $\begin{array}{l}0.25 \\
(2.6)\end{array}$ \\
\hline one & & & & & & & & & & \\
\hline Fema & $\begin{array}{l}-0.08 \\
-(1.4)\end{array}$ & $\begin{array}{l}-0.10 \\
-(1.8)\end{array}$ & $\begin{array}{l}-0.13 \\
-(2.4)\end{array}$ & $\begin{array}{l}-0.12 \\
-(2.4)\end{array}$ & $\begin{array}{l}-0.14 \\
-(2.5)\end{array}$ & $\begin{array}{l}-0.20 \\
-(3.6)\end{array}$ & $\begin{array}{l}-0.11 \\
-(1.9)\end{array}$ & $\begin{array}{l}-0.11 \\
-(1.9)\end{array}$ & $\begin{array}{l}-0.12 \\
-(2.0)\end{array}$ & $\begin{array}{l}0.01 \\
(0.1)\end{array}$ \\
\hline Male & $\begin{array}{l}0.06 \\
(1.4)\end{array}$ & $\begin{array}{l}0.07 \\
(1.8)\end{array}$ & $\begin{array}{l}0.10 \\
(2.4)\end{array}$ & $\begin{array}{l}0.09 \\
(2.4)\end{array}$ & $\begin{array}{l}0.10 \\
(2.5)\end{array}$ & $\begin{array}{l}0.15 \\
(3.6)\end{array}$ & $\begin{array}{l}0.08 \\
(1.9)\end{array}$ & $\begin{array}{l}0.08 \\
(1.9)\end{array}$ & $\begin{array}{l}0.09 \\
(2.0)\end{array}$ & $\begin{array}{l}-0.01 \\
-(0.1)\end{array}$ \\
\hline Regle & & & & & & & & & & \\
\hline Germ & $\begin{array}{l}-0.02 \\
-(0.7)\end{array}$ & $\begin{array}{l}0.00 \\
(0.2)\end{array}$ & $\begin{array}{l}-0.02 \\
-(1.0)\end{array}$ & $\begin{array}{l}-0.02 \\
-(1.1)\end{array}$ & $\begin{array}{l}-0.02 \\
-(0.8)\end{array}$ & $\begin{array}{l}0.02 \\
(0.8)\end{array}$ & $\begin{array}{l}0.01 \\
(0.2)\end{array}$ & $\begin{array}{l}0.00 \\
(0.1)\end{array}$ & $\begin{array}{l}0.01 \\
(0.4)\end{array}$ & $\begin{array}{l}0.02 \\
(0.6)\end{array}$ \\
\hline Latin part & $\begin{array}{l}0.04 \\
(0.7) \\
\end{array}$ & $\begin{array}{l}-0.01 \\
-(0.2) \\
\end{array}$ & $\begin{array}{l}0.07 \\
(1.0) \\
\end{array}$ & $\begin{array}{l}0.07 \\
(1.1) \\
\end{array}$ & $\begin{array}{l}0.06 \\
(0.8) \\
\end{array}$ & $\begin{array}{l}-0.05 \\
-(0.8) \\
\end{array}$ & $\begin{array}{l}-0.02 \\
-(0.2) \\
\end{array}$ & $\begin{array}{l}-0.01 \\
-(0.1) \\
\end{array}$ & $\begin{array}{l}-0.03 \\
-(0.4) \\
\end{array}$ & $\begin{array}{l}-0.05 \\
-(0.6) \\
\end{array}$ \\
\hline $\begin{array}{l}\text { \# persons } \\
\text { \# observat }\end{array}$ & $\begin{array}{l}14,209 \\
21,260\end{array}$ & $\begin{array}{l}17,112 \\
21,886\end{array}$ & $\begin{array}{l}18,702 \\
21,763\end{array}$ & $\begin{array}{l}28,849 \\
30,291\end{array}$ & $\begin{array}{l}20,587 \\
20,587\end{array}$ & $\begin{array}{l}20,659 \\
20,659\end{array}$ & $\begin{array}{l}20,836 \\
20,836\end{array}$ & $\begin{array}{l}21,682 \\
21,682\end{array}$ & $\begin{array}{l}21,590 \\
21,590\end{array}$ & $\begin{array}{l}22,141 \\
22,141\end{array}$ \\
\hline
\end{tabular}

Note: Due to the rotating panel nature of the SLFS, the number of observations is not equal to the number of persons when comparing wave 1991 with waves until 1995. The t-values are based on standard errors that account for clustering.

Source: Swiss Labor Force Survey; own calculations. 
Table A5: Degree of Unemployment Regressions (Changes in Transformed Coefficients with Respect to 1991 - Corresponding t-values in Parentheses)

\begin{tabular}{|c|c|c|c|c|c|c|c|c|c|c|}
\hline Variable & 1992 & 1993 & 1994 & 1995 & 1996 & 1997 & 1998 & 1999 & 2000 & 2001 \\
\hline 1991 sample mean & $\begin{array}{l}0.69 \\
(3.7)\end{array}$ & $\begin{array}{l}1.69 \\
(7.4)\end{array}$ & $\begin{array}{l}2.03 \\
(8.4)\end{array}$ & $\begin{array}{l}1.32 \\
(6.8)\end{array}$ & $\begin{array}{l}2.11 \\
(7.4)\end{array}$ & $\begin{array}{l}2.40 \\
(8.9)\end{array}$ & $\begin{array}{l}2.13 \\
(7.4)\end{array}$ & $\begin{array}{l}1.49 \\
(6.0)\end{array}$ & $\begin{array}{l}0.90 \\
(4.0)\end{array}$ & $\begin{array}{l}0.75 \\
(3.1)\end{array}$ \\
\hline \multicolumn{11}{|l|}{ Age } \\
\hline $16-25$ & $\begin{array}{l}-0.18 \\
-(0.3)\end{array}$ & $\begin{array}{l}0.42 \\
(0.6)\end{array}$ & $\begin{array}{l}0.38 \\
(0.6)\end{array}$ & $\begin{array}{l}-0.29 \\
-(0.6)\end{array}$ & $\begin{array}{l}-0.33 \\
-(0.4)\end{array}$ & $\begin{array}{c}0.02 \\
(0.0)\end{array}$ & $\begin{array}{l}0.41 \\
(0.5)\end{array}$ & $\begin{array}{c}0.43 \\
(0.6)\end{array}$ & $\begin{array}{l}-0.25 \\
-(0.4)\end{array}$ & $\begin{array}{c}0.48 \\
(0.6)\end{array}$ \\
\hline $26-35$ & $\begin{array}{l}0.44 \\
(1.3)\end{array}$ & $\begin{array}{l}0.41 \\
(1.1)\end{array}$ & $\begin{array}{l}0.15 \\
(0.4)\end{array}$ & $\begin{array}{l}0.49 \\
(1.4)\end{array}$ & $\begin{array}{l}1.06 \\
(1.9)\end{array}$ & $\begin{array}{l}0.79 \\
(1.7)\end{array}$ & $\begin{array}{l}0.65 \\
(1.4)\end{array}$ & $\begin{array}{l}-0.22 \\
-(0.6)\end{array}$ & $\begin{array}{l}0.26 \\
(0.7)\end{array}$ & $\begin{array}{l}-0.38 \\
-(1.1)\end{array}$ \\
\hline $36-45$ & $\begin{array}{l}-0.08 \\
-(0.3)\end{array}$ & $\begin{array}{l}-0.41 \\
-(1.1)\end{array}$ & $\begin{array}{l}-0.81 \\
-(2.1)\end{array}$ & $\begin{array}{l}-0.40 \\
-(1.3)\end{array}$ & $\begin{array}{l}-0.09 \\
-(0.2)\end{array}$ & $\begin{array}{l}-0.49 \\
-(1.1)\end{array}$ & $\begin{array}{l}-0.85 \\
-(1.8)\end{array}$ & $\begin{array}{l}0.05 \\
(0.1)\end{array}$ & $\begin{array}{l}-0.22 \\
-(0.6)\end{array}$ & $\begin{array}{l}-0.03 \\
-(0.1)\end{array}$ \\
\hline $46-55$ & $\begin{array}{l}-0.24 \\
-(0.8)\end{array}$ & $\begin{array}{l}-0.44 \\
-(1.2)\end{array}$ & $\begin{array}{l}0.15 \\
(0.4)\end{array}$ & $\begin{array}{l}0.00 \\
(0.0)\end{array}$ & $\begin{array}{l}-0.63 \\
-(1.5)\end{array}$ & $\begin{array}{l}0.16 \\
(0.3)\end{array}$ & $\begin{array}{l}-0.24 \\
-(0.6)\end{array}$ & $\begin{array}{l}-0.23 \\
-(0.6)\end{array}$ & $\begin{array}{l}0.01 \\
(0.0)\end{array}$ & $\begin{array}{l}0.06 \\
(0.2)\end{array}$ \\
\hline $56-65$ & $\begin{array}{l}-0.11 \\
-(0.3)\end{array}$ & $\begin{array}{l}-0.04 \\
-(0.1)\end{array}$ & $\begin{array}{l}0.40 \\
(0.6)\end{array}$ & $\begin{array}{l}0.23 \\
(0.4)\end{array}$ & $\begin{array}{l}-0.58 \\
-(1.0)\end{array}$ & $\begin{array}{l}-1.13 \\
-(1.8)\end{array}$ & $\begin{array}{c}-0.02 \\
(0.0)\end{array}$ & $\begin{array}{l}0.06 \\
(0.1)\end{array}$ & $\begin{array}{l}0.27 \\
(0.5)\end{array}$ & $\begin{array}{c}-0.01 \\
(0.0)\end{array}$ \\
\hline Education & & & & & & & & & & \\
\hline Higher & $\begin{array}{l}-0.22 \\
-(0.3)\end{array}$ & $\begin{array}{l}-1.50 \\
-(2.3)\end{array}$ & $\begin{array}{l}-0.21 \\
-(0.2)\end{array}$ & $\begin{array}{l}-0.97 \\
-(1.5)\end{array}$ & $\begin{array}{l}0.62 \\
(0.5)\end{array}$ & $\begin{array}{l}0.68 \\
(0.6)\end{array}$ & $\begin{array}{l}-0.25 \\
-(0.2)\end{array}$ & $\begin{array}{l}-0.52 \\
-(0.6)\end{array}$ & $\begin{array}{l}-1.18 \\
-(1.6)\end{array}$ & $\begin{array}{l}-0.37 \\
-(0.5)\end{array}$ \\
\hline Higher vocational & $\begin{array}{l}0.41 \\
(0.9)\end{array}$ & $\begin{array}{l}-0.58 \\
-(1.3)\end{array}$ & $\begin{array}{l}-0.69 \\
-(1.3)\end{array}$ & $\begin{array}{l}-0.93 \\
-(2.4)\end{array}$ & $\begin{array}{l}-1.40 \\
-(2.9)\end{array}$ & $\begin{array}{l}-0.67 \\
-(1.0)\end{array}$ & $\begin{array}{l}-0.33 \\
-(0.5)\end{array}$ & $\begin{array}{l}-1.02 \\
-(2.0)\end{array}$ & $\begin{array}{l}-0.92 \\
-(2.4)\end{array}$ & $\begin{array}{l}-0.63 \\
-(1.7)\end{array}$ \\
\hline Advan & $\begin{array}{l}1.89 \\
(2.1)\end{array}$ & $\begin{array}{l}0.19 \\
(0.2)\end{array}$ & $\begin{array}{l}-0.29 \\
-(0.4)\end{array}$ & $\begin{array}{l}1.57 \\
(1.9)\end{array}$ & $\begin{array}{l}-1.20 \\
-(1.7)\end{array}$ & $\begin{array}{l}-0.86 \\
-(1.1)\end{array}$ & $\begin{array}{l}-0.56 \\
-(0.6)\end{array}$ & $\begin{array}{l}-0.78 \\
-(1.2)\end{array}$ & $\begin{array}{l}0.80 \\
(1.2)\end{array}$ & $\begin{array}{l}0.63 \\
(0.8)\end{array}$ \\
\hline Appre & $\begin{array}{l}-0.26 \\
-(1.4)\end{array}$ & $\begin{array}{l}0.29 \\
(1.4)\end{array}$ & $\begin{array}{l}0.08 \\
(0.4)\end{array}$ & $\begin{array}{l}-0.34 \\
-(1.8)\end{array}$ & $\begin{array}{l}-0.47 \\
-(1.8)\end{array}$ & $\begin{array}{l}-0.64 \\
-(2.5)\end{array}$ & $\begin{array}{l}-0.21 \\
-(0.8)\end{array}$ & $\begin{array}{l}-0.25 \\
-(1.1)\end{array}$ & $\begin{array}{l}-0.24 \\
-(1.1)\end{array}$ & $\begin{array}{l}-0.51 \\
-(2.4)\end{array}$ \\
\hline Manc & $\begin{array}{l}-0.06 \\
-(0.1)\end{array}$ & $\begin{array}{l}0.04 \\
(0.1)\end{array}$ & $\begin{array}{l}0.36 \\
(0.7)\end{array}$ & $\begin{array}{l}1.29 \\
(2.6)\end{array}$ & $\begin{array}{l}2.21 \\
(2.7)\end{array}$ & $\begin{array}{l}2.09 \\
(3.1)\end{array}$ & $\begin{array}{l}0.98 \\
(1.5)\end{array}$ & $\begin{array}{l}1.65 \\
(2.8)\end{array}$ & $\begin{array}{l}1.32 \\
(2.1)\end{array}$ & $\begin{array}{l}1.63 \\
(2.6)\end{array}$ \\
\hline с & & & & & & & & & & \\
\hline Female & $\begin{array}{l}-0.18 \\
-(0.8)\end{array}$ & $\begin{array}{l}-0.33 \\
-(1.3)\end{array}$ & $\begin{array}{l}-0.53 \\
-(1.9)\end{array}$ & $\begin{array}{l}-0.31 \\
-(1.3)\end{array}$ & $\begin{array}{l}-0.47 \\
-(1.4)\end{array}$ & $\begin{array}{l}-0.92 \\
-(3.0)\end{array}$ & $\begin{array}{l}-0.06 \\
-(0.2)\end{array}$ & $\begin{array}{l}-0.22 \\
-(0.8)\end{array}$ & $\begin{array}{l}-0.45 \\
-(1.8)\end{array}$ & $\begin{array}{l}0.17 \\
(0.6)\end{array}$ \\
\hline Male & $\begin{array}{c}0.13 \\
(0.8)\end{array}$ & $\begin{array}{l}0.25 \\
(1.3)\end{array}$ & $\begin{array}{l}0.39 \\
(1.9)\end{array}$ & $\begin{array}{l}0.23 \\
(1.3)\end{array}$ & $\begin{array}{l}0.35 \\
(1.4)\end{array}$ & $\begin{array}{l}0.69 \\
(3.0)\end{array}$ & $\begin{array}{l}0.04 \\
(0.2)\end{array}$ & $\begin{array}{l}0.16 \\
(0.8)\end{array}$ & $\begin{array}{l}0.33 \\
(1.8)\end{array}$ & $\begin{array}{l}-0.13 \\
-(0.6)\end{array}$ \\
\hline Regic & & & & & & & & & & \\
\hline Germa & $\begin{array}{l}-0.24 \\
-(2.0)\end{array}$ & $\begin{array}{l}-0.27 \\
-(1.9)\end{array}$ & $\begin{array}{l}-0.57 \\
-(3.6)\end{array}$ & $\begin{array}{l}-0.54 \\
-(4.4)\end{array}$ & $\begin{array}{l}-0.64 \\
-(3.1)\end{array}$ & $\begin{array}{l}-0.30 \\
-(1.6)\end{array}$ & $\begin{array}{l}-0.31 \\
-(1.6)\end{array}$ & $\begin{array}{l}-0.19 \\
-(1.2)\end{array}$ & $\begin{array}{l}-0.02 \\
-(0.2)\end{array}$ & $\begin{array}{l}-0.05 \\
-(0.3)\end{array}$ \\
\hline Latin part & $\begin{array}{l}0.69 \\
(2.0)\end{array}$ & $\begin{array}{l}0.77 \\
(1.9)\end{array}$ & $\begin{array}{l}1.63 \\
(3.6)\end{array}$ & $\begin{array}{l}1.55 \\
(4.4)\end{array}$ & $\begin{array}{l}1.84 \\
(3.1)\end{array}$ & $\begin{array}{l}0.86 \\
(1.6)\end{array}$ & $\begin{array}{r}0.90 \\
(1.6)\end{array}$ & $\begin{array}{l}0.55 \\
(1.2)\end{array}$ & $\begin{array}{l}0.07 \\
(0.2)\end{array}$ & $\begin{array}{c}0.13 \\
(0.3)\end{array}$ \\
\hline & 14,200 & 17,101 & 8,685 & 28,829 & 20,566 & 20,641 & 20,821 & 21,666 & 21,572 & 22,126 \\
\hline \# observations & 21,238 & 21,870 & 21,743 & 30,268 & 20,566 & 20,641 & 20,821 & 21,666 & 21,572 & 22,126 \\
\hline
\end{tabular}

Note: Due to the rotating panel nature of the SLFS, the number of observations is not equal to the number of persons when comparing wave 1991 with waves until 1995. The t-values are based on standard errors that account for clustering.

Source: Swiss Labor Force Survey; own calculations. 
Table A6: Non-Employment Regressions (Changes in Transformed Coefficients with Respect to 1991 - Corresponding t-values in Parentheses)

\begin{tabular}{|c|c|c|c|c|c|c|c|c|c|c|}
\hline Variable & 1992 & 1993 & 1994 & 1995 & 1996 & 1997 & 1998 & 1999 & 2000 & 2001 \\
\hline 1991 sample mean & $\begin{array}{l}0.01 \\
(0.8)\end{array}$ & $\begin{array}{l}0.07 \\
(3.5)\end{array}$ & $\begin{array}{c}0.11 \\
(5.1)\end{array}$ & $\begin{array}{l}0.08 \\
(3.9)\end{array}$ & $\begin{array}{l}0.10 \\
(4.3)\end{array}$ & $\begin{array}{c}0.13 \\
(5.5)\end{array}$ & $\begin{array}{l}0.08 \\
(3.2)\end{array}$ & $\begin{array}{l}0.05 \\
(2.1)\end{array}$ & $\begin{array}{l}0.05 \\
(2.0)\end{array}$ & $\begin{array}{c}0.03 \\
(1.5)\end{array}$ \\
\hline \multicolumn{11}{|l|}{ Age } \\
\hline $16-25$ & $\begin{array}{l}0.00 \\
(0.1)\end{array}$ & $\begin{array}{l}-0.03 \\
-(0.6)\end{array}$ & $\begin{array}{l}0.07 \\
(1.5)\end{array}$ & $\begin{array}{l}0.07 \\
(1.7)\end{array}$ & $\begin{array}{l}0.03 \\
(0.7)\end{array}$ & $\begin{array}{l}0.03 \\
(0.7)\end{array}$ & $\begin{array}{l}0.06 \\
(1.2)\end{array}$ & $\begin{array}{l}0.06 \\
(1.1)\end{array}$ & $\begin{array}{l}0.03 \\
(0.6)\end{array}$ & $\begin{array}{l}0.07 \\
(1.3)\end{array}$ \\
\hline $26-35$ & $\begin{array}{l}0.05 \\
(1.8)\end{array}$ & $\begin{array}{l}0.09 \\
(2.5)\end{array}$ & $\begin{array}{l}0.06 \\
(1.6)\end{array}$ & $\begin{array}{l}-0.01 \\
-(0.2)\end{array}$ & $\begin{array}{l}0.01 \\
(0.3)\end{array}$ & $\begin{array}{l}-0.06 \\
-(1.4)\end{array}$ & $\begin{array}{l}-0.06 \\
-(1.5)\end{array}$ & $\begin{array}{l}-0.11 \\
-(2.7)\end{array}$ & $\begin{array}{l}-0.06 \\
-(1.6)\end{array}$ & $\begin{array}{l}-0.01 \\
-(0.3)\end{array}$ \\
\hline $36-45$ & $\begin{array}{l}0.02 \\
(0.5)\end{array}$ & $\begin{array}{l}0.03 \\
(0.7)\end{array}$ & $\begin{array}{c}0.04 \\
-(1.0)\end{array}$ & $\begin{array}{l}0.00 \\
(0.1)\end{array}$ & $\begin{array}{l}0.04 \\
(1.0)\end{array}$ & $\begin{array}{l}0.08 \\
(1.8)\end{array}$ & $\begin{array}{l}0.03 \\
(0.7)\end{array}$ & $\begin{array}{l}0.08 \\
(1.9)\end{array}$ & $\begin{array}{l}0.02 \\
(0.4)\end{array}$ & $\begin{array}{l}0.00 \\
(0.0)\end{array}$ \\
\hline $46-55$ & $\begin{array}{l}-0.06 \\
-(1.7)\end{array}$ & $\begin{array}{l}-0.05 \\
-(1.2)\end{array}$ & $\begin{array}{c}0.03 \\
-(0.7)\end{array}$ & $\begin{array}{l}-0.04 \\
-(0.8)\end{array}$ & $\begin{array}{l}-0.06 \\
-(1.2)\end{array}$ & $\begin{array}{l}-0.01 \\
-(0.2)\end{array}$ & $\begin{array}{l}0.02 \\
(0.5)\end{array}$ & $\begin{array}{l}0.00 \\
(0.0)\end{array}$ & $\begin{array}{l}0.03 \\
(0.7)\end{array}$ & $\begin{array}{l}0.00 \\
(0.0)\end{array}$ \\
\hline $56-65$ & $\begin{array}{l}-0.04 \\
-(1.0)\end{array}$ & $\begin{array}{l}-0.08 \\
-(1.8)\end{array}$ & $\begin{array}{c}0.09 \\
-(2.1)\end{array}$ & $\begin{array}{l}-0.05 \\
-(1.1)\end{array}$ & $\begin{array}{l}-0.06 \\
-(1.2)\end{array}$ & $\begin{array}{l}-0.06 \\
-(1.3)\end{array}$ & $\begin{array}{l}-0.05 \\
-(1.1)\end{array}$ & $\begin{array}{l}-0.01 \\
-(0.3)\end{array}$ & $\begin{array}{l}0.00 \\
(0.1)\end{array}$ & $\begin{array}{l}-0.07 \\
-(1.6)\end{array}$ \\
\hline Education & & & & & & & & & & \\
\hline Higher & $\begin{array}{l}-0.05 \\
-(0.7)\end{array}$ & $\begin{array}{l}0.01 \\
(0.1)\end{array}$ & $\begin{array}{l}0.11 \\
(1.2)\end{array}$ & $\begin{array}{l}-0.08 \\
-(1.0)\end{array}$ & $\begin{array}{l}0.04 \\
(0.4)\end{array}$ & $\begin{array}{l}0.02 \\
(0.2)\end{array}$ & $\begin{array}{l}-0.08 \\
-(0.8)\end{array}$ & $\begin{array}{l}-0.03 \\
-(0.3)\end{array}$ & $\begin{array}{l}-0.07 \\
-(0.7)\end{array}$ & $\begin{array}{l}-0.11 \\
-(1.2)\end{array}$ \\
\hline Higher vocational & $\begin{array}{l}0.00 \\
(0.0)\end{array}$ & $\begin{array}{l}-0.05 \\
-(0.8)\end{array}$ & $\begin{array}{c}0.01 \\
-(0.1)\end{array}$ & $\begin{array}{l}-0.01 \\
-(0.2)\end{array}$ & $\begin{array}{l}-0.17 \\
-(2.2)\end{array}$ & $\begin{array}{l}-0.13 \\
-(1.7)\end{array}$ & $\begin{array}{l}-0.09 \\
-(1.1)\end{array}$ & $\begin{array}{l}-0.20 \\
-(2.7)\end{array}$ & $\begin{array}{l}-0.13 \\
-(1.9)\end{array}$ & $\begin{array}{l}-0.13 \\
-(1.9)\end{array}$ \\
\hline Advanc & $\begin{array}{l}0.03 \\
(0.4)\end{array}$ & $\begin{array}{l}-0.02 \\
-(0.3)\end{array}$ & $\begin{array}{c}0.15 \\
-(2.0)\end{array}$ & $\begin{array}{l}-0.07 \\
-(1.1)\end{array}$ & $\begin{array}{l}-0.07 \\
-(0.8)\end{array}$ & $\begin{array}{l}-0.08 \\
-(1.0)\end{array}$ & $\begin{array}{l}-0.12 \\
-(1.6)\end{array}$ & $\begin{array}{l}-0.08 \\
-(1.1)\end{array}$ & $\begin{array}{l}-0.14 \\
-(1.9)\end{array}$ & $\begin{array}{l}-0.13 \\
-(1.7)\end{array}$ \\
\hline Apprenticeship & $\begin{array}{l}-0.01 \\
-(0.7)\end{array}$ & $\begin{array}{l}0.02 \\
(0.9)\end{array}$ & $\begin{array}{l}0.01 \\
(0.4)\end{array}$ & $\begin{array}{l}0.01 \\
(0.3)\end{array}$ & $\begin{array}{l}0.02 \\
(0.8)\end{array}$ & $\begin{array}{l}0.01 \\
(0.4)\end{array}$ & $\begin{array}{l}0.02 \\
(0.7)\end{array}$ & $\begin{array}{l}0.02 \\
(0.9)\end{array}$ & $\begin{array}{l}-0.01 \\
-(0.5)\end{array}$ & $\begin{array}{l}0.01 \\
(0.5)\end{array}$ \\
\hline Mand & $\begin{array}{l}0.03 \\
(1.0)\end{array}$ & $\begin{array}{l}-0.01 \\
-(0.4)\end{array}$ & $\begin{array}{c}0.00 \\
-(0.1)\end{array}$ & $\begin{array}{l}0.04 \\
(1.0)\end{array}$ & $\begin{array}{l}0.05 \\
(1.2)\end{array}$ & $\begin{array}{l}0.06 \\
(1.4)\end{array}$ & $\begin{array}{l}0.06 \\
(1.6)\end{array}$ & $\begin{array}{l}0.08 \\
(2.0)\end{array}$ & $\begin{array}{l}0.14 \\
(3.5)\end{array}$ & $\begin{array}{l}0.10 \\
(2.5)\end{array}$ \\
\hline crou & & & & & & & & & & \\
\hline Female & $\begin{array}{l}-0.04 \\
-(1.9)\end{array}$ & $\begin{array}{l}-0.07 \\
-(3.3)\end{array}$ & $\begin{array}{c}0.08 \\
-(3.7)\end{array}$ & $\begin{array}{l}-0.06 \\
-(3.0)\end{array}$ & $\begin{array}{l}-0.11 \\
-(4.5)\end{array}$ & $\begin{array}{l}-0.15 \\
-(6.1)\end{array}$ & $\begin{array}{l}-0.12 \\
-(5.2)\end{array}$ & $\begin{array}{l}-0.12 \\
-(5.3)\end{array}$ & $\begin{array}{l}-0.11 \\
-(4.8)\end{array}$ & $\begin{array}{l}-0.12 \\
-(5.2)\end{array}$ \\
\hline Male & $\begin{array}{c}0.04 \\
(1.9)\end{array}$ & $\begin{array}{l}0.07 \\
(3.3)\end{array}$ & $\begin{array}{l}0.08 \\
(3.7)\end{array}$ & $\begin{array}{l}0.06 \\
(3.0)\end{array}$ & $\begin{array}{l}0.11 \\
(4.5)\end{array}$ & $\begin{array}{l}0.15 \\
(6.1)\end{array}$ & $\begin{array}{l}0.12 \\
(5.2)\end{array}$ & $\begin{array}{l}0.12 \\
(5.3)\end{array}$ & $\begin{array}{l}0.11 \\
(4.8)\end{array}$ & $\begin{array}{l}0.13 \\
(5.2)\end{array}$ \\
\hline$N e g t 0$ & & & & & & & & & & \\
\hline Germa & $\begin{array}{l}0.01 \\
(1.0)\end{array}$ & $\begin{array}{l}0.01 \\
(0.5)\end{array}$ & $\begin{array}{c}0.00 \\
-(0.2)\end{array}$ & $\begin{array}{c}0.00 \\
-(0.1)\end{array}$ & $\begin{array}{c}0.00 \\
-(0.3)\end{array}$ & $\begin{array}{l}0.00 \\
(0.3)\end{array}$ & $\begin{array}{l}-0.01 \\
-(1.0)\end{array}$ & $\begin{array}{c}0.00 \\
-(0.3)\end{array}$ & $\begin{array}{l}0.00 \\
(0.0)\end{array}$ & $\begin{array}{l}0.02 \\
(1.8)\end{array}$ \\
\hline Latin part & $\begin{array}{l}-0.02 \\
-(1.0)\end{array}$ & $\begin{array}{l}-0.01 \\
-(0.5)\end{array}$ & $\begin{array}{l}0.01 \\
(0.2)\end{array}$ & $\begin{array}{c}0.00 \\
(0.1)\end{array}$ & $\begin{array}{l}0.01 \\
(0.3)\end{array}$ & $\begin{array}{l}-0.01 \\
-(0.3)\end{array}$ & $\begin{array}{c}0.03 \\
(1.0)\end{array}$ & $\begin{array}{c}0.01 \\
(0.3)\end{array}$ & $\begin{array}{l}0.00 \\
(0.0)\end{array}$ & $\begin{array}{l}-0.06 \\
-(1.8)\end{array}$ \\
\hline & 17,208 & 20,884 & 23,070 & 35,975 & 25,700 & 25,774 & 25,860 & 26,839 & 26,800 & 27,393 \\
\hline \# observations & 26,447 & 27,289 & 27,216 & 37,966 & 25,700 & 25,774 & 25,860 & 26,839 & 26,800 & 27,393 \\
\hline
\end{tabular}

Note: Due to the rotating panel nature of the SLFS, the number of observations is not equal to the number of persons when comparing wave 1991 with waves until 1995. The t-values are based on standard errors that account for clustering.

Source: Swiss Labor Force Survey; own calculations. 


\section{Appendix B}

Table B1: Sample Sizes

\begin{tabular}{|c|c|c|c|c|c|c|c|}
\hline \multirow[t]{2}{*}{ Year } & \multirow{2}{*}{$\begin{array}{l}\text { Number of } \\
\text { Observations } \\
\text { in Wave }\end{array}$} & \multirow{2}{*}{$\begin{array}{c}\text { Age Between } \\
16 \text { and } 65 \\
\text { Years }\end{array}$} & \multicolumn{3}{|c|}{ Wage Model Sample } & \multicolumn{2}{|c|}{ Unemployment Model Sample } \\
\hline & & & $\begin{array}{c}\text { Number of } \\
\text { Employed } \\
\text { People }\end{array}$ & $\begin{array}{c}\text { Number of } \\
\text { People with } \\
\text { Reported } \\
\text { Hourly Wage }\end{array}$ & $\begin{array}{c}\text { No } \\
\text { Apprentices, } \\
\text { Self- } \\
\text { Employed, } \\
\text { or Other } \\
\text { Missings } \\
\end{array}$ & $\begin{array}{l}\text { Number of } \\
\text { People in the } \\
\text { Labour Force }\end{array}$ & $\begin{array}{l}\text { No Other } \\
\text { Missings }\end{array}$ \\
\hline 1991 & 16,016 & 13,075 & 10,210 & 7,645 & 6,791 & 10,400 & 10,312 \\
\hline 1992 & 16,921 & 13,710 & 10,724 & 8,508 & 7,424 & 11,040 & 10,948 \\
\hline 1993 & 18,103 & 14,546 & 11,236 & 8,890 & 7,737 & 11,659 & 11,574 \\
\hline 1994 & 17,911 & 14,471 & 11,098 & 8,893 & 7,789 & 11,538 & 11,451 \\
\hline 1995 & 31,827 & 25,320 & 19,490 & 15,055 & 13,043 & 20,111 & 19,979 \\
\hline 1996 & 16,235 & 12,815 & 9,952 & 8,364 & 7,072 & 10,290 & 10,275 \\
\hline 1997 & 16,207 & 12,911 & 10,015 & 8,414 & 7,098 & 10,376 & 10,347 \\
\hline 1998 & 16,326 & 13,007 & 10,252 & 8,572 & 7,231 & 10,566 & 10,524 \\
\hline 1999 & 17,738 & 13,983 & 11,107 & 9,503 & 7,959 & 11,411 & 11,370 \\
\hline 2000 & 17,748 & 13,941 & 11,081 & 9,399 & 7,801 & 11,315 & 11,278 \\
\hline 2001 & 18,751 & 14,536 & 11,641 & 9,979 & 8,313 & 11,871 & 11,829 \\
\hline
\end{tabular}

Note: In 1995, the sample size of the SLFS was roughly doubled.

Source: Swiss Labour Force Survey; own calculations.

Table B2: Weighted Sample Means for SLFS Wage Regressions (Percent for Dummy Variables)

\begin{tabular}{|c|c|c|c|c|c|c|c|c|c|c|c|}
\hline Variable & 1991 & 1992 & 1993 & 1994 & 1995 & 1996 & 1997 & 1998 & 1999 & 2000 & 2001 \\
\hline log hourly wage & 3.45 & 3.49 & 3.49 & 3.50 & 3.50 & 3.47 & 3.46 & 3.47 & 3.49 & 3.49 & 3.51 \\
\hline \multicolumn{12}{|l|}{ Age } \\
\hline $16-25$ & 18 & 17 & 16 & 14 & 13 & 13 & 14 & 13 & 12 & 13 & 12 \\
\hline $26-35$ & 28 & 29 & 29 & 29 & 30 & 30 & 30 & 30 & 30 & 27 & 26 \\
\hline $36-45$ & 24 & 24 & 25 & 26 & 26 & 26 & 25 & 26 & 27 & 29 & 29 \\
\hline $46-55$ & 20 & 20 & 21 & 21 & 21 & 22 & 21 & 21 & 21 & 21 & 21 \\
\hline $56-65$ & 10 & 11 & 10 & 10 & 10 & 10 & 9 & 10 & 10 & 10 & 11 \\
\hline \multicolumn{12}{|l|}{ Education } \\
\hline Higher & 7 & 8 & 8 & 8 & 9 & 9 & 9 & 10 & 10 & 10 & 10 \\
\hline Higher vocational & 12 & 12 & 13 & 13 & 12 & 13 & 13 & 13 & 13 & 14 & 15 \\
\hline Advanced high school & 7 & 7 & 7 & 7 & 6 & 7 & 8 & 8 & 8 & 8 & 9 \\
\hline Apprenticeship & 56 & 57 & 55 & 56 & 56 & 57 & 56 & 55 & 54 & 53 & 52 \\
\hline Mandat. school or less & 18 & 17 & 17 & 16 & 16 & 14 & 15 & 14 & 15 & 14 & 14 \\
\hline \multicolumn{12}{|l|}{ Gender } \\
\hline Female & 42 & 42 & 42 & 43 & 43 & 44 & 45 & 45 & 45 & 46 & 46 \\
\hline Male & 58 & 58 & 58 & 57 & 57 & 56 & 55 & 55 & 55 & 54 & 54 \\
\hline \multicolumn{12}{|l|}{ Region } \\
\hline German part & 75 & 73 & 74 & 74 & 73 & 74 & 75 & 75 & 73 & 74 & 73 \\
\hline Latin part & 25 & 27 & 26 & 26 & 27 & 26 & 25 & 25 & 27 & 26 & 27 \\
\hline \# observations & 6,791 & 7,424 & 7,737 & 7,789 & 13,043 & 7,072 & 7,098 & 7,231 & 7,959 & 7,801 & 8,313 \\
\hline
\end{tabular}

Source: Swiss Labour Force Survey (SLFS); own calculations. 
Table B3: Weighted Sample Means for WSS Wage Regressions (Percent for Dummy Variables)

\begin{tabular}{lcccc}
\hline \hline Variable & $\mathbf{1 9 9 4}$ & $\mathbf{1 9 9 6}$ & $\mathbf{1 9 9 8}$ & $\mathbf{2 0 0 0}$ \\
\hline log hourly wage & 8.54 & 8.55 & 8.57 & 8.58 \\
Age & & & & \\
$16-25$ & 15 & 12 & 12 & 12 \\
$26-35$ & 31 & 31 & 30 & 29 \\
$36-45$ & 24 & 26 & 27 & 28 \\
$46-55$ & 20 & 21 & 21 & 21 \\
56-65 & 9 & 9 & 10 & 10 \\
Education & & & & \\
Higher & 4 & 4 & 5 & 5 \\
Higher vocational & 11 & 12 & 13 & 12 \\
Advanced high school & 2 & 2 & 2 & 2 \\
Apprenticeship & 51 & 52 & 54 & 53 \\
Mandat. school or less & 30 & 26 & 23 & 23 \\
Other & 2 & 3 & 4 & 5 \\
Gender & & & & \\
Female & 62 & 60 & 62 & 61 \\
Male & 38 & 40 & 38 & 39 \\
Region & & & & \\
German part & 72 & 73 & 73 & 75 \\
Latin part & 28 & 27 & 27 & 25 \\
\hline \# observations & 376,289 & 378,004 & 357,803 & 437,505 \\
\hline \hline
\end{tabular}

Source: Swiss Wage Structure Survey (WSS) (BFS, Lohnstrukturerhebung); own calculations.

Table B4: Weighted Sample Means for Non-Employment Regressions (Percent)

\begin{tabular}{|c|c|c|c|c|c|c|c|c|c|c|c|}
\hline Variable & 1991 & 1992 & 1993 & 1994 & 1995 & 1996 & 1997 & 1998 & 1999 & 2000 & 2001 \\
\hline Unemployed & 21.3 & 21.1 & 22.0 & 23.0 & 22.3 & 22.5 & 23.0 & 21.7 & 21.3 & 21.3 & 20.5 \\
\hline \multicolumn{12}{|l|}{ Age } \\
\hline $16-25$ & 20 & 20 & 19 & 19 & 18 & 18 & 18 & 18 & 17 & 17 & 17 \\
\hline $26-35$ & 24 & 25 & 24 & 25 & 25 & 25 & 24 & 24 & 23 & 22 & 21 \\
\hline $36-45$ & 21 & 22 & 22 & 23 & 23 & 23 & 23 & 23 & 24 & 25 & 26 \\
\hline $46-55$ & 19 & 18 & 20 & 20 & 20 & 20 & 20 & 20 & 20 & 20 & 20 \\
\hline $56-65$ & 15 & 15 & 15 & 15 & 15 & 15 & 15 & 15 & 15 & 16 & 16 \\
\hline \multicolumn{12}{|l|}{ Education } \\
\hline Higher & 6 & 7 & 7 & 7 & 8 & 8 & 8 & 8 & 9 & 9 & 9 \\
\hline Higher vocational & 11 & 11 & 11 & 11 & 11 & 11 & 11 & 11 & 12 & 12 & 12 \\
\hline Advanced high school & 7 & 7 & 7 & 7 & 6 & 7 & 8 & 8 & 8 & 8 & 9 \\
\hline Apprenticeship & 52 & 52 & 51 & 51 & 52 & 52 & 52 & 51 & 50 & 49 & 49 \\
\hline Mandat. school or less & 24 & 23 & 24 & 24 & 24 & 22 & 22 & 22 & 22 & 22 & 20 \\
\hline \multicolumn{12}{|l|}{ Gender } \\
\hline Female & 50 & 50 & 50 & 50 & 50 & 50 & 50 & 50 & 50 & 50 & 50 \\
\hline Male & 50 & 50 & 50 & 50 & 50 & 50 & 50 & 50 & 50 & 50 & 50 \\
\hline \multicolumn{12}{|l|}{ Region of Residence } \\
\hline German part & 73 & 72 & 72 & 73 & 72 & 72 & 72 & 72 & 72 & 72 & 73 \\
\hline Latin part & 27 & 28 & 28 & 27 & 28 & 28 & 28 & 28 & 28 & 28 & 27 \\
\hline \# observations & 12,910 & 13,537 & 14,379 & 14,306 & 25,056 & 12,790 & 12,864 & 12,950 & 13,929 & 13,890 & 14,483 \\
\hline
\end{tabular}

Source: Swiss Labour Force Survey; own calculations. 
Table B5: Weighted Sample Unemployment Rates by Subgroup (Percent)

\begin{tabular}{|c|c|c|c|c|c|c|c|c|c|c|c|}
\hline Variable & 1991 & 1992 & 1993 & 1994 & 1995 & 1996 & 1997 & 1998 & 1999 & 2000 & 2001 \\
\hline Total sample & 1.7 & 2.5 & 3.5 & 3.6 & 3.0 & 3.7 & 4.1 & 3.6 & 3.0 & 2.6 & 2.5 \\
\hline \multicolumn{12}{|l|}{ Age } \\
\hline $16-25$ & 3.1 & 3.7 & 5.4 & 5.7 & 4.4 & 5.1 & 5.9 & 5.7 & 5.7 & 4.6 & 5.3 \\
\hline $26-35$ & 1.7 & 2.7 & 3.9 & 3.7 & 3.5 & 4.4 & 4.7 & 3.8 & 2.5 & 2.4 & 1.9 \\
\hline $36-45$ & 1.3 & 2.1 & 2.9 & 2.5 & 2.1 & 3.5 & 3.1 & 2.7 & 2.9 & 2.0 & 2.2 \\
\hline $46-55$ & 1.1 & 1.8 & 2.3 & 3.1 & 2.4 & 2.4 & 3.6 & 2.9 & 2.0 & 2.0 & 1.8 \\
\hline $56-65$ & 1.2 & 2.1 & 3.3 & 3.9 & 2.9 & 3.1 & 2.9 & 3.2 & 2.7 & 2.6 & 1.9 \\
\hline \multicolumn{12}{|l|}{ Education } \\
\hline Higher & 2.1 & 2.6 & 2.1 & 3.4 & 2.9 & 4.6 & 6.9 & 3.7 & 3.0 & 1.8 & 2.3 \\
\hline Higher vocational & 0.8 & 2.1 & 2.0 & 2.6 & 1.3 & 1.5 & 2.8 & 2.6 & 1.1 & 1.1 & 0.9 \\
\hline Advanced high school & 1.6 & 4.4 & 4.6 & 3.0 & 4.0 & 2.6 & 2.7 & 3.1 & 2.5 & 3.3 & 3.2 \\
\hline Apprenticeship & 1.7 & 2.1 & 3.6 & 3.5 & 2.4 & 3.2 & 3.1 & 3.1 & 2.6 & 2.3 & 1.9 \\
\hline Mandat. school or less & 2.3 & 3.2 & 4.5 & 4.9 & 5.3 & 6.5 & 6.7 & 5.6 & 5.6 & 4.6 & 5.5 \\
\hline \multicolumn{12}{|l|}{ Gender } \\
\hline Female & 2.5 & 3.1 & 4.3 & 4.0 & 3.6 & 4.1 & 3.9 & 4.1 & 3.5 & 3.0 & 3.5 \\
\hline Male & 1.1 & 2.0 & 2.9 & 3.4 & 2.6 & 3.4 & 4.2 & 3.2 & 2.6 & 2.2 & 1.7 \\
\hline \multicolumn{12}{|l|}{ Region of Residence } \\
\hline German part & 1.4 & 1.9 & 3.0 & 2.9 & 2.3 & 2.9 & 3.6 & 3.1 & 2.6 & 2.2 & 2.2 \\
\hline Latin part & 2.6 & 4.1 & 5.0 & 5.9 & 5.0 & 6.1 & 5.4 & 5.0 & 4.3 & 3.6 & 3.4 \\
\hline \# observations & 10,312 & 10,948 & 11,574 & 11,451 & 19,979 & 10,275 & 10,347 & 10,524 & 11,370 & 11,278 & 11,829 \\
\hline
\end{tabular}

Source: Swiss Labour Force Survey; own calculations.

Table B6: Weighted Sample Non-Employment Rates by Subgroup (Percent)

\begin{tabular}{|c|c|c|c|c|c|c|c|c|c|c|c|}
\hline Variable & 1991 & 1992 & 1993 & 1994 & 1995 & 1996 & 1997 & 1998 & 1999 & 2000 & 2001 \\
\hline Total sample & 21.3 & 21.1 & 22.0 & 23.0 & 22.3 & 22.5 & 23.0 & 21.7 & 21.3 & 21.3 & 20.5 \\
\hline \multicolumn{12}{|l|}{ Age } \\
\hline $16-25$ & 24.6 & 25.2 & 25.7 & 29.8 & 29.8 & 30.0 & 30.9 & 30.0 & 29.8 & 28.9 & 29.6 \\
\hline $26-35$ & 16.3 & 17.3 & 19.5 & 19.6 & 17.1 & 17.6 & 16.3 & 14.9 & 13.5 & 14.3 & 15.1 \\
\hline $36-45$ & 14.2 & 14.3 & 15.4 & 14.6 & 15.1 & 15.8 & 16.7 & 14.6 & 15.2 & 13.4 & 12.5 \\
\hline $46-55$ & 15.2 & 13.9 & 14.7 & 16.0 & 15.6 & 15.2 & 16.3 & 16.1 & 15.1 & 15.8 & 14.5 \\
\hline $56-65$ & 42.4 & 40.9 & 41.4 & 42.3 & 42.3 & 41.8 & 43.1 & 41.3 & 41.7 & 42.4 & 38.7 \\
\hline \multicolumn{12}{|l|}{ Education } \\
\hline Higher & 12.6 & 11.5 & 13.6 & 16.8 & 12.4 & 15.1 & 15.3 & 12.6 & 13.5 & 12.6 & 11.1 \\
\hline Higher vocational & 10.6 & 10.3 & 10.2 & 10.9 & 10.1 & 8.1 & 9.1 & 8.9 & 7.2 & 8.5 & 8.3 \\
\hline Advanced high school & 31.2 & 32.2 & 32.2 & 29.7 & 31.1 & 31.9 & 32.5 & 29.1 & 29.6 & 27.5 & 27.7 \\
\hline Apprenticeship & 18.1 & 17.8 & 19.4 & 20.2 & 19.4 & 20.2 & 20.1 & 19.2 & 19.0 & 18.4 & 18.4 \\
\hline Mandat. school or less & 32.5 & 32.9 & 32.8 & 34.5 & 35.0 & 35.2 & 36.1 & 34.6 & 34.3 & 36.5 & 34.0 \\
\hline \multicolumn{12}{|l|}{ Gender } \\
\hline Female & 33.3 & 32.4 & 33.0 & 33.7 & 33.3 & 32.6 & 32.3 & 30.9 & 30.4 & 30.6 & 29.3 \\
\hline Male & 9.2 & 9.9 & 11.1 & 12.3 & 11.4 & 12.5 & 13.7 & 12.5 & 12.3 & 12.1 & 11.7 \\
\hline \multicolumn{12}{|l|}{ Region of Residence } \\
\hline German part & 19.5 & 19.4 & 20.0 & 20.9 & 20.5 & 20.3 & 20.9 & 19.5 & 19.4 & 19.5 & 19.3 \\
\hline Latin part & 26.2 & 25.5 & 27.3 & 28.6 & 27.3 & 28.3 & 28.3 & 27.4 & 26.4 & 26.1 & 23.7 \\
\hline \# observations & 12,910 & 13,537 & 14,379 & 14,306 & 25,056 & 12,790 & 12,864 & 12,950 & 13,929 & 13,890 & 14,483 \\
\hline
\end{tabular}

Source: Swiss Labour Force Survey; own calculations. 
Table B7: SLFS Wage Regressions (Transformed Coefficients - t-values in Parentheses)

\begin{tabular}{|c|c|c|c|c|c|c|c|c|c|c|c|}
\hline Variable & 1991 & 1992 & 1993 & 1994 & 1995 & 1996 & 1997 & 1998 & 1999 & 2000 & 2001 \\
\hline \multirow[t]{2}{*}{1991 sample mean } & 3.43 & 3.46 & 3.46 & 3.47 & 3.46 & 3.42 & 3.42 & 3.42 & 3.44 & 3.44 & 3.45 \\
\hline & $(468.7)$ & $(526.7)$ & (498.8) & $(562.3)$ & $(613.8)$ & $(486.9)$ & $(538.5)$ & $(557.3)$ & $(569.4)$ & $(534.1)$ & (641.4) \\
\hline \multicolumn{12}{|c|}{ 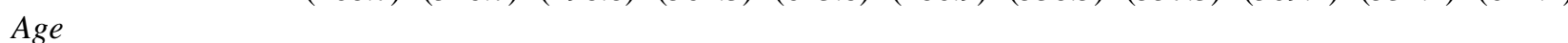 } \\
\hline \multirow[t]{2}{*}{$16-25$} & -0.29 & -0.26 & -0.29 & -0.29 & -0.32 & -0.29 & -0.29 & -0.29 & -0.2 & -0.26 & -0.27 \\
\hline & $-(17.7)$ & $-(17.5)$ & $-(17.0)$ & $-(19.3)$ & $-(21.6)$ & $-(16.4)$ & $-(18.2)$ & $-(17.9)$ & $-(16.3)$ & $-(14.5)$ & $-(19.5)$ \\
\hline \multirow[t]{2}{*}{$26-35$} & -0.01 & -0.03 & -0.04 & -0.04 & -0.04 & -0.03 & -0.03 & -0.03 & -0.03 & -0.03 & -0.02 \\
\hline & $-(0.6)$ & $-(2.7)$ & $-(4.2)$ & $-(5.2)$ & $-(5.2)$ & $-(3.3)$ & $-(2.8)$ & $-(2.9)$ & $-(3.6)$ & $-(3.9)$ & $-(2.8)$ \\
\hline \multirow[t]{2}{*}{$36-45$} & 0.11 & 0.11 & 0.13 & 0.09 & 0.11 & 0.10 & 0.10 & 0.09 & 0.07 & 0.09 & 0.08 \\
\hline & (9.4) & (10.1) & (11.2) & (9.7) & $(12.0)$ & (7.9) & (10.6) & (9.3) & (7.4) & (9.4) & (9.3) \\
\hline \multirow[t]{2}{*}{$46-55$} & 0.13 & 0.13 & 0.15 & 0.16 & 0.17 & 0.15 & 0.14 & 0.14 & 0.14 & 0.13 & 0.13 \\
\hline & $(7.2)$ & $(9.5)$ & (12.2) & $(12.0)$ & $(15.3)$ & $(12.7)$ & (13.4) & $(13.0)$ & (13.9) & (11.6) & (12.3) \\
\hline \multirow[t]{2}{*}{$56-65$} & 0.06 & 0.07 & 0.08 & 0.14 & 0.12 & 0.10 & 0.10 & 0.12 & 0.13 & 0.11 & 0.13 \\
\hline & (3.0) & (3.0) & (3.3) & (7.4) & $(8.0)$ & $(5.3)$ & (4.8) & (6.8) & (7.8) & (7.1) & $(9.0)$ \\
\hline \multicolumn{12}{|l|}{ Education } \\
\hline \multirow[t]{2}{*}{ Higher } & 0.35 & 0.36 & 0.33 & 0.37 & 0.37 & 0.38 & 0.38 & 0.37 & 0.3 & 0.35 & 0.36 \\
\hline & (13.1) & $(14.1)$ & $(13.5)$ & $(18.4)$ & $(17.2)$ & $(16.6)$ & $(20.3)$ & $(17.8)$ & & $(16.1)$ & (15.8) \\
\hline \multirow[t]{2}{*}{ Higher vocational } & 0.24 & 0.24 & 0.20 & 0.23 & 0.22 & 0.22 & 0.23 & 0.21 & 0.23 & 0.20 & 0.25 \\
\hline & (10.3) & (13.2) & $(10.1)$ & $(15.7)$ & $(15.4)$ & (14.6) & (17.2) & $(15.1)$ & & $(15.0)$ & $(20.2)$ \\
\hline \multirow[t]{2}{*}{ Advanced high sch. } & 0.15 & 0.17 & 0.21 & 0.15 & 0.19 & 0.15 & 0.16 & 0.16 & 0.15 & 0.14 & 0.11 \\
\hline & (5.3) & (5.6) & $(6.4)$ & (6.3) & (7.6) & $(5.0)$ & $(6.2)$ & $(7.6)$ & (7.4) & (6.3) & $(6.0)$ \\
\hline \multirow[t]{2}{*}{ Apprenticeship } & -0.01 & -0.02 & -0.01 & -0.02 & -0.02 & -0.01 & -0.02 & -0.01 & -0.03 & -0.01 & -0.02 \\
\hline & $-(1.8)$ & $-(3.0)$ & $-(1.3)$ & $-(3.6)$ & $-(3.4)$ & $-(2.2)$ & $-(3.5)$ & $-(2.0)$ & $-(4.8)$ & $-(1.5)$ & $-(3.4)$ \\
\hline \multirow[t]{2}{*}{ Mandatory or less } & -0.27 & -0.26 & -0.27 & -0.25 & -0.27 & -0.27 & -0.26 & -0.26 & -0.24 & -0.25 & -0.25 \\
\hline & $-(17.2)$ & $-(19.7)$ & $-(16.8)$ & $-(16.9)$ & $-(22.6)$ & $-(16.3)$ & $-(16.7)$ & $-(19.3)$ & $-(15.2)$ & $-(16.8)$ & $-(20.8)$ \\
\hline \multicolumn{12}{|l|}{ Gender } \\
\hline \multirow[t]{2}{*}{ Female } & -0.13 & -0.12 & -0.11 & -0.12 & -0.11 & -0.11 & -0.11 & -0.12 & -0.10 & -0.11 & -0.11 \\
\hline & $-(16.5)$ & $-(16.4)$ & $-(14.3)$ & $-(16.9)$ & $-(17.6)$ & $-(14.5)$ & $-(15.9)$ & $-(17.6)$ & $-(16.3)$ & $-(16.1)$ & $-(18.5)$ \\
\hline \multirow[t]{2}{*}{ Male } & 0.10 & 0.09 & 0.08 & 0.09 & 0.08 & 0.08 & 0.08 & 0.09 & 0.08 & 0.08 & 0.08 \\
\hline & $(16.5)$ & (16.4) & $(14.3)$ & (16.9) & $(17.6)$ & $(14.5)$ & (15.9) & (17.6) & $(16.3)$ & $(16.1)$ & $(18.5)$ \\
\hline \multicolumn{12}{|l|}{ Region of Residence } \\
\hline \multirow[t]{2}{*}{ German part } & 0.01 & 0.02 & 0.01 & 0.01 & 0.01 & 0.01 & 0.01 & 0.02 & 0.01 & 0.01 & 0.01 \\
\hline & $(2.5)$ & $(4.1)$ & $(3.6)$ & $(3.7)$ & (3.4) & $(3.3)$ & $(2.4)$ & $(4.4)$ & $(2.0)$ & $(3.6)$ & $(3.8)$ \\
\hline \multirow[t]{2}{*}{ Latin part } & -0.03 & -0.04 & -0.04 & -0.03 & -0.03 & -0.04 & -0.02 & -0.04 & -0.02 & -0.04 & -0.03 \\
\hline & $-(2.5)$ & $-(4.1)$ & $-(3.6)$ & $-(3.7)$ & $-(3.4)$ & $-(3.3)$ & $-(2.4)$ & $-(4.4)$ & $-(2.0)$ & $-(3.6)$ & $-(3.8)$ \\
\hline$\overline{\mathrm{R}^{2}}$ & 0.26 & 0.27 & 0.25 & 0.29 & 0.27 & 0.27 & 0.29 & 0.29 & 0.28 & 0.25 & 0.29 \\
\hline \# observations & 6,791 & 7,424 & 7,737 & 7,789 & 13,043 & 7,072 & 7,098 & 7,231 & 7,959 & 7,801 & 8,313 \\
\hline
\end{tabular}

Source: Swiss Labor Force Survey (SLFS); own calculations. 
Table B8: WSS Wage Regressions (Transformed Coefficients - t-values in Parentheses)

\begin{tabular}{|c|c|c|c|c|}
\hline Variable & 1994 & 1996 & 1998 & 2000 \\
\hline 1991 sample mean & $\begin{array}{c}8.54 \\
(8190.2)\end{array}$ & $\begin{array}{c}8.53 \\
(8443.2)\end{array}$ & $\begin{array}{c}8.54 \\
(8927.4)\end{array}$ & $\begin{array}{c}8.54 \\
(9423.3)\end{array}$ \\
\hline \multicolumn{5}{|c|}{ (2) } \\
\hline $16-25$ & $\begin{array}{c}-0.26 \\
-(117.3)\end{array}$ & $\begin{array}{c}-0.26 \\
-(112.1)\end{array}$ & $\begin{array}{c}-0.27 \\
-(123.0)\end{array}$ & $\begin{array}{c}-0.25 \\
-(122.1)\end{array}$ \\
\hline $26-35$ & $\begin{array}{c}-0.06 \\
-(40.0)\end{array}$ & $\begin{array}{c}-0.05 \\
-(37.0)\end{array}$ & $\begin{array}{c}-0.06 \\
-(39.4)\end{array}$ & $\begin{array}{c}-0.05 \\
-(38.0)\end{array}$ \\
\hline $36-45$ & $\begin{array}{c}0.08 \\
(41.2)\end{array}$ & $\begin{array}{c}0.07 \\
(38.0)\end{array}$ & $\begin{array}{c}0.07 \\
(41.8)\end{array}$ & $\begin{array}{c}0.07 \\
(41.3)\end{array}$ \\
\hline $46-55$ & $\begin{array}{c}0.13 \\
(59.0)\end{array}$ & $\begin{array}{c}0.13 \\
(61.7)\end{array}$ & $\begin{array}{c}0.13 \\
(65.3)\end{array}$ & $\begin{array}{l}0.13 \\
(64.9)\end{array}$ \\
\hline $56-65$ & $\begin{array}{c}0.12 \\
(34.2)\end{array}$ & $\begin{array}{c}0.13 \\
(35.5)\end{array}$ & $\begin{array}{c}0.14 \\
(38.7)\end{array}$ & $\begin{array}{c}0.13 \\
(40.9)\end{array}$ \\
\hline \multicolumn{5}{|l|}{ Education } \\
\hline Higher & $\begin{array}{c}0.54 \\
(73.5)\end{array}$ & $\begin{array}{c}0.50 \\
(76.8)\end{array}$ & $\begin{array}{c}0.54 \\
(88.0)\end{array}$ & $\begin{array}{c}0.55 \\
(106.2)\end{array}$ \\
\hline Higher vocational & $\begin{array}{c}0.30 \\
(85.5)\end{array}$ & $\begin{array}{c}0.27 \\
(79.7)\end{array}$ & $\begin{array}{c}0.31 \\
(103.3)\end{array}$ & $\begin{array}{c}0.33 \\
(110.8)\end{array}$ \\
\hline Advanced high sch. & $\begin{array}{c}0.17 \\
(17.2)\end{array}$ & $\begin{array}{c}0.21 \\
(25.2)\end{array}$ & $\begin{array}{c}0.20 \\
(21.8)\end{array}$ & $\begin{array}{c}0.24 \\
(25.2)\end{array}$ \\
\hline Apprenticeship & $\begin{array}{c}0.03 \\
(28.3)\end{array}$ & $\begin{array}{c}0.03 \\
(29.2)\end{array}$ & $\begin{array}{c}0.03 \\
(27.7)\end{array}$ & $\begin{array}{c}0.02 \\
(18.2)\end{array}$ \\
\hline Mandatory or less & $\begin{array}{c}-0.23 \\
-(151.5)\end{array}$ & $\begin{array}{c}-0.21 \\
-(138.6)\end{array}$ & $\begin{array}{c}-0.23 \\
-(154.5)\end{array}$ & $\begin{array}{c}-0.22 \\
-(164.8)\end{array}$ \\
\hline Other & $\begin{array}{c}-0.14 \\
-(14.9)\end{array}$ & $\begin{array}{l}-0.16 \\
-(24.9)\end{array}$ & $\begin{array}{l}-0.15 \\
-(27.5)\end{array}$ & $\begin{array}{c}-0.10 \\
-(23.0)\end{array}$ \\
\hline Gender & & & & \\
\hline Female & $\begin{array}{c}-0.12 \\
-(90.9)\end{array}$ & $\begin{array}{c}-0.12 \\
-(89.9)\end{array}$ & $\begin{array}{c}-0.12 \\
-(92.0)\end{array}$ & $\begin{array}{c}-0.11 \\
-(95.8)\end{array}$ \\
\hline Male & $\begin{array}{c}0.07 \\
(90.9)\end{array}$ & $\begin{array}{c}0.07 \\
(89.9)\end{array}$ & $\begin{array}{c}0.07 \\
(92.0)\end{array}$ & $\begin{array}{c}0.07 \\
(95.8)\end{array}$ \\
\hline Region of Residen & & & & \\
\hline German part & $\begin{array}{c}0.01 \\
(14.9)\end{array}$ & $\begin{array}{c}0.01 \\
(14.2)\end{array}$ & $\begin{array}{c}0.01 \\
(17.8)\end{array}$ & $\begin{array}{c}0.01 \\
(22.1)\end{array}$ \\
\hline Latin part & $\begin{array}{c}-0.03 \\
-(14.9)\end{array}$ & $\begin{array}{c}-0.03 \\
-(14.2)\end{array}$ & $\begin{array}{c}-0.03 \\
-(17.8)\end{array}$ & $\begin{array}{c}-0.03 \\
-(22.1)\end{array}$ \\
\hline $\begin{array}{l}\mathrm{R}^{2} \\
\# \text { observations }\end{array}$ & $\begin{array}{c}0.48 \\
376,289\end{array}$ & $\begin{array}{c}0.45 \\
378,004\end{array}$ & $\begin{array}{c}0.47 \\
357,803\end{array}$ & $\begin{array}{c}0.45 \\
437,505\end{array}$ \\
\hline
\end{tabular}

Source: Swiss Wage Structure Survey (WSS) (BFS, Lohnstrukturerhebung); own calculations. 
Table B9: Unemployment Regressions (Transformed Coefficients - t-values in Parentheses)

\begin{tabular}{|c|c|c|c|c|c|c|c|c|c|c|c|}
\hline Variable & 1991 & 1992 & 1993 & 1994 & 1995 & 1996 & 1997 & 1998 & 1999 & 2000 & 2001 \\
\hline \multirow[t]{2}{*}{1991 sample mean } & -2.19 & -2.01 & -1.84 & -1.83 & -1.94 & -1.84 & -1.78 & -1.82 & -1.93 & -1.97 & -2.04 \\
\hline & $-(52.8)$ & $-(59.2)$ & $-(61.1)$ & $-(59.0)$ & $-(70.2)$ & $-(60.0)$ & $-(62.7)$ & $-(53.6)$ & $-(56.4)$ & $-(57.9)$ & $-(55.7)$ \\
\hline \multicolumn{12}{|c|}{ 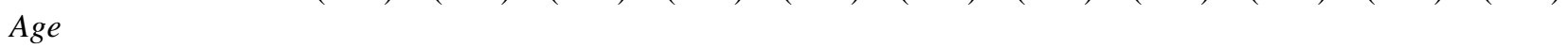 } \\
\hline \multirow[t]{2}{*}{$16-25$} & 0.27 & 0.18 & 0.19 & 0.20 & 0.13 & 0.10 & 0.15 & 0.19 & 0.23 & 0.20 & 0.26 \\
\hline & $(4.0)$ & (2.8) & (3.2) & (3.3) & (2.3) & (1.4) & $(2.5)$ & $(2.5)$ & (3.2) & $(2.5)$ & $(3.3)$ \\
\hline \multirow[t]{2}{*}{$26-35$} & 0.02 & 0.05 & 0.06 & 0.03 & 0.09 & 0.10 & 0.08 & 0.04 & -0.05 & 0.01 & -0.06 \\
\hline & $(0.4)$ & $(1.0)$ & (1.2) & $(0.5)$ & $(2.1)$ & (1.7) & $(1.5)$ & $(0.8)$ & $-(0.8)$ & $(0.1)$ & $-(0.9)$ \\
\hline \multirow[t]{2}{*}{$36-45$} & -0.10 & -0.06 & -0.07 & -0.17 & -0.15 & 0.00 & -0.11 & -0.11 & 0.00 & -0.09 & 0.00 \\
\hline & $-(1.4)$ & $-(1.1)$ & $-(1.4)$ & $-(3.1)$ & $-(3.3)$ & $(0.0)$ & $-(2.0)$ & $-(1.6)$ & $(0.1)$ & $-(1.4)$ & $-(0.1)$ \\
\hline \multirow[t]{2}{*}{$46-55$} & -0.14 & -0.14 & -0.17 & -0.06 & -0.08 & -0.19 & -0.04 & -0.10 & -0.15 & -0.10 & -0.12 \\
\hline & $-(1.7)$ & $-(2.0)$ & $-(2.7)$ & $-(1.0)$ & $-(1.5)$ & $-(3.2)$ & $-(0.7)$ & $-(1.6)$ & $-(2.4)$ & $-(1.5)$ & $-(1.9)$ \\
\hline \multirow[t]{2}{*}{$56-65$} & -0.07 & -0.05 & -0.01 & 0.04 & 0.02 & -0.06 & -0.15 & -0.04 & -0.04 & 0.01 & -0.08 \\
\hline & $-(0.6)$ & $-(0.5)$ & $-(0.1)$ & $(0.5)$ & $(0.2)$ & $-(0.8)$ & $-(1.8)$ & $-(0.5)$ & $-(0.5)$ & $(0.1)$ & $-(0.9)$ \\
\hline \multicolumn{12}{|l|}{ Education } \\
\hline \multirow[t]{2}{*}{ Higher } & 0.16 & 0.08 & -0.19 & -0.01 & 0.00 & 0.11 & 0.29 & 0.04 & 0.04 & -0.09 & 0.07 \\
\hline & (1.4) & $(0.7)$ & $-(2.1)$ & $-(0.1)$ & $(0.0)$ & $(0.9)$ & $(2.6)$ & $(0.3)$ & $(0.3)$ & $-(0.7)$ & $(0.7)$ \\
\hline \multirow[t]{2}{*}{ Higher vocational } & -0.16 & 0.00 & -0.16 & -0.08 & -0.25 & -0.31 & -0.11 & -0.07 & -0.29 & -0.28 & -0.28 \\
\hline & $-(1.4)$ & $(0.0)$ & $-(1.9)$ & $-(0.9)$ & $-(3.1)$ & $-(3.5)$ & $-(1.3)$ & $-(0.7)$ & $-(2.2)$ & $-(3.0)$ & $-(2.7)$ \\
\hline \multirow[t]{2}{*}{ Advanced high sch. } & -0.12 & 0.18 & 0.06 & -0.13 & 0.11 & -0.18 & -0.17 & -0.09 & -0.11 & 0.07 & 0.06 \\
\hline & $-(1.0)$ & $(1.7)$ & $(0.6)$ & $-(1.1)$ & $(1.2)$ & $-(1.4)$ & $-(1.6)$ & $-(0.7)$ & $-(1.0)$ & $(0.7)$ & $(0.5)$ \\
\hline \multirow[t]{2}{*}{ Apprenticeship } & 0.00 & -0.06 & 0.03 & 0.00 & -0.06 & -0.03 & -0.09 & -0.04 & -0.02 & -0.02 & -0.08 \\
\hline & $(0.0)$ & $-(2.0)$ & $(1.1)$ & $(0.1)$ & $-(2.4)$ & $-(1.0)$ & $-(3.2)$ & $-(1.4)$ & $-(0.7)$ & $-(0.6)$ & $-(2.4)$ \\
\hline \multirow[t]{2}{*}{ Mandatory or less } & 0.07 & 0.08 & 0.07 & 0.09 & 0.26 & 0.28 & 0.25 & 0.17 & 0.25 & 0.23 & 0.33 \\
\hline & $(1.0)$ & (1.3) & $(1.2)$ & $(1.5)$ & $(5.3)$ & $(4.1)$ & (4.3) & $(2.7)$ & $(4.1)$ & (3.1) & $(4.8)$ \\
\hline \multicolumn{12}{|l|}{ Gender } \\
\hline \multirow[t]{2}{*}{ Female } & 0.17 & 0.10 & 0.08 & 0.04 & 0.05 & 0.03 & -0.02 & 0.06 & 0.06 & 0.06 & 0.18 \\
\hline & $(4.1)$ & $(2.7)$ & $(2.3)$ & $(1.1)$ & $(1.7)$ & $(0.9)$ & $-(0.7)$ & $(1.5)$ & $(1.7)$ & (1.4) & $(4.2)$ \\
\hline \multirow[t]{2}{*}{ Male } & -0.13 & -0.07 & -0.06 & -0.03 & -0.04 & -0.02 & 0.02 & -0.04 & -0.05 & -0.04 & -0.13 \\
\hline & $-(4.1)$ & $-(2.7)$ & $-(2.3)$ & $-(1.1)$ & $-(1.7)$ & $-(0.9)$ & $(0.7)$ & $-(1.5)$ & $-(1.7)$ & $-(1.4)$ & $-(4.2)$ \\
\hline \multicolumn{12}{|l|}{ Region of Residence } \\
\hline \multirow[t]{2}{*}{ German part } & -0.06 & -0.08 & -0.06 & -0.09 & -0.09 & -0.08 & -0.04 & -0.06 & -0.06 & -0.05 & -0.05 \\
\hline & $-(3.4)$ & $-(4.7)$ & $-(4.0)$ & $-(5.9)$ & $-(6.9)$ & $-(4.7)$ & $-(2.6)$ & $-(3.1)$ & $-(3.4)$ & $-(2.6)$ & $-(2.3)$ \\
\hline \multirow[t]{2}{*}{ Latin part } & 0.18 & 0.23 & 0.17 & 0.25 & 0.25 & 0.24 & 0.13 & 0.17 & 0.17 & 0.15 & 0.13 \\
\hline & $(3.4)$ & $(4.7)$ & $(4.0)$ & $(5.9)$ & $(6.9)$ & $(4.7)$ & $(2.6)$ & $(3.1)$ & $(3.4)$ & $(2.6)$ & $(2.3)$ \\
\hline Log Likelihood & -857.0 & -1243.5 & -1719.4 & -1743.8 & -2585.9 & -1565.4 & -1711.7 & -1589.8 & -1476.4 & -1312.9 & -1308.3 \\
\hline \# observations & 10,312 & 10,948 & 11,574 & 11,451 & 19,979 & 10,275 & 10,347 & 10,524 & 11,370 & 11,278 & 11,829 \\
\hline
\end{tabular}

Source: Swiss Labor Force Survey; own calculations. 
Table B10: Degree of Unemployment Regressions (Transformed Coefficients - t-values in Parentheses)

\begin{tabular}{|c|c|c|c|c|c|c|c|c|c|c|c|}
\hline Variable & 1991 & 1992 & 1993 & 1994 & 1995 & 1996 & 1997 & 1998 & 1999 & 2000 & 2001 \\
\hline 1991 sample mean & $\begin{array}{c}1.35 \\
(10.6)\end{array}$ & $\begin{array}{c}2.04 \\
(13.3)\end{array}$ & $\begin{array}{c}3.04 \\
(15.6)\end{array}$ & $\begin{array}{c}3.38 \\
(16.1)\end{array}$ & $\begin{array}{c}2.66 \\
(18.2)\end{array}$ & $\begin{array}{c}3.46 \\
(13.5)\end{array}$ & $\begin{array}{c}3.75 \\
(15.9)\end{array}$ & $\begin{array}{c}3.48 \\
(13.5)\end{array}$ & $\begin{array}{c}2.84 \\
(13.3)\end{array}$ & $\begin{array}{c}2.25 \\
(12.0)\end{array}$ & $\begin{array}{c}2.10 \\
(10.2)\end{array}$ \\
\hline \multicolumn{12}{|l|}{ Age } \\
\hline $16-25$ & $\begin{array}{l}1.23 \\
(3.4)\end{array}$ & $\begin{array}{l}1.06 \\
(2.6)\end{array}$ & $\begin{array}{l}1.65 \\
(3.0)\end{array}$ & $\begin{array}{l}1.61 \\
(2.8)\end{array}$ & $\begin{array}{l}0.94 \\
(2.4)\end{array}$ & $\begin{array}{l}0.90 \\
(1.3)\end{array}$ & $\begin{array}{l}1.25 \\
(2.0)\end{array}$ & $\begin{array}{l}1.64 \\
(2.2)\end{array}$ & $\begin{array}{l}1.66 \\
(2.4)\end{array}$ & $\begin{array}{l}0.98 \\
(1.7)\end{array}$ & $\begin{array}{l}1.71 \\
(2.6)\end{array}$ \\
\hline $26-35$ & $\begin{array}{l}-0.11 \\
-(0.6)\end{array}$ & $\begin{array}{l}0.32 \\
(1.2)\end{array}$ & $\begin{array}{l}0.30 \\
(0.9)\end{array}$ & $\begin{array}{l}0.04 \\
(0.1)\end{array}$ & $\begin{array}{l}0.37 \\
(1.4)\end{array}$ & $\begin{array}{l}0.95 \\
(1.9)\end{array}$ & $\begin{array}{l}0.68 \\
(1.6)\end{array}$ & $\begin{array}{l}0.54 \\
(1.2)\end{array}$ & $\begin{array}{l}-0.33 \\
-(1.0)\end{array}$ & $\begin{array}{l}0.14 \\
(0.5)\end{array}$ & $\begin{array}{l}-0.49 \\
-(1.8)\end{array}$ \\
\hline $36-45$ & $\begin{array}{l}-0.28 \\
-(1.4)\end{array}$ & $\begin{array}{l}-0.37 \\
-(1.4)\end{array}$ & $\begin{array}{l}-0.70 \\
-(2.3)\end{array}$ & $\begin{array}{l}-1.09 \\
-(3.4)\end{array}$ & $\begin{array}{l}-0.68 \\
-(3.2)\end{array}$ & $\begin{array}{l}-0.38 \\
-(0.9)\end{array}$ & $\begin{array}{l}-0.77 \\
-(2.0)\end{array}$ & $\begin{array}{l}-1.14 \\
-(2.7)\end{array}$ & $\begin{array}{l}-0.24 \\
-(0.7)\end{array}$ & $\begin{array}{l}-0.50 \\
-(1.8)\end{array}$ & $\begin{array}{l}-0.31 \\
-(1.1)\end{array}$ \\
\hline $46-55$ & $\begin{array}{l}-0.60 \\
-(2.9)\end{array}$ & $\begin{array}{l}-0.84 \\
-(3.5)\end{array}$ & $\begin{array}{l}-1.05 \\
-(3.4)\end{array}$ & $\begin{array}{l}-0.46 \\
-(1.2)\end{array}$ & $\begin{array}{l}-0.61 \\
-(2.5)\end{array}$ & $\begin{array}{l}-1.23 \\
-(3.3)\end{array}$ & $\begin{array}{l}-0.45 \\
-(1.1)\end{array}$ & $\begin{array}{l}-0.85 \\
-(2.2)\end{array}$ & $\begin{array}{l}-0.84 \\
-(2.8)\end{array}$ & $\begin{array}{l}-0.59 \\
-(2.0)\end{array}$ & $\begin{array}{l}-0.54 \\
-(1.9)\end{array}$ \\
\hline $56-65$ & $\begin{array}{l}-0.24 \\
-(0.7)\end{array}$ & $\begin{array}{l}-0.35 \\
-(0.9)\end{array}$ & $\begin{array}{l}-0.28 \\
-(0.5)\end{array}$ & $\begin{array}{l}0.15 \\
(0.3)\end{array}$ & $\begin{array}{l}-0.01 \\
(0.0)\end{array}$ & $\begin{array}{l}-0.82 \\
-(1.8)\end{array}$ & $\begin{array}{l}-1.37 \\
-(2.7)\end{array}$ & $\begin{array}{l}-0.26 \\
-(0.5)\end{array}$ & $\begin{array}{l}-0.18 \\
-(0.4)\end{array}$ & $\begin{array}{l}0.03 \\
(0.1)\end{array}$ & $\begin{array}{l}-0.25 \\
-(0.7)\end{array}$ \\
\hline Education & & & & & & & & & & & \\
\hline High & $\begin{array}{l}0.72 \\
(1.4)\end{array}$ & $\begin{array}{l}0.50 \\
(0.9)\end{array}$ & $\begin{array}{l}-0.77 \\
-(1.7)\end{array}$ & $\begin{array}{l}0.51 \\
(0.6)\end{array}$ & $\begin{array}{l}-0.24 \\
-(0.6)\end{array}$ & $\begin{array}{l}1.35 \\
(1.1)\end{array}$ & $\begin{array}{l}1.41 \\
(1.3)\end{array}$ & $\begin{array}{l}0.48 \\
(0.5)\end{array}$ & $\begin{array}{l}0.21 \\
(0.3)\end{array}$ & $\begin{array}{l}-0.45 \\
-(0.8)\end{array}$ & $\begin{array}{l}0.35 \\
(0.6)\end{array}$ \\
\hline Higher vocational & $\begin{array}{l}-0.21 \\
-(0.8)\end{array}$ & $\begin{array}{l}0.20 \\
(0.5)\end{array}$ & $\begin{array}{l}-0.78 \\
-(1.9)\end{array}$ & $\begin{array}{l}-0.89 \\
-(1.9)\end{array}$ & $\begin{array}{l}-1.13 \\
-(4.0)\end{array}$ & $\begin{array}{l}-1.61 \\
-(3.9)\end{array}$ & $\begin{array}{l}-0.88 \\
-(1.5)\end{array}$ & $\begin{array}{l}-0.54 \\
-(0.8)\end{array}$ & $\begin{array}{l}-1.23 \\
-(2.8)\end{array}$ & $\begin{array}{l}-1.12 \\
-(4.0)\end{array}$ & $\begin{array}{l}-0.83 \\
-(3.1)\end{array}$ \\
\hline Advan & $\begin{array}{l}-0.52 \\
-(1.3)\end{array}$ & $\begin{array}{l}1.37 \\
(1.6)\end{array}$ & $\begin{array}{l}-0.33 \\
-(0.5)\end{array}$ & $\begin{array}{l}-0.82 \\
-(1.2)\end{array}$ & $\begin{array}{l}1.04 \\
(1.4)\end{array}$ & $\begin{array}{l}-1.73 \\
-(2.9)\end{array}$ & $\begin{array}{l}-1.39 \\
-(2.2)\end{array}$ & $\begin{array}{l}-1.08 \\
-(1.3)\end{array}$ & $\begin{array}{l}-1.30 \\
-(2.7)\end{array}$ & $\begin{array}{l}0.28 \\
(0.5)\end{array}$ & $\begin{array}{l}0.11 \\
(0.2)\end{array}$ \\
\hline Appre & $\begin{array}{l}-0.06 \\
-(0.5)\end{array}$ & $\begin{array}{l}-0.31 \\
-(2.2)\end{array}$ & $\begin{array}{l}0.23 \\
(1.3)\end{array}$ & $\begin{array}{l}0.02 \\
(0.1)\end{array}$ & $\begin{array}{l}-0.39 \\
-(2.8)\end{array}$ & $\begin{array}{l}-0.53 \\
-(2.2)\end{array}$ & $\begin{array}{l}-0.70 \\
-(3.1)\end{array}$ & $\begin{array}{l}-0.26 \\
-(1.2)\end{array}$ & $\begin{array}{l}-0.30 \\
-(1.6)\end{array}$ & $\begin{array}{l}-0.29 \\
-(1.6)\end{array}$ & $\begin{array}{l}-0.56 \\
-(3.2)\end{array}$ \\
\hline Manc & $\begin{array}{l}0.18 \\
(0.6)\end{array}$ & $\begin{array}{l}0.13 \\
(0.4)\end{array}$ & $\begin{array}{l}0.22 \\
(0.5)\end{array}$ & $\begin{array}{l}0.54 \\
(1.2)\end{array}$ & $\begin{array}{l}1.47 \\
(3.6)\end{array}$ & $\begin{array}{l}2.39 \\
(3.2)\end{array}$ & $\begin{array}{l}2.28 \\
(3.7)\end{array}$ & $\begin{array}{l}1.16 \\
(2.1)\end{array}$ & $\begin{array}{l}1.83 \\
(3.5)\end{array}$ & $\begin{array}{l}1.50 \\
(2.8)\end{array}$ & $\begin{array}{l}1.82 \\
(3.2)\end{array}$ \\
\hline Gender & & & & & & & & & & & \\
\hline Female & $\begin{array}{l}0.33 \\
(2.2)\end{array}$ & $\begin{array}{l}0.15 \\
(0.8)\end{array}$ & $\begin{array}{l}0.00 \\
(0.0)\end{array}$ & $\begin{array}{l}-0.20 \\
-(0.8)\end{array}$ & $\begin{array}{l}0.02 \\
(0.1)\end{array}$ & $\begin{array}{l}-0.14 \\
-(0.5)\end{array}$ & $\begin{array}{l}-0.59 \\
-(2.2)\end{array}$ & $\begin{array}{l}0.27 \\
(0.9)\end{array}$ & $\begin{array}{l}0.11 \\
(0.4)\end{array}$ & $\begin{array}{l}-0.12 \\
-(0.6)\end{array}$ & $\begin{array}{l}0.49 \\
(2.3)\end{array}$ \\
\hline Male & $\begin{array}{l}-0.24 \\
-(2.2)\end{array}$ & $\begin{array}{l}-0.11 \\
-(0.8)\end{array}$ & $\begin{array}{l}0.00 \\
(0.0)\end{array}$ & $\begin{array}{l}0.15 \\
(0.8)\end{array}$ & $\begin{array}{l}-0.01 \\
-(0.1)\end{array}$ & $\begin{array}{l}0.10 \\
(0.5)\end{array}$ & $\begin{array}{l}0.44 \\
(2.2)\end{array}$ & $\begin{array}{l}-0.20 \\
-(0.9)\end{array}$ & $\begin{array}{l}-0.08 \\
-(0.4)\end{array}$ & $\begin{array}{l}0.09 \\
(0.6)\end{array}$ & $\begin{array}{l}-0.37 \\
-(2.3)\end{array}$ \\
\hline negt & & & & & & & & & & & \\
\hline Germ & $\begin{array}{l}-0.24 \\
-(3.0)\end{array}$ & $\begin{array}{l}-0.48 \\
-(4.6)\end{array}$ & $\begin{array}{l}-0.51 \\
-(4.2)\end{array}$ & $\begin{array}{l}-0.81 \\
-(5.9)\end{array}$ & $\begin{array}{l}-0.78 \\
-(8.3)\end{array}$ & $\begin{array}{l}-0.88 \\
-(4.7)\end{array}$ & $\begin{array}{l}-0.54 \\
-(3.3)\end{array}$ & $\begin{array}{l}-0.55 \\
-(3.2)\end{array}$ & $\begin{array}{l}-0.43 \\
-(3.3)\end{array}$ & $\begin{array}{l}-0.26 \\
-(2.3)\end{array}$ & $\begin{array}{l}-0.28 \\
-(2.3)\end{array}$ \\
\hline Latin part & $\begin{array}{l}0.68 \\
(3.0)\end{array}$ & $\begin{array}{l}1.38 \\
(4.6) \\
\end{array}$ & $\begin{array}{l}1.45 \\
(4.2) \\
\end{array}$ & $\begin{array}{l}2.31 \\
(5.9) \\
\end{array}$ & $\begin{array}{l}2.24 \\
(8.3) \\
\end{array}$ & $\begin{array}{l}2.52 \\
(4.7)\end{array}$ & $\begin{array}{l}1.55 \\
(3.3)\end{array}$ & $\begin{array}{l}1.58 \\
(3.2)\end{array}$ & $\begin{array}{l}1.23 \\
(3.3)\end{array}$ & $\begin{array}{l}0.75 \\
(2.3)\end{array}$ & $\begin{array}{l}0.82 \\
(2.3) \\
\end{array}$ \\
\hline $\begin{array}{l}\mathrm{R}^{2} \\
\# \text { observations }\end{array}$ & $\begin{array}{c}0.01 \\
10,299\end{array}$ & $\begin{array}{c}0.01 \\
10,939\end{array}$ & $\begin{array}{c}0.01 \\
11,571\end{array}$ & $\begin{array}{c}0.01 \\
11,444\end{array}$ & $\begin{array}{c}0.01 \\
19,969\end{array}$ & $\begin{array}{c}0.02 \\
10,267\end{array}$ & $\begin{array}{c}0.01 \\
10,342\end{array}$ & $\begin{array}{c}0.01 \\
10,522\end{array}$ & $\begin{array}{c}0.01 \\
11,367\end{array}$ & $\begin{array}{c}0.01 \\
11,273\end{array}$ & $\begin{array}{c}0.01 \\
11,827\end{array}$ \\
\hline
\end{tabular}

Note: The low $\mathrm{R}^{2}$ of only 1 percent can be explained by the large number of workers who are 0-percent unemployed (about 96 percent of the sample). There is also some clustering at 100-percent unemployment. Alternative estimation results based on a Tobit model with double censoring revealed almost the same classification results as the displayed OLS estimates.

Source: Swiss Labor Force Survey; own calculations. 
Table B11: Non-Employment Regressions (Transformed Coefficients - t-values in Parentheses)

\begin{tabular}{|c|c|c|c|c|c|c|c|c|c|c|c|}
\hline Vari & 1991 & 1992 & 1993 & 1994 & 1995 & 1996 & 1997 & 1998 & 1999 & 2000 & 2001 \\
\hline $1991 \mathrm{sam}_{\mathrm{l}}$ & $\begin{array}{c}-0.95 \\
-(56.3)\end{array}$ & $\begin{array}{c}-0.94 \\
-(55.5)\end{array}$ & $\begin{array}{c}-0.88 \\
-(52.6)\end{array}$ & $\begin{array}{c}-0.84 \\
-(50.9)\end{array}$ & $\begin{array}{c}-0.87 \\
-(65.2)\end{array}$ & $\begin{array}{c}-0.85 \\
-(50.3)\end{array}$ & $\begin{array}{c}-0.82 \\
-(48.9)\end{array}$ & $\begin{array}{l}-0.87 \\
-(52.2)\end{array}$ & $\begin{array}{c}-0.90 \\
-(54.3)\end{array}$ & $\begin{array}{c}-0.90 \\
-(54.5)\end{array}$ & $\begin{array}{c}-0.91 \\
-(53.9)\end{array}$ \\
\hline \multicolumn{12}{|l|}{ Age } \\
\hline $16-25$ & $\begin{array}{l}0.14 \\
(4.3)\end{array}$ & $\begin{array}{l}0.14 \\
(4.2)\end{array}$ & $\begin{array}{l}0.11 \\
(3.4)\end{array}$ & $\begin{array}{l}0.21 \\
(6.2)\end{array}$ & $\begin{array}{l}0.21 \\
(7.6)\end{array}$ & $\begin{array}{l}0.18 \\
(4.9)\end{array}$ & $\begin{array}{l}0.17 \\
(5.0)\end{array}$ & $\begin{array}{l}0.20 \\
(5.5)\end{array}$ & $\begin{array}{l}0.20 \\
(5.3)\end{array}$ & $\begin{array}{l}0.17 \\
(4.5)\end{array}$ & $\begin{array}{l}0.21 \\
(5.6)\end{array}$ \\
\hline $26-35$ & $\begin{array}{l}-0.14 \\
-(5.3)\end{array}$ & $\begin{array}{l}-0.09 \\
-(3.3)\end{array}$ & $\begin{array}{l}-0.06 \\
-(2.1)\end{array}$ & $\begin{array}{l}-0.08 \\
-(2.9)\end{array}$ & $\begin{array}{l}-0.15 \\
-(6.5)\end{array}$ & $\begin{array}{l}-0.13 \\
-(4.3)\end{array}$ & $\begin{array}{l}-0.20 \\
-(6.6)\end{array}$ & $\begin{array}{l}-0.20 \\
-(6.9)\end{array}$ & $\begin{array}{l}-0.25 \\
-(8.2)\end{array}$ & $\begin{array}{l}-0.20 \\
-(6.7)\end{array}$ & $\begin{array}{l}-0.15 \\
-(4.9)\end{array}$ \\
\hline $36-45$ & $\begin{array}{l}-0.26 \\
-(8.5)\end{array}$ & $\begin{array}{l}-0.24 \\
-(8.2)\end{array}$ & $\begin{array}{l}-0.23 \\
-(7.9)\end{array}$ & $\begin{array}{c}-0.30 \\
-(10.3)\end{array}$ & $\begin{array}{c}-0.25 \\
-(10.8)\end{array}$ & $\begin{array}{l}-0.22 \\
-(6.9)\end{array}$ & $\begin{array}{l}-0.18 \\
-(5.7)\end{array}$ & $\begin{array}{l}-0.23 \\
-(7.4)\end{array}$ & $\begin{array}{l}-0.18 \\
-(6.1)\end{array}$ & $\begin{array}{l}-0.24 \\
-(8.1)\end{array}$ & $\begin{array}{l}-0.26 \\
-(8.2)\end{array}$ \\
\hline $46-55$ & $\begin{array}{l}-0.22 \\
-(6.4)\end{array}$ & $\begin{array}{l}-0.29 \\
-(8.0)\end{array}$ & $\begin{array}{l}-0.28 \\
-(8.1)\end{array}$ & $\begin{array}{l}-0.25 \\
-(7.6)\end{array}$ & $\begin{array}{l}-0.26 \\
-(9.6)\end{array}$ & $\begin{array}{l}-0.28 \\
-(8.5)\end{array}$ & $\begin{array}{l}-0.23 \\
-(7.1)\end{array}$ & $\begin{array}{l}-0.20 \\
-(6.2)\end{array}$ & $\begin{array}{l}-0.22 \\
-(6.9)\end{array}$ & $\begin{array}{l}-0.19 \\
-(5.7)\end{array}$ & $\begin{array}{l}-0.23 \\
-(7.2)\end{array}$ \\
\hline $56-65$ & $\begin{array}{c}0.67 \\
(20.5)\end{array}$ & $\begin{array}{c}0.63 \\
(19.2)\end{array}$ & $\begin{array}{c}0.60 \\
(18.9)\end{array}$ & $\begin{array}{c}0.58 \\
(18.6)\end{array}$ & $\begin{array}{c}0.62 \\
(24.4)\end{array}$ & $\begin{array}{c}0.61 \\
(18.9)\end{array}$ & $\begin{array}{c}0.61 \\
(19.7)\end{array}$ & $\begin{array}{c}0.62 \\
(20.1)\end{array}$ & $\begin{array}{c}0.66 \\
(22.2)\end{array}$ & $\begin{array}{c}0.67 \\
(23.3)\end{array}$ & $\begin{array}{c}0.60 \\
(21.4)\end{array}$ \\
\hline \multicolumn{12}{|l|}{ Education } \\
\hline Higher & $\begin{array}{l}-0.13 \\
-(2.0)\end{array}$ & $\begin{array}{l}-0.18 \\
-(2.8)\end{array}$ & $\begin{array}{l}-0.12 \\
-(2.0)\end{array}$ & & $\begin{array}{l}-0.22 \\
-(4.0)\end{array}$ & $\begin{array}{l}-0.09 \\
-(1.2)\end{array}$ & & $\begin{array}{l}-0.21 \\
-(3.2)\end{array}$ & $\begin{array}{l}-0.16 \\
-(2.3)\end{array}$ & $\begin{array}{l}-0.20 \\
-(2.9)\end{array}$ & $\begin{array}{l}-0.24 \\
-(3.7)\end{array}$ \\
\hline Higher & $\begin{array}{l}-0.25 \\
-(5.0)\end{array}$ & $\begin{array}{l}-0.24 \\
-(4.6)\end{array}$ & $\begin{array}{l}-0.29 \\
-(5.9)\end{array}$ & $\begin{array}{l}-0.25 \\
-(5.1)\end{array}$ & $\begin{array}{l}-0.26 \\
-(6.3)\end{array}$ & $\begin{array}{l}-0.41 \\
-(7.3)\end{array}$ & & $\begin{array}{l}-0.33 \\
-(5.7)\end{array}$ & $\begin{array}{l}-0.44 \\
-(8.1)\end{array}$ & $\begin{array}{l}-0.37 \\
-(8.0)\end{array}$ & $\begin{array}{l}-0.38 \\
-(7.8)\end{array}$ \\
\hline Advan & $\begin{array}{l}0.32 \\
(5.7)\end{array}$ & $\begin{array}{l}0.34 \\
(6.3)\end{array}$ & $\begin{array}{l}0.30 \\
(5.4)\end{array}$ & $\begin{array}{l}0.17 \\
(3.2)\end{array}$ & $\begin{array}{l}0.24 \\
(5.2)\end{array}$ & $\begin{array}{l}0.25 \\
(4.5)\end{array}$ & $\begin{array}{l}0.24 \\
(4.4)\end{array}$ & $\begin{array}{l}0.19 \\
(3.6)\end{array}$ & $\begin{array}{l}0.23 \\
(4.2)\end{array}$ & $\begin{array}{l}0.17 \\
(3.4)\end{array}$ & $\begin{array}{l}0.19 \\
(3.9)\end{array}$ \\
\hline Appr & $\begin{array}{l}-0.08 \\
-(5.3)\end{array}$ & $\begin{array}{l}-0.09 \\
-(6.1)\end{array}$ & $\begin{array}{l}-0.06 \\
-(4.2)\end{array}$ & $\begin{array}{l}-0.07 \\
-(4.8)\end{array}$ & $\begin{array}{l}-0.08 \\
-(6.1)\end{array}$ & $\begin{array}{l}-0.06 \\
-(4.1)\end{array}$ & $\begin{array}{l}-0.07 \\
-(4.6)\end{array}$ & $\begin{array}{l}-0.07 \\
-(4.3)\end{array}$ & $\begin{array}{l}-0.06 \\
-(4.0)\end{array}$ & $\begin{array}{l}-0.09 \\
-(6.1)\end{array}$ & $\begin{array}{l}-0.07 \\
-(4.7)\end{array}$ \\
\hline Man & $\begin{array}{l}0.23 \\
(8.2)\end{array}$ & $\begin{array}{l}0.26 \\
(9.3)\end{array}$ & $\begin{array}{l}0.22 \\
(8.0)\end{array}$ & $\begin{array}{l}0.23 \\
(8.4)\end{array}$ & $\begin{array}{c}0.27 \\
(11.6)\end{array}$ & $\begin{array}{l}0.28 \\
(9.2)\end{array}$ & $\begin{array}{l}0.29 \\
(9.9)\end{array}$ & $\begin{array}{c}0.29 \\
(10.2)\end{array}$ & $\begin{array}{c}0.31 \\
(10.7)\end{array}$ & $\begin{array}{c}0.37 \\
(12.6)\end{array}$ & $\begin{array}{c}0.33 \\
(11.3)\end{array}$ \\
\hline & & & & & & & & & & & \\
\hline Female & $\begin{array}{c}0.45 \\
(27.0)\end{array}$ & $\begin{array}{c}0.42 \\
(25.0)\end{array}$ & $\begin{array}{c}0.38 \\
(23.0)\end{array}$ & $\begin{array}{c}0.37 \\
(22.2)\end{array}$ & $\begin{array}{c}0.39 \\
(28.9)\end{array}$ & $\begin{array}{c}0.34 \\
(20.0)\end{array}$ & $\begin{array}{c}0.31 \\
(18.3)\end{array}$ & $\begin{array}{c}0.33 \\
(19.5)\end{array}$ & $\begin{array}{c}0.33 \\
(19.9)\end{array}$ & $\begin{array}{c}0.34 \\
(20.4)\end{array}$ & $\begin{array}{c}0.33 \\
(19.4)\end{array}$ \\
\hline Male & $\begin{array}{c}-0.45 \\
-(27.0)\end{array}$ & $\begin{array}{c}-0.42 \\
-(25.0)\end{array}$ & $\begin{array}{c}-0.38 \\
-(23.0)\end{array}$ & $\begin{array}{c}-0.37 \\
-(22.2)\end{array}$ & $\begin{array}{c}-0.39 \\
-(28.9)\end{array}$ & $\begin{array}{c}-0.35 \\
-(20.0)\end{array}$ & $\begin{array}{c}-0.31 \\
-(18.3)\end{array}$ & $\begin{array}{c}-0.33 \\
-(19.5)\end{array}$ & $\begin{array}{c}-0.33 \\
-(19.9)\end{array}$ & $\begin{array}{c}-0.34 \\
-(20.4)\end{array}$ & $\begin{array}{l}-0.33 \\
-(19.4)\end{array}$ \\
\hline & & & & & & & & & & & \\
\hline Gern & $\begin{array}{l}-0.06 \\
-(7.0)\end{array}$ & $\begin{array}{l}-0.05 \\
-(5.8)\end{array}$ & $\begin{array}{l}-0.06 \\
-(6.5)\end{array}$ & $\begin{array}{l}-0.07 \\
-(7.5)\end{array}$ & $\begin{array}{l}-0.06 \\
-(9.4)\end{array}$ & $\begin{array}{l}-0.07 \\
-(6.8)\end{array}$ & $\begin{array}{l}-0.06 \\
-(6.1)\end{array}$ & $\begin{array}{l}-0.08 \\
-(7.9)\end{array}$ & $\begin{array}{l}-0.07 \\
-(7.1)\end{array}$ & $\begin{array}{l}-0.06 \\
-(6.6)\end{array}$ & $\begin{array}{l}-0.04 \\
-(4.2)\end{array}$ \\
\hline Latin part & $\begin{array}{l}0.17 \\
(7.0) \\
\end{array}$ & $\begin{array}{l}0.14 \\
(5.8) \\
\end{array}$ & $\begin{array}{l}0.15 \\
(6.5) \\
\end{array}$ & $\begin{array}{l}0.18 \\
(7.5) \\
\end{array}$ & $\begin{array}{r}0.17 \\
(9.4) \\
\end{array}$ & $\begin{array}{l}0.18 \\
(6.8) \\
\end{array}$ & $\begin{array}{l}0.16 \\
(6.1) \\
\end{array}$ & $\begin{array}{l}0.20 \\
(7.9) \\
\end{array}$ & $\begin{array}{l}0.18 \\
(7.1) \\
\end{array}$ & $\begin{array}{l}0.17 \\
(6.6) \\
\end{array}$ & $\begin{array}{l}0.11 \\
(4.2) \\
\end{array}$ \\
\hline LIKE & 3.8 & -5951.5 & 3.2 & -6740.4 & $\begin{array}{c}- \\
1435.5\end{array}$ & 5015 & -6105.0 & 01.7 & -0243.1 & $-01 / 0.2$ & -6398.2 \\
\hline \# observations & 2,910 & 13,537 & 14,379 & 14,306 & 25,056 & 12,790 & 12,864 & 12,950 & 13,929 & 13,890 & 14,483 \\
\hline
\end{tabular}

Source: Swiss Labor Force Survey; own calculations. 
Table B12: Temporary Immigrant Regressions (Transformed Coefficients - t-values in Parentheses)

\begin{tabular}{|c|c|c|c|c|c|c|c|c|c|c|c|}
\hline Variable & 1991 & 1992 & 1993 & 1994 & 1995 & 1996 & 1997 & 1998 & 1999 & 2000 & 2001 \\
\hline 1991 sample mean & $\begin{array}{c}-2.06 \\
-(48.8)\end{array}$ & $\begin{array}{c}-2.02 \\
-(39.9)\end{array}$ & $\begin{array}{c}-2.01 \\
-(37.3)\end{array}$ & $\begin{array}{c}-2.00 \\
-(34.4)\end{array}$ & $\begin{array}{c}-1.91 \\
-(41.3)\end{array}$ & $\begin{array}{c}-1.73 \\
-(30.5)\end{array}$ & $\begin{array}{c}-1.89 \\
-(31.8)\end{array}$ & $\begin{array}{c}-1.79 \\
-(34.2)\end{array}$ & $\begin{array}{c}-1.85 \\
-(37.5)\end{array}$ & $\begin{array}{c}-1.91 \\
-(31.3)\end{array}$ & $\begin{array}{c}-1.84 \\
-(34.1)\end{array}$ \\
\hline \multicolumn{12}{|l|}{ Age } \\
\hline $16-25$ & $\begin{array}{l}0.15 \\
(2.1)\end{array}$ & $\begin{array}{l}0.04 \\
(0.4)\end{array}$ & $\begin{array}{l}0.01 \\
(0.0)\end{array}$ & $\begin{array}{l}0.21 \\
(2.1)\end{array}$ & $\begin{array}{l}0.14 \\
(1.9)\end{array}$ & $\begin{array}{l}0.13 \\
(1.2)\end{array}$ & $\begin{array}{l}0.18 \\
(1.6)\end{array}$ & $\begin{array}{l}0.21 \\
(2.0)\end{array}$ & $\begin{array}{l}0.15 \\
(1.6)\end{array}$ & $\begin{array}{l}-0.06 \\
-(0.5)\end{array}$ & $\begin{array}{l}0.08 \\
(0.7)\end{array}$ \\
\hline $26-35$ & $\begin{array}{c}0.53 \\
(10.6)\end{array}$ & $\begin{array}{l}0.53 \\
(8.8)\end{array}$ & $\begin{array}{l}0.60 \\
(9.4)\end{array}$ & $\begin{array}{l}0.56 \\
(8.2)\end{array}$ & $\begin{array}{l}0.49 \\
(9.3)\end{array}$ & $\begin{array}{l}0.44 \\
(6.2)\end{array}$ & $\begin{array}{l}0.62 \\
(8.7)\end{array}$ & $\begin{array}{l}0.45 \\
(6.8)\end{array}$ & $\begin{array}{l}0.50 \\
(7.8)\end{array}$ & $\begin{array}{l}0.50 \\
(6.7)\end{array}$ & $\begin{array}{l}0.41 \\
(6.1)\end{array}$ \\
\hline $36-45$ & $\begin{array}{l}-0.01 \\
-(0.2)\end{array}$ & $\begin{array}{l}0.03 \\
(0.3)\end{array}$ & $\begin{array}{l}0.06 \\
(0.8)\end{array}$ & $\begin{array}{l}0.03 \\
(0.4)\end{array}$ & $\begin{array}{l}0.01 \\
(0.2)\end{array}$ & $\begin{array}{l}-0.01 \\
-(0.1)\end{array}$ & $\begin{array}{l}-0.01 \\
-(0.1)\end{array}$ & $\begin{array}{l}-0.02 \\
-(0.2)\end{array}$ & $\begin{array}{l}-0.03 \\
-(0.4)\end{array}$ & $\begin{array}{l}0.26 \\
(3.3)\end{array}$ & $\begin{array}{l}0.17 \\
(2.4)\end{array}$ \\
\hline $46-55$ & $\begin{array}{l}-0.35 \\
-(4.0)\end{array}$ & $\begin{array}{l}-0.24 \\
-(2.5)\end{array}$ & $\begin{array}{l}-0.22 \\
-(2.0)\end{array}$ & $\begin{array}{l}-0.25 \\
-(2.2)\end{array}$ & $\begin{array}{l}-0.39 \\
-(4.0)\end{array}$ & $\begin{array}{l}-0.30 \\
-(2.6)\end{array}$ & $\begin{array}{l}-0.56 \\
-(4.1)\end{array}$ & $\begin{array}{l}-0.47 \\
-(4.2)\end{array}$ & $\begin{array}{l}-0.45 \\
-(4.4)\end{array}$ & $\begin{array}{l}-0.38 \\
-(2.8)\end{array}$ & $\begin{array}{l}-0.32 \\
-(2.9)\end{array}$ \\
\hline $56-65$ & $\begin{array}{l}-0.86 \\
-(5.2)\end{array}$ & $\begin{array}{l}-0.93 \\
-(4.7)\end{array}$ & $\begin{array}{l}-1.14 \\
-(5.4)\end{array}$ & $\begin{array}{l}-1.30 \\
-(4.9)\end{array}$ & $\begin{array}{l}-0.72 \\
-(4.3)\end{array}$ & $\begin{array}{l}-0.70 \\
-(2.9)\end{array}$ & $\begin{array}{l}-0.73 \\
-(2.9)\end{array}$ & $\begin{array}{l}-0.57 \\
-(2.6)\end{array}$ & $\begin{array}{l}-0.57 \\
-(3.0)\end{array}$ & $\begin{array}{l}-0.91 \\
-(3.8)\end{array}$ & $\begin{array}{l}-0.88 \\
-(4.5)\end{array}$ \\
\hline \multicolumn{12}{|l|}{ Education } \\
\hline Higher & $\begin{array}{l}0.72 \\
(9.3)\end{array}$ & $\begin{array}{l}0.77 \\
(8.8)\end{array}$ & $\begin{array}{l}0.51 \\
(5.1)\end{array}$ & $\begin{array}{l}0.47 \\
(4.3)\end{array}$ & $\begin{array}{l}0.69 \\
(8.4)\end{array}$ & $\begin{array}{l}0.74 \\
(6.8)\end{array}$ & $\begin{array}{l}0.74 \\
(7.4)\end{array}$ & $\begin{array}{l}0.75 \\
(7.5)\end{array}$ & $\begin{array}{l}0.75 \\
(8.2)\end{array}$ & $\begin{array}{l}0.76 \\
(7.8)\end{array}$ & $\begin{array}{l}0.64 \\
(6.9)\end{array}$ \\
\hline Higher vocational & $\begin{array}{l}-0.08 \\
-(0.9)\end{array}$ & $\begin{array}{l}-0.24 \\
-(2.1)\end{array}$ & $\begin{array}{l}-0.11 \\
-(1.0)\end{array}$ & $\begin{array}{l}0.01 \\
(0.1)\end{array}$ & $\begin{array}{l}-0.12 \\
-(1.1)\end{array}$ & $\begin{array}{l}-0.07 \\
-(0.5)\end{array}$ & $\begin{array}{l}0.05 \\
(0.4)\end{array}$ & $\begin{array}{l}0.02 \\
(0.2)\end{array}$ & $\begin{array}{l}-0.05 \\
-(0.4)\end{array}$ & $\begin{array}{l}-0.52 \\
-(3.4)\end{array}$ & $\begin{array}{l}-0.33 \\
-(2.3)\end{array}$ \\
\hline Advanced high sch. & $\begin{array}{l}0.11 \\
(1.1)\end{array}$ & $\begin{array}{l}0.47 \\
(4.3)\end{array}$ & $\begin{array}{l}0.38 \\
(3.0)\end{array}$ & $\begin{array}{l}0.35 \\
(2.8)\end{array}$ & $\begin{array}{l}0.27 \\
(2.6)\end{array}$ & $\begin{array}{l}0.03 \\
(0.2)\end{array}$ & $\begin{array}{l}0.28 \\
(2.0)\end{array}$ & $\begin{array}{l}0.25 \\
(1.9)\end{array}$ & $\begin{array}{l}0.20 \\
(1.5)\end{array}$ & $\begin{array}{l}-0.08 \\
-(0.6)\end{array}$ & $\begin{array}{l}0.30 \\
(2.3)\end{array}$ \\
\hline Apprenticeship & $\begin{array}{l}-0.22 \\
-(7.1)\end{array}$ & $\begin{array}{l}-0.25 \\
-(6.5)\end{array}$ & $\begin{array}{l}-0.21 \\
-(5.3)\end{array}$ & $\begin{array}{l}-0.22 \\
-(5.3)\end{array}$ & $\begin{array}{l}-0.24 \\
-(7.3)\end{array}$ & $\begin{array}{l}-0.16 \\
-(3.6)\end{array}$ & $\begin{array}{l}-0.19 \\
-(4.5)\end{array}$ & $\begin{array}{l}-0.19 \\
-(4.5)\end{array}$ & $\begin{array}{l}-0.23 \\
-(5.7)\end{array}$ & $\begin{array}{l}-0.14 \\
-(3.0)\end{array}$ & $\begin{array}{l}-0.22 \\
-(4.9)\end{array}$ \\
\hline Mandatory or less & $\begin{array}{l}0.36 \\
(5.9)\end{array}$ & $\begin{array}{l}0.40 \\
(5.3)\end{array}$ & $\begin{array}{l}0.35 \\
(4.4)\end{array}$ & $\begin{array}{l}0.30 \\
(3.8)\end{array}$ & $\begin{array}{l}0.38 \\
(6.4)\end{array}$ & $\begin{array}{l}0.20 \\
(2.0)\end{array}$ & $\begin{array}{l}0.15 \\
(1.6)\end{array}$ & $\begin{array}{l}0.16 \\
(1.6)\end{array}$ & $\begin{array}{l}0.31 \\
(3.7)\end{array}$ & $\begin{array}{l}0.43 \\
(4.5)\end{array}$ & $\begin{array}{l}0.46 \\
(5.3)\end{array}$ \\
\hline Gender & & & & & & & & & & & \\
\hline Female & $\begin{array}{l}-0.10 \\
-(2.5)\end{array}$ & $\begin{array}{l}-0.16 \\
-(3.3)\end{array}$ & $\begin{array}{l}-0.20 \\
-(4.3)\end{array}$ & $\begin{array}{l}-0.08 \\
-(1.6)\end{array}$ & $\begin{array}{l}-0.06 \\
-(1.5)\end{array}$ & $\begin{array}{l}0.02 \\
(0.4)\end{array}$ & $\begin{array}{l}0.08 \\
(1.6)\end{array}$ & $\begin{array}{l}0.06 \\
(1.2)\end{array}$ & $\begin{array}{l}-0.04 \\
-(0.9)\end{array}$ & $\begin{array}{l}-0.02 \\
-(0.5)\end{array}$ & $\begin{array}{l}0.00 \\
(0.1)\end{array}$ \\
\hline Male & $\begin{array}{l}0.07 \\
(2.5)\end{array}$ & $\begin{array}{l}0.12 \\
(3.3)\end{array}$ & $\begin{array}{l}0.15 \\
(4.3)\end{array}$ & $\begin{array}{l}0.06 \\
(1.6)\end{array}$ & $\begin{array}{l}0.04 \\
(1.5)\end{array}$ & $\begin{array}{l}-0.02 \\
-(0.4)\end{array}$ & $\begin{array}{l}-0.06 \\
-(1.6)\end{array}$ & $\begin{array}{l}-0.04 \\
-(1.2)\end{array}$ & $\begin{array}{l}0.03 \\
(0.9)\end{array}$ & $\begin{array}{l}0.02 \\
(0.5)\end{array}$ & $\begin{array}{c}0.00 \\
-(0.1)\end{array}$ \\
\hline Kegion oj Kes & & & & & & & & & & & \\
\hline German part & $\begin{array}{l}-0.03 \\
-(1.9)\end{array}$ & $\begin{array}{c}0.00 \\
-(0.1)\end{array}$ & $\begin{array}{l}-0.05 \\
-(2.5)\end{array}$ & $\begin{array}{l}-0.04 \\
-(1.9)\end{array}$ & $\begin{array}{l}-0.07 \\
-(4.3)\end{array}$ & $\begin{array}{l}-0.07 \\
-(2.7)\end{array}$ & $\begin{array}{l}-0.06 \\
-(2.6)\end{array}$ & $\begin{array}{l}-0.08 \\
-(3.2)\end{array}$ & $\begin{array}{l}-0.08 \\
-(3.6)\end{array}$ & $\begin{array}{l}-0.05 \\
-(2.2)\end{array}$ & $\begin{array}{l}-0.05 \\
-(1.9)\end{array}$ \\
\hline Latin part & $\begin{array}{l}0.09 \\
(1.9) \\
\end{array}$ & $\begin{array}{l}0.00 \\
(0.1)\end{array}$ & $\begin{array}{l}0.15 \\
(2.5) \\
\end{array}$ & $\begin{array}{l}0.11 \\
(1.9)\end{array}$ & $\begin{array}{l}0.20 \\
(4.3) \\
\end{array}$ & $\begin{array}{l}0.20 \\
(2.7) \\
\end{array}$ & $\begin{array}{l}0.18 \\
(2.6)\end{array}$ & $\begin{array}{l}0.22 \\
(3.2) \\
\end{array}$ & $\begin{array}{l}0.23 \\
(3.6)\end{array}$ & $\begin{array}{l}0.15 \\
(2.2) \\
\end{array}$ & $\begin{array}{l}0.13 \\
(1.9) \\
\end{array}$ \\
\hline $\begin{array}{l}\text { Log Likelihood } \\
\text { \# observations }\end{array}$ & $\begin{array}{r}-1321.7 \\
10,261 \\
\end{array}$ & $\begin{array}{c}-1549.8 \\
10,895 \\
\end{array}$ & $\begin{array}{c}-1698.5 \\
11,525 \\
\end{array}$ & $\begin{array}{c}-1700.2 \\
11,395 \\
\end{array}$ & $\begin{array}{c}-3232.7 \\
19,913 \\
\end{array}$ & $\begin{array}{c}-2069.1 \\
10,256 \\
\end{array}$ & $\begin{array}{c}-1806.1 \\
10,324 \\
\end{array}$ & $\begin{array}{c}-1991.8 \\
10,503 \\
\end{array}$ & $\begin{array}{c}-2013.6 \\
11,355 \\
\end{array}$ & $\begin{array}{c}-1877.6 \\
11,265 \\
\end{array}$ & $\begin{array}{r}-2113.1 \\
11,818 \\
\end{array}$ \\
\hline
\end{tabular}

Source: Swiss Labor Force Survey; own calculations. 